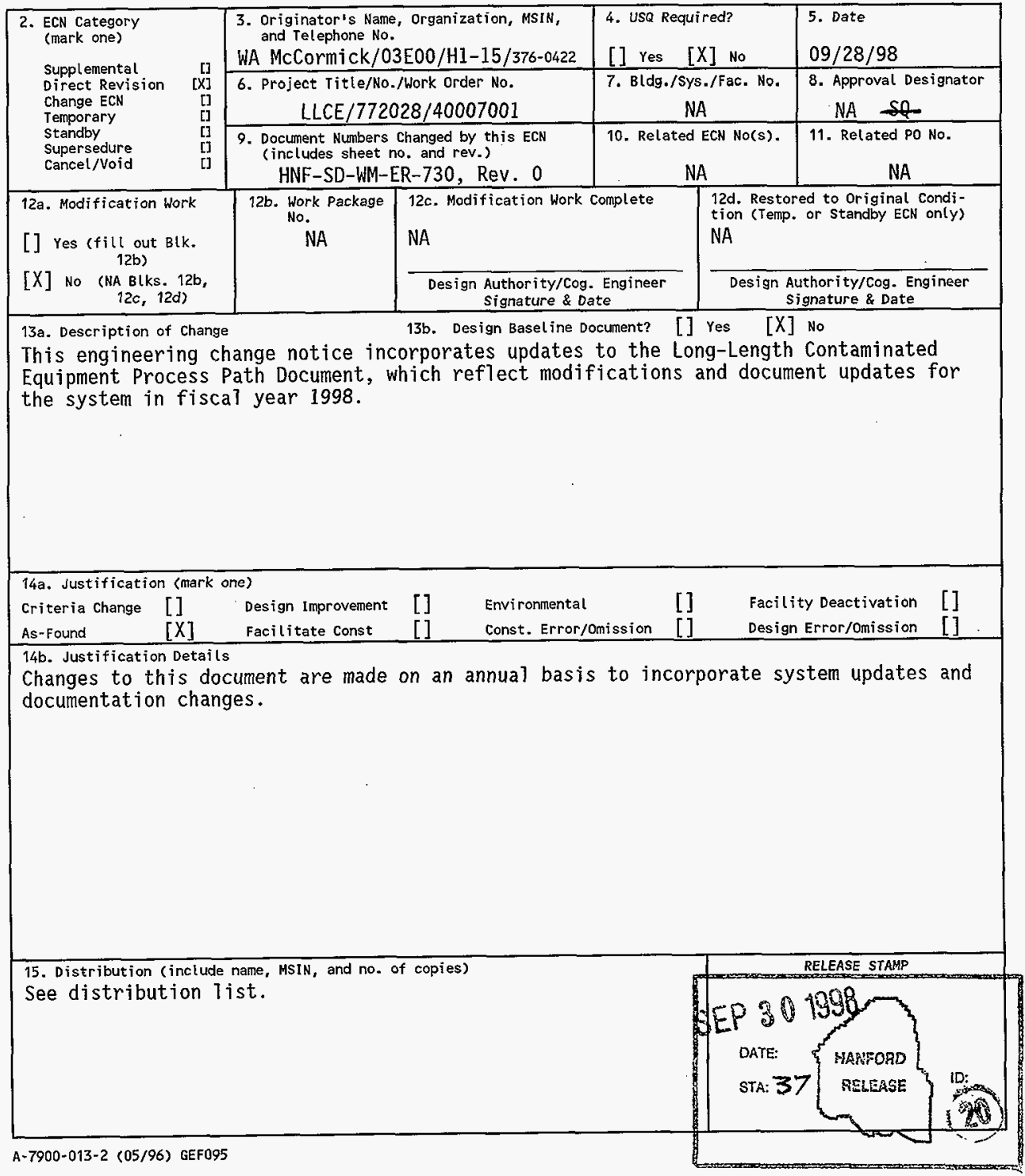




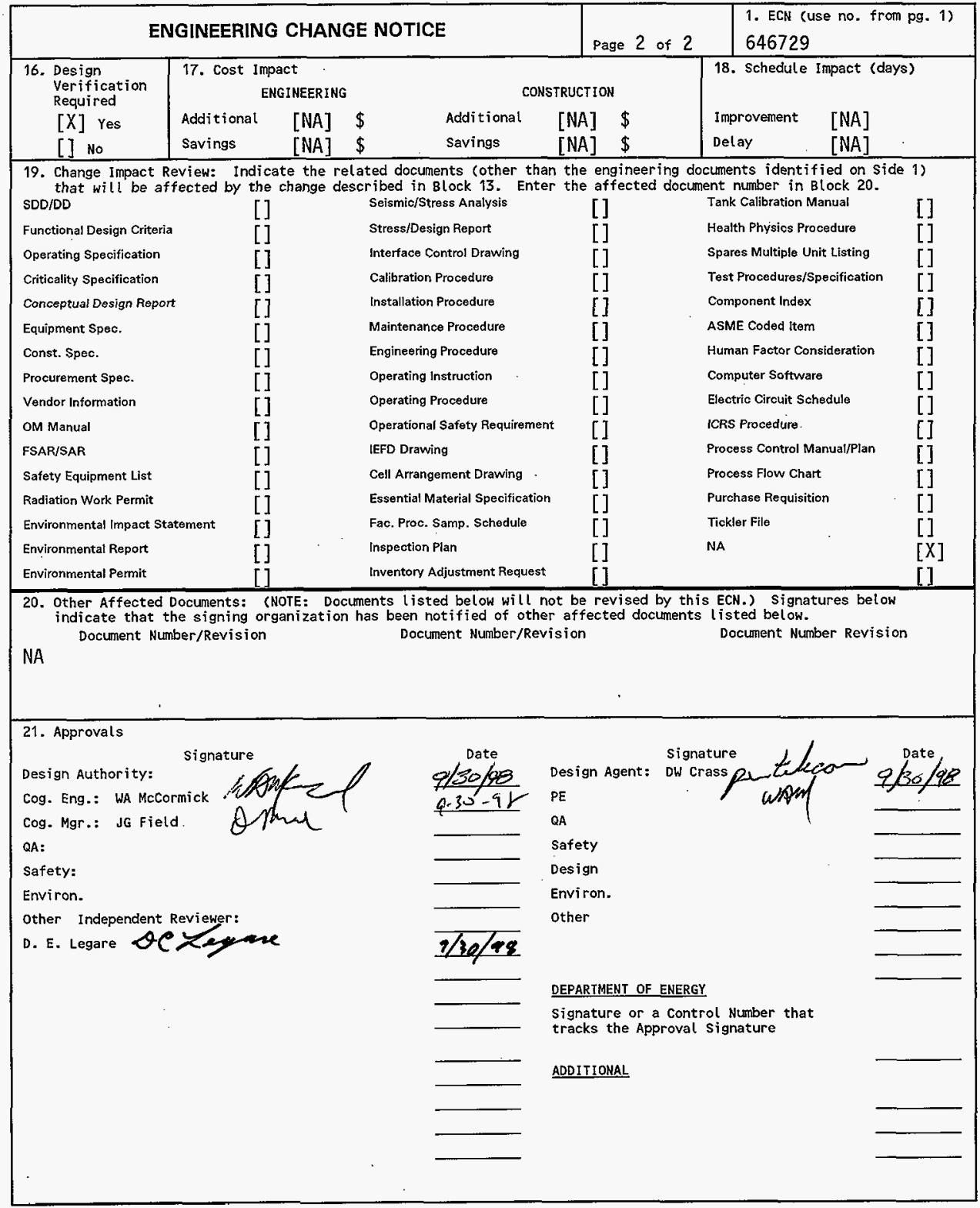




\title{
Long-Length Contaminated Equipment Disposal Process Path Document
}

\author{
W. A. McCormick
}

Waste Management Federal Services, Inc., Northwest Operations, Richland, WA 99352

for Fluor Daniel Hanford, Inc.

U.S. Department of Energy Contract DE-AC06-87RL10930

$\begin{array}{lll}\text { EDT/ECN: } & \text { ECN } 646729 & \text { UC: } 513 \\ \text { Org Code: } & \text { O3E00 } & \begin{array}{l}\text { Charge Code: D6309 Task Order: GS080003 } \\ \text { Project: 772028 Crosswalk 40-007-001 }\end{array} \\ \text { B\&R Code: } & \text { EW3130010 } & \text { Total Pages: 86 }\end{array}$

Key Words: LLCE, Disposal Process, Process Path Document

Abstract: The first objective of the LLCE Process Path Document is to guide future users of this system on how to accomplish the cradie-tograve process for the disposal of long-length equipment. Information will be provided describing the function and approach to each step in the process. Pertinent documentation, prerequisites, drawings, procedures, hardware, software, and key interfacing organizations wiil be identified. The second objective is related to the decision to lay up the program until funding is made available to complete it or until a need arises due to failure of an important component in a waste tank. To this end, the document will identify work remaining to be completed for each step of the process and open items or issues that remain to be resolved.

TRADEMARK DISCLAIMER. Reference herein to any specific commercial product, process, or service by trade name, trademark, manufacturer, or otherwise, does not necessarily constitute or imply its endorsement, recommendation, or favoring by the United States Government or any agency thereof or its contractors or subcontractors.

Printed in the United States of America. To obtain copies of this document, contact: WHC/BCS Document Control Services, P.O. Box 1970, Mailstop H6-08, Richland WA 99352, Phone (509) 372-2420; Fax (509) 376-4989.

Ranin Aesadal $9-30-98$

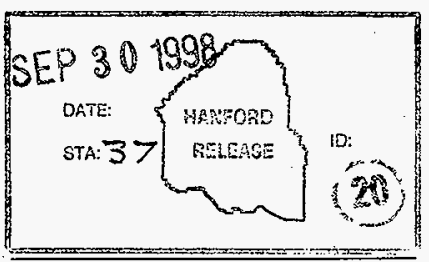

Release Stamp 


\section{RECORD OF REVISION}

\section{(1) Document Number

(2) Title

Long-Length Contaminated Equipment Disposal Process Path Document

CHANGE CONTROL RECORD

\begin{tabular}{|c|l|}
\hline \multirow{2}{*}{ (3) Revision } & (4) Description of Change - Replace, Add, and Delete Pages \\
\cline { 2 - 3 } & (7) EDT 621469, dated June 26, 1997 \\
\hline 1 RS & $\begin{array}{l}\text { Complete revision. Replace a]1 pages. Per } \\
\text { ECN 646729. }\end{array}$ \\
\hline
\end{tabular}

\begin{tabular}{|l|l|}
\hline \multicolumn{2}{|c|}{ Authprized for Release } \\
\hline (5) cog. Engr) & (6) cog. Mgr. Date \\
\hline
\end{tabular}




\title{
LONG-LENGTH CONTAMINATED EQUIPMENT DISPOSAL PROCESS PATH DOCUMENT
}

\author{
Engineering Task Number ETN-94-0054A
}

Prepared for

\section{WASTE MANAGEMENT FEDERAL SERVICES, INC. Agreement No. A52770, Task Order 001 \\ Report No. 987201-001, Rev. 1}

(Previous revision prepared for Fluor Daniel Northwest under

Purchase Order MAA-SLB-336070, Task A96-147

Report No. 961 147-001, Revision 0)

September 1998

Prepared by

\section{ARES CORPORATION}

636 Jadwin Avenue Suite B

Richland, Washington 99352 


\title{
LONG-LENGTH CONTAMINATED EQUIPMENT DISPOSAL PROCESS PATH DOCUMENT
}

\author{
Engineering Task Number ETN-94-0054A
}

Prepared for

\section{WASTE MANAGEMENT FEDERAL SERVICES, INC. Agreement No. A52770, Task Order 001 Report No. 987201-001, Rev. 1}

(Previous revision prepared for Fluor Daniel Northwest under Purchase Order MAA-SLB-336070, Task A96-147

Report No. 961147-001, Revision 0)

September 1998

Prepared by: Stephen D. Riesenweber Steven Weaver Approved by:

Robert L. Fritz

Date: $9-29 \cdot 98$ 


\section{TABLE OF CONTENTS}

$1.0 \quad$ INTRODUCTION $\ldots \ldots \ldots \ldots \ldots \ldots \ldots \ldots \ldots \ldots \ldots \ldots \ldots \ldots \ldots \ldots \ldots \ldots \ldots \ldots$

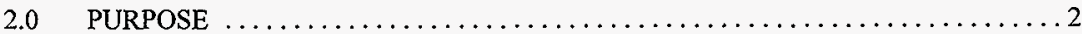

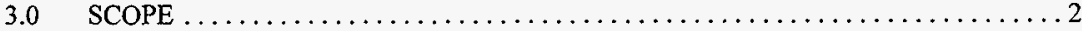

4.0 OVERALL PROCESS DESCRIPTION $\ldots \ldots \ldots \ldots \ldots \ldots \ldots \ldots \ldots \ldots \ldots \ldots$

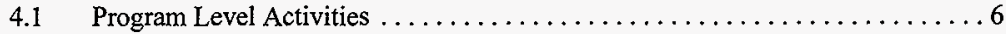

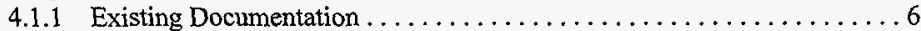

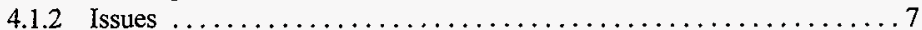

4.1.3 Remaining Work $\ldots \ldots \ldots \ldots \ldots \ldots \ldots \ldots \ldots \ldots \ldots$

5.0 DETAILED LLCE PROCESS $\ldots \ldots \ldots \ldots \ldots \ldots \ldots \ldots \ldots \ldots \ldots \ldots \ldots \ldots$

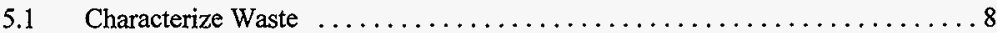

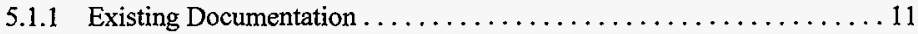

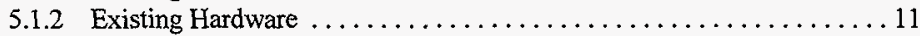

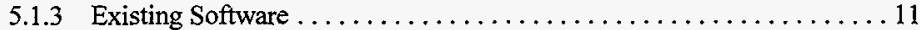

5.1.4 User Information Needed to Accomplish Task $\ldots \ldots \ldots \ldots \ldots \ldots \ldots 12$

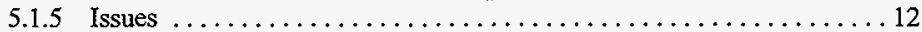

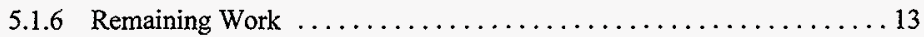

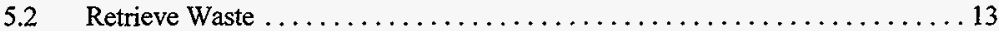

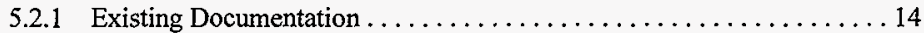

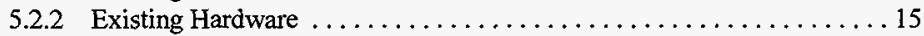

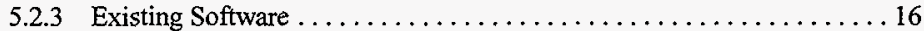

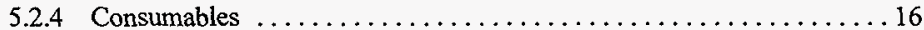

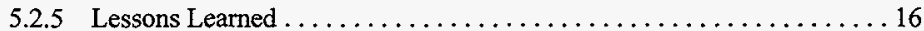

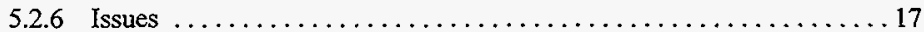

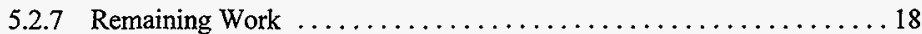

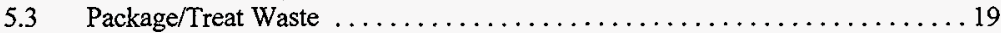

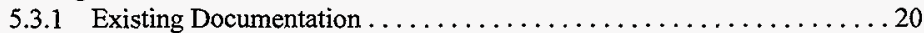

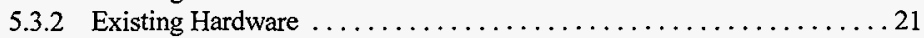

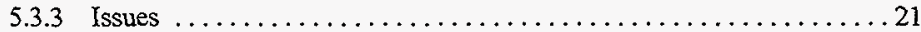

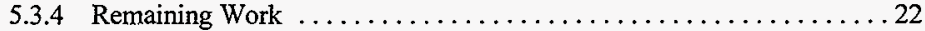

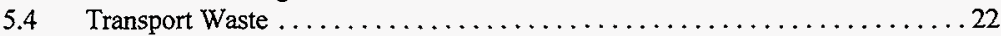

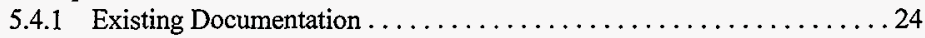

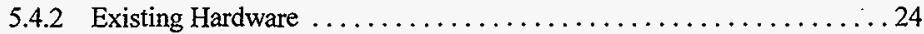

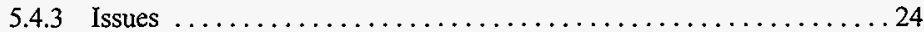




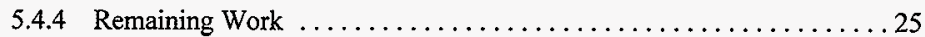

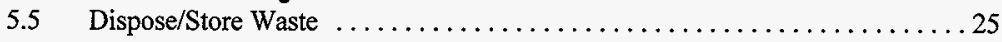

5.5.1 Existing Documentation ............................ 27

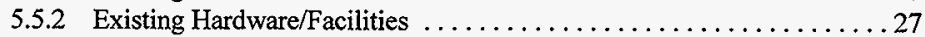

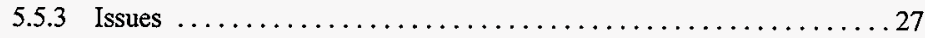

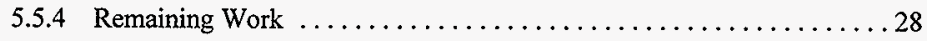

\section{APPENDICES}

\section{Appendix A}

Original WesTIP Process Map $\ldots \ldots \ldots \ldots \ldots \ldots \ldots \ldots \ldots \ldots \ldots \ldots \ldots \ldots \ldots \ldots$ Appendix B

Appendix C

Appendix D

Drawing Traceability Example Appendix E

LLCE Program Summary of Remaining Work

Procedure Matrix

Appendix F

Characterization Computer Program Example F-1 


\section{FIGURES}

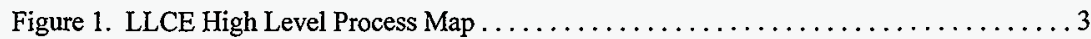

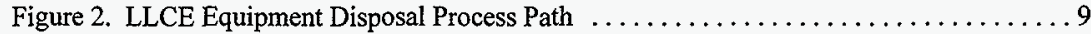

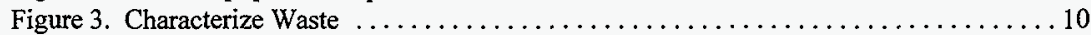

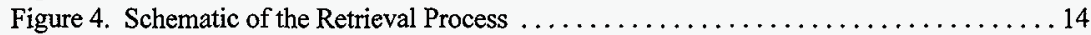

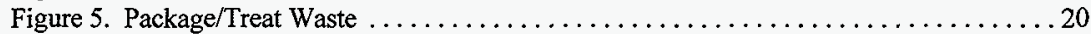

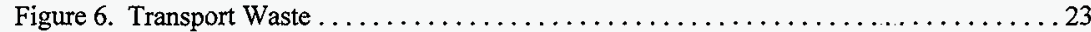

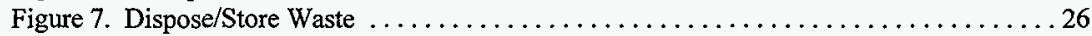

\section{TRADEMARKS}

WesTIP(B) A registered trademark of Westinghouse Electric Corporation, Pittsburgh, PA. 


\section{ACRONYMS}

CCTV Closed-Circuit Television

CWC Central Waste Complex

DCRT Double-Contained Receiver Tanks

DST Double-Shell Tank

EPA Environmental Protection Agency

FRA Flexible Receiver Apparatus

HEPA High-Efficiency Particulate Air

LLCE Long-Length Contaminated Equipment

NOC Notice of Construction

QT Qualification Testing

RCRA Resource Conservation Recovery Act

RMW Radioactive Mixed Waste

SARP Safety Analysis Report for Packaging

SEP Safety Evaluation for Packaging

SST Single-Shell Tank

TRUM Transuranic Mixed Waste

TWRS Tank Waste Remediation System

USQ Unreviewed Safety Question

VDTT Viscosity Density Temperature Tree 


\subsection{INTRODUCTION}

Within the 200 Area Tank Farms at the Hanford Nuclear Reservation, there are more than 177 underground tanks used for the storage of high-level and low-level radioactive mixed waste (RMW). The majority of this waste was generated during World War II and the Cold War period as a part of the nuclear weapons production effort. The majority of these tanks range in capacity from 530,000 to $1,160,000$ gallons. Of these, the earliest built are 149 single-walled tanks called single-shell tanks (SSTs), which are no longer actively used; most of these tanks have been stabilized by pumping the free liquids from the tanks and isolating all sources of liquid input. Twenty-eight double-shell tanks (DSTs) containing liquid waste provide the bulk of the current active storage capacity. The current mission of the Tank Waste Remediation System (TWRS) is to safely store, retrieve, and transport the waste in preparation for vitrification, and finally, decommission the tanks and miscellaneous equipment and facilities.

Since the tanks are underground, equipment such as pumps, air lances, and monitoring equipment is installed from above through risers in the top of the tank. DSTs generally range in height from 45 to 50 feet and are buried a minimum of 10 feet below grade. This results in the majority of such equipment being greater than 12 feet in length (called "long-length equipment"). There are approximately 1,300 long-length pieces of equipment currently installed in DSTs and SSTs; many more will be installed during the remaining life of Tank Farms to support the mission described above.

At some point during the operation, remediation, and/or decommissioning of Tank Farms, many of these items will need to be removed from the tanks either to provide access to the tank through one of the limited number of existing risers or to replace failed or obsolete equipment. In either case, once removed, this equipment will require disposal. With the advent of the 1992 Environmental Protection Agency (EPA) Debris Rule, the past practice of rinsing, plastic wrapping, and land disposal of mixed waste contaminated equipment as non-mixed low-level waste is no longer possible. Under the EPA Debris Rule, contaminated equipment must be disposed of as RMW. This involves treatment using one of the treatment technologies listed in 40 CFR 268.45 prior to land disposal or treatment to exit Resource Conservation Recovery Act (RCRA) requirements.

Costs to comply with these new requirements have been extremely high since no infrastructure exists to accomplish the task. Actual costs resulting from the removal, packaging, and storage of three air lances from Tank 101-SY in late 1992, were in excess of $\$ 1,000,000$ per lance; additional costs for the treatment and disposal of this equipment will increase this total to an estimated $\$ 1,700,000$. Several subsequent projects developing limited-use engineered approaches to retrieval and disposal have experienced similar expensive hurdles to cost-effective retrieval, treatment, and disposal. As a result, several facilitated WesTIP $\otimes$ workshops were held 
to formulate the basis for a standardized cradle-to-grave process for the disposal of Long-Length Contaminated Equipment (termed LLCE). The LLCE Program is utilizing lessons learned and much of the equipment from preceding disposal initiatives to produce the equipment and infrastructure needed for a cost-effective and standardized removal and disposal process.

The LLCE process has been defined and agreed to by both the generator and disposal entities with the encouragement and support of the U.S. Department of Energy and the Washington State Department of Ecology. The design for all primary components of the LLCE system has been compieted and the major reusable hardware items have been procured or fabricated.

\subsection{PURPOSE}

The LLCE Program approach to long-length equipment disposal has evolved over time as a result of such things as clarification of regulatory requirements, cost/benefit trade studies, lessons learned from other efforts, organizational changes, and changes in the treatment/disposal approach by the disposal agent. Furthermore, a considerable amount of equipment has been developed and hundreds of drawings generated for the various programs and projects working on case specific LLCE disposal efforts. Some of this information is being incorporated into the generic LLCE system and some is not. This continual evolution has resulted in a confusing array of requirements, drawings, procedures, and equipment. The purpose of this document is twofold:

1) The first objective of the LLCE Process Path Document is to guide future users of this system on how to accomplish the cradle-to-grave process for the disposal of long-length equipment. Information is provided describing the function and approach to each step in the process. Pertinent documentation, prerequisites, drawings, procedures, hardware, software, and key interfacing organizations are identified.

2) The second objective is related to the decision to lay up the program until the first field application of this system. This document will identify work remaining to be completed for each step of the process and open items or issues which remain to be resolved.

\subsection{SCOPE}

The LLCE disposal system is intended to establish the entire process from the point that a need for removal of equipment arises to the time when a long-length item is ready for final disposal. This document encompasses this entire span (cradle-to-grave). Since plans and requirements often change with time, a certain amount of verification as to the current applicability of the information contained herein will be required on the part of the user. 
Specific procedures and work activities performed by the Solid Waste Disposal organization of Waste Management Hanford will not be contained in this document since they remain to be defined and are beyond the control of Tank Farms management.

\subsection{OVERALL PROCESS DESCRIPTION}

The LLCE process can be broken into the five high-level steps depicted in Figure 1. These steps include Characterize Waste, Retrieve Waste, Package/Treat Waste, Transport Waste, and Dispose/Store Waste. A brief overall description of the LLCE process is provided below. Detailed descriptions of the process steps, equipment, reference information, issues, and remaining work may be found in Section 5.0.
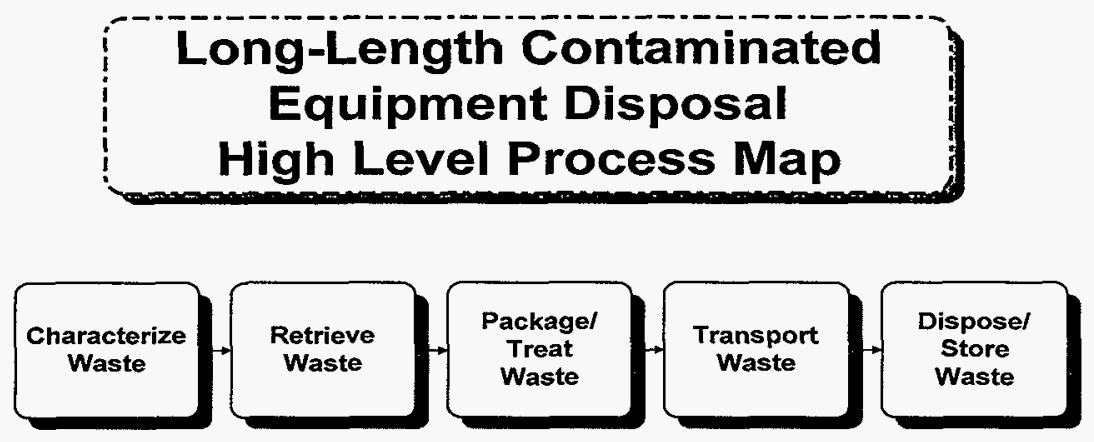

Figure 1. LLCE High Level Process Map

The original WesTIPB workshop resulted in the process map contained in Appendix A. It represents the first systematic look at the steps required to accomplish a limited-use engineered retrieval and disposal effort. The resulting estimated costs were $\$ 1.2$ million per item for retrieval to storage with an elapsed time of 92.7 weeks. Treatment and disposal costs were not included at this time because a clear approach to disposal was not yet apparent. Appendix B contains the final WesTIPß revision of the process map resulting from the last workshop which took place on January 11-12, 1995. Figure 2, contained in Section 5.0, depicts the final detailed 
process map that has resulted from the development of hardware and software in the ensuing months. This map forms the basis of this document and the LLCE process as it currently stands.

Prior to mobilization of any equipment, preliminary characterization of the waste likely to be found within the LLCE will be performed. The most recent tank waste characterization information along with the physical attributes of the equipment to be removed will be input and processed in the PC-based LLCEDATA Program. This program will identify the proper burial container and Flexible Receiver Apparatus (FRA). The program will also prepare a data file which will be used in conjunction with radiological assay data gathered during equipment retrieval to confirm that the waste falls within the bounds established in the LLCE Waste Certification Summary.

Retrieval of LLCE is accomplished using a mobile crane and the FRA, originally designed for specific locations and equipment in Tank 101-AZ in support of Project W-151, "Tank 101-AZ Waste Retrieval System". This system provides a means of remotely retrieving equipment from a riser into a flexible Herculite bag which is sealed and "double bagged" on the bottom end. The FRA also washes the equipment externally with a 3,000 psi hot water spray and performs a gamma assay along the length of the equipment as it is being removed. Information gathered from the assay is used during the Packaging/Treatment step to verify the waste classification of the equipment.

Two sizes of FRAs have been built. The 4/6-inch device is for use on small risers containing such equipment as thermocouple trees and instrumentation trees. The other 42 -inch unit is for use on larger risers contained in pits that hold such equipment as transfer and mixer pumps.

The LLCE Program has made the FRA system generically useful by designing platforms and adapters which conform to the varying physical configurations found at the different tank farms and Double-Contained Receiver Tanks (DCRTs). An additional enhancement is the addition of provisions in the flexible bags to support internal flush of waste equipment, such as transfer pumps during retrieval, in order to reduce contamination levels.

A receiver trailer has been designed and built for the LLCE Program. This trailer will be positioned in the Tank Farm adjacent to the crane and FRA. Its function is to receive the bagged equipment in a half-shell skid assembly while it is still in a vertical position, transition it safely and stably to a horizontal position, and act as the vehicle to move the equipment to a location nearby for packaging.

Once waste equipment is transitioned to horizontal, the receiver trailer is moved to a nearby packaging/staging area where the LLCE Transport Trailer is located with a burial container secured in place. Nine container sizes have been identified to contain at least 98 percent of all 
LLCE. Eight of the nine sizes of containers have been designed and tested. The two trailers are remotely aligned and a remote tug assembly moves the equipment and skid into the polyethylene container. The container lid is then positioned and welded in place using electrical heating elements incorporated into the container lid.

The data file output from the FRA gamma assay equipment during retrieval is input with the LLCEDATA computer program output data into the LLCECALC Program. This program analyzes the information to verify and ensure compliance with transportation and disposal requirements specified in the Safety Analysis Report for Packaging (SARP), and the Waste Certification Summary.

As long as the LLCECALC Program verifies that the waste is not suspect transuranic mixed waste (TRUM) and that excess hydrogen gas will not be generated, the waste item can be treated per RCRA requirements for disposal in the mixed waste landfill trenches located in the 200 West Area. "Macro-encapsulation" has been determined to be the most cost effective treatment approach. This process involves filling the polyethylene container with low-density perlite grout to completely encase the LLCE. Then the grout and vent ports are sealed and tested and the package is ready for shipment to the mixed-waste trench.

The transport trailer holding the disposal container has been specially designed to accommodate the heavy load associated with a grout filled container and to maneuver through the Hanford Site roads. This is accomplished through the use of multiple axles with steerable bogey's on the rearend.

A SARP has been released for the family of containers that provides a single safety analysis for the transport of LLCE waste containers. The SARP bounds the waste that may be transported for routine operations. If contamination levels or constituents are found to exceed the bounding limits of the SARP, an Engineering Change Notice will be written against this document or a single use Safety Evaluation for Packaging (SEP) can be generated prior to shipment. These documents place vehicle speed, environmental, and administrative controls on the transport process.

The destination for transport is dependant upon the results of the LLCECALC Program. If the waste turns out to be suspect TRUM, or calculated hydrogen generation rates are too high, it cannot be disposed of in the mixed-waste trench. In this case, it will be taken to T-Plant for storage and eventual alternative treatment. Less than five percent of the equipment removed is expected to have this classification. Equipment that is determined to not be TRUM will be transported directly to the mixed-waste trench. 
The majority of the waste will be off-loaded into one of the two existing mixed-waste trenches. The trenches, though complete, have not yet been activated for a disposal function. The current approach is to store waste in the trenches until the disposal function is authorized. This approach will require chocking, fire protection, and monitoring arrangements for the equipment containers similar to what will be needed in the Central Waste Complex (CWC). In some cases, temporary shielding may be required. Once the trenches are transitioned to a disposal role, the equipment can be simply off-loaded and covered with backfill.

Figure 2 in Section 5.0 provides an overall perspective of the LLCE process. This figure may be used to guide the approximate order that events should take place during LLCE retrieval and disposal. It should be noted that all sub-elements of the high-level steps, Figure 1, do not occur sequentially. This diagram is intended to clarify the overall relation of activities.

\subsection{Program Level Activities}

Integration and cooperation has taken place between the various groups and projects that have had and will have a need to remove and dispose of long-length equipment. Examples of those having input include: Tank Farms Operations, Waste Management Hanford, Project W-151, Project W-320, "241-C-106 Sluicing", Project W-211, "Initial Tank Retrieval System", Safety Programs (101-SY), and the CWC. In order for the process to work effectively, early and close communication must be maintained between the engineer(s) associated with the above groups.

A complex series of drawings exists to support the various FRA pit and riser configurations found in the Tank Farms. Drawing H-2-79190 provides the most complete assembly drawings available for the retrieval system. Drawing H-2-827806 is the drawing index for the burial container assemblies. Drawing H-2-827806 provides the LLCE drawing index.

A test case to remove a transfer pump from Tank 104-AW was performed in order to assure that the drawings provide sufficient traceability to support proper component selection and assembly. This test showed that it was possible to identify all necessary components. The results of this test are contained in Appendix $C$.

\subsubsection{Existing Documentation}

- $\quad$ LLCE Work Plan, WHC-SD-WM-WP-215, Rev. 1.

- LLCE Program Level Functions and Requirements, WHC-SD-WM-022, Rev. 0.

- Comparison Report on Method for Disposal of Long-Length Contaminated Equipment, ARES Report No. 951122-001. 
- WesTIP@ Workshop Results (multiple sessions)

- WesTIP $@$ Workshop Charts for Tank Farm Disposal of Long-Length

Contaminated Equipment, EDT 141849

- WesTIP® Workshop, Tank Farm Disposal of Long-Length Contaminated Equipment, WHC-SD-WM-ER-303, Rev 0

- WesTIP@ Workshop, Tank Farm Disposal of Long-Length Contaminated Equipment, WHC-SD-WM-ER-353, Rev. 0

- WesTIP@ Workshop, Tank Farm Disposal of Long-Length Contaminated Equipment, WHC-SD-WM-ER-433, Rev. 0

- Safety Analysis Report for Packaging (Onsite) Long-Length Contaminated Equipment Transport System, HNF-SD-TP-SARP-013, Rev. 0.

- Authorization Basis Assessment of Removal, Packaging, and Transportation of Long-Length Contaminated Equipment, HNF-2311, Rev. 0.

- Unreviewed Safety Question Screening, Long-Length Contaminated Equipment Transport System, USQ Tracking No. TF-98-0550, Rev.0.

\subsubsection{Issues}

- A system for tracking and controlling which equipment has been fabricated/ procured and where it is stored does not exist. Most equipment is currently distributed between the Cold Test Facility, located on Route 3, and the fenced equipment lay down yard adjacent to Building 2704-HV.

\subsubsection{Remaining Work}

At this point, several tasks remain to be completed to finalize the LLCE Program. These tasks fall in the realm of limited design, fabrication, testing, configuration management, and the procurement of spare "consumable" equipment. A brief description of remaining work is found in each of the following sections and is summarized in Appendix D.

Following are the remaining tasks that best fit into a program level description:

- Overall system Qualification Testing (QT) must be completed to assure proper operation of equipment in conjunction with interfacing elements prior to use in a contaminated environment. This task also includes preparation of the Cold Test Facility to support QT. 
- Overall system operator training must be performed prior to the first tank farm use. Due to the movement of personnel and the likely span of time between retrieval activities, some training will be required prior to each equipment removal.

- Completion of TWRS Maintenance and Operating Procedures is needed to assure that the equipment can be safely operated and adequately maintained. Higher level "operating instructions" have been prepared which will aid in procedure preparation. Appendix E contains the LLCE Disposal System Procedure Matrix which identifies the specific procedures needed and the current status of their development.

- A limited number of consumable spares should be identified and procured for use in unanticipated situations.

- A standardized system for LLCE Program equipment tracking and storage must be established.

\subsection{DETAILED LLCE PROCESS}

The following sections provide a detailed description of the primary elements of the disposal process. Figure 2 depicts this process.

\subsection{Characterize Waste}

Figure 3 depicts the activities that take place during the "Characterize Waste" process step.

Characterization of the waste is needed for three reasons: 1) physical parameters, including weight and dimensions are needed to select the FRA, flexible receiver bag, and the burial container; 2) radiation levels and concentrations of the various radionuclides are needed to assure that the equipment falls within the bounding classifications identified in the Safety Analysis Report for Packaging (Onsite) Long-Length Contaminated Equipment Transport System (HNFSD-TP-SARP-013, Rev. 0); and 3) waste classification is needed to assure that the waste package falls within the solid waste disposal acceptance requirements contained in Hanford Solid Waste Acceptance Criteria Document (WHC-EP-0063-4). 


\section{LONG-LENGTH CONTAMINATED EQUIPMENT DISPOSAL PROCESS PATH}

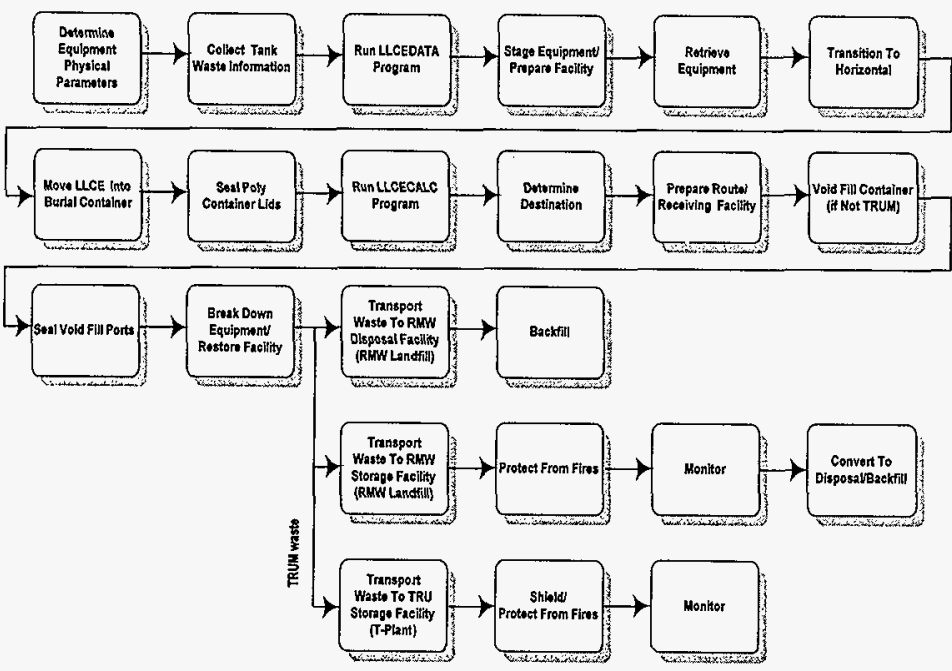

Figure 2. LLCE Equipment Disposal Process Path 


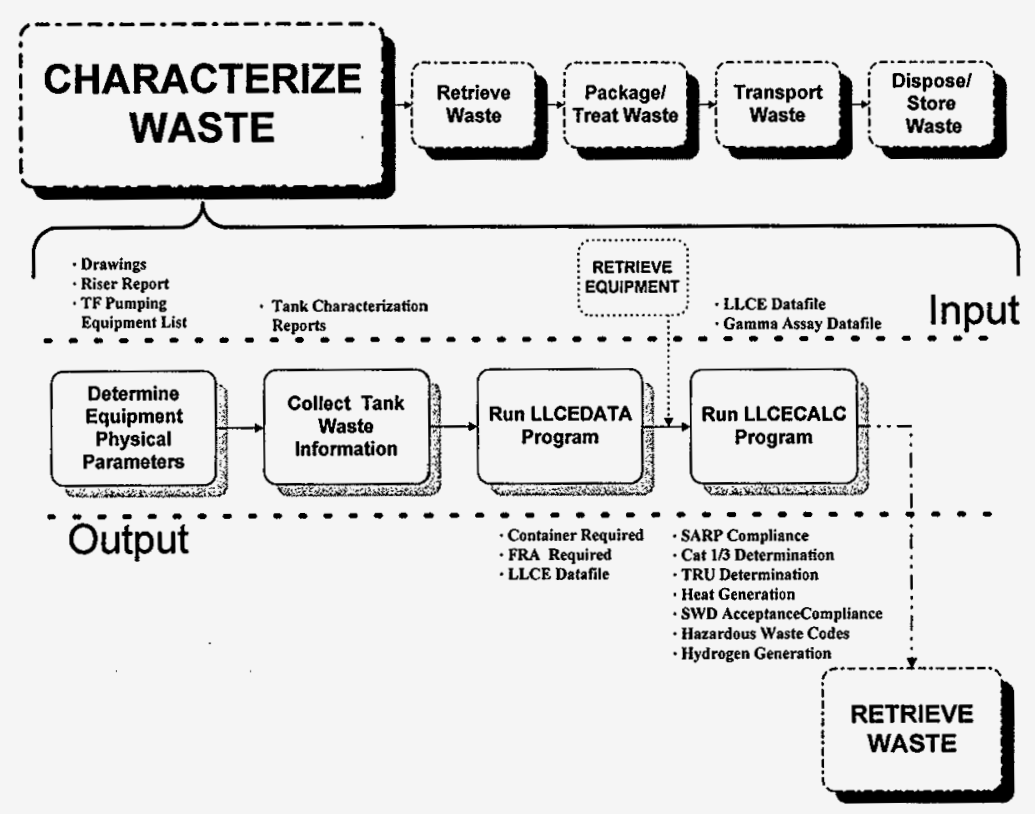

Figure 3. Characterize Waste 
Computer programs LLCEDATA and LLCECALC have been developed to perform the calculations necessary to provide the information and verifications listed above. Appendix $F$ contains the results of a test run of both programs for Tank 104-AW. This test uses gamma assay data gathered during a 101-AZ thermocouple tree retrieval operation. NOTE: The information in this appendix is for illustrative purposes only and it should not be used for an actual retrieval.

\subsubsection{Existing Documentation}

- Disposal of Long-Length Contaminated Equipment: LLCE Characterization Software Functional Criteria and Management Plan, WHC-SD-WM-TCP-007 Rev. 0.

- Disposal of Long-Length Contaminated Equipment: Radiological and Chemical Characterization Plan, WHC-SD-WM-CSWD-080, Rev. 0.

- Waste Certification Summary, 601-01a.

- Tank Farms Pumping Equipment List, WHC-SD-WM-RPT-025.

- $\quad$ Double Shell Underground Waste Storage Tanks Riser Survey, WHC-SD-RE-TI093.

- LLCEDATA and LLCECALC for Windows Version 1.0, Volume I: User's Manual, HNF-3169, Rev. 0.

- LLCEDATA and LLCECALC for Windows Version 1.0, Volume II: Technical Manual, HNF-3169, Rev. 0.

- LLCEDATA and LLCECALC for Windows Version 1.0, Volume III: Software Verification and Validation, HNF-3169, Rev. 0.

\subsubsection{Existing Hardware}

- FRA Gamma Energy Analysis system

\subsubsection{Existing Software}

- LLCE Characterization Database Program (validated and benchmarked).

- LLCE Characterization Program (validated and benchmarked). 
- $\quad$ FRA Gamma Energy Analysis system and computer program.

\subsubsection{User Information Needed to Accomplish Task}

- Prerequisite information needed for the LLCEDATA Program:

- Physical data is required on equipment to be removed (drawing number for equipment is sufficient in most cases since the program contains a pick list and database of 581 types of items that are or have been installed in tanks):

- $\quad$ specific length and weight information, and

- confirmation that equipment was fabricated to drawing number indicated on LLCEDATA to assure that the proper size of container is used; if not, edit and correct the information.

- Tank-specific information required:

- Identify Tank Farm, tank, and riser,

- Number of stratified layers of waste in tank for which characterization information exists (this will be selected automatically if characterization information currently exists in the database or can be overridden if new information is available), and

- Best available characterization information for the tank in question. (This information is best obtained from the Generator Services group of Waste Management Hanford.)

- Geometry Correction Factors required for specific equipment:

- Factors are equipment-specific; they are needed to characterize equipment using gamma assay information acquired during retrieval. Once determined for a particular equipment configuration, the correction factor is good for similar equipment.

- Equipment must be analyzed and factors obtained. The current group performing such work is Criticality and Shielding.

- Prerequisite information needed for the LLCECALC Program:

- Data file produced on LLCEDATA Program prior to retrieval, and

- After LLCE retrieval, assay data files must be downloaded in DOS format from the Microvax computer tied to the FRA gamma assay equipment.

\subsubsection{Issues}

- $\quad$ Some contents of Disposal of Long-Length Contaminate Equipment: LLCE Characterization Software Functional Criteria and Management Plan, WHC-SDWM-TCP-007 Rev. 0, conflict with the LLCE Program information.

- Software has not been reviewed and approved by the TWRS Solid Waste group. 


\subsubsection{Remaining Work}

- $\quad$ Release Rev. 1 of Disposal of Long-Length Contaminated Equipment: LLCE Characterization Software Functional Criteria and Management Plan, WHC-SDWM-TCP-007 Rev. 0. Certain changes were made in the characterization process that are not reflected in this document. (The computer programs, however, are based on these changes.)

- Obtain final concurrence from Waste Management Hanford and the Tank Farms Solid Waste organization on the characterization programs.

- Update the characterization database program (LLCEDATA) with the most current information. This task should be done periodically as new characterization information is compiled.

- Improve the gamma assay software to be more realistic and less conservative. The gamma assay software is currently benchmarked and validated. However, the software is considered overly conservative with respect to transuranic waste. As storage of TRUM is significantly more expensive than storage of mixed waste, significant cost savings may be realized by improving the gamma assay software.

\subsection{Retrieve Waste}

Figure 4 depicts the activities that take place during the "Retrieve Waste" process step. As can be seen, considerable preparation is required prior to actual retrieval activities. Much of the primary retrieval equipment exists (see Section 5.2.2), however, many adapters, spool pieces, and platforms will not be fabricated until they are needed for a particular retrieval effort. Also, consumable items will need to be procured for each retrieval (see Section 5.2.4). 


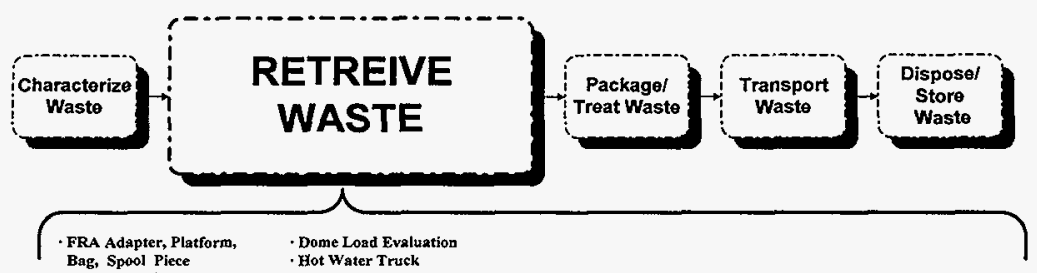

- Hot Water Truck

- Poly Burial Container - Cranc

- Receiver/Transport $\quad$ - Water Pump Trailer $\quad$ - Reciever Trailer $\quad$. Storage Boxes

$\begin{array}{llll}\text { Trailers } & \text { Green house } & \text {. Skad }\end{array}$

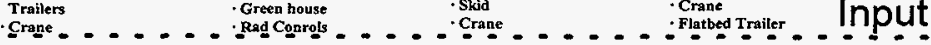

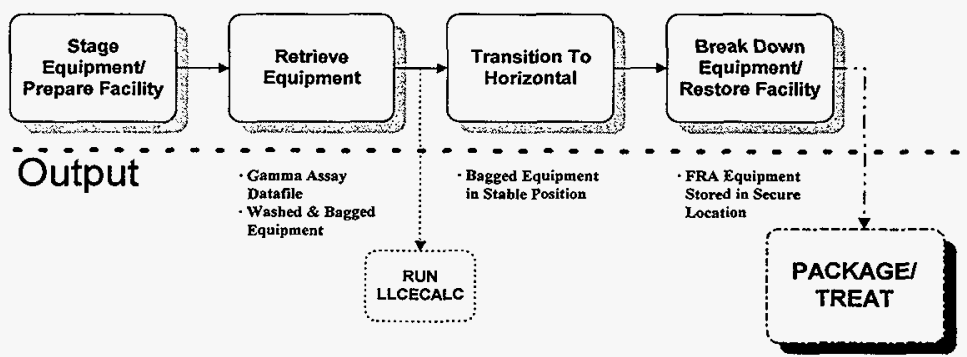

Figure 4. Schematic of the Retrieval Process

\subsubsection{Existing Documentation}

- $\quad$ LLCE Drawing Index, H-2-827806,

- Drawing Index 4-6 Inch Tank 10IAZ Waste Retrieval System, H-2-79335

- $\quad$ Drawing Index 42 Inch Tank 101AZ Waste Retrieval System, H-2-79341

- Drawing H-2-79190 provides arrangement drawings for FRA equipment. It references detailed drawings for individual components, and provides farm/tank/ pit/riser references to the specific elements needed. 
- Work Package No. 2E-95-00858 contains the instructions/procedures that were used to retrieve seven thermocouples from Tank 101-AZ. This information could be beneficial in the development of standardized procedures for operating the FRA equipment. In addition, a Post ALARA Review was performed which may provide further insights (see Section 5.2.5).

- Long-Length Contaminated Equipment (LLCE) Tank Farm Field Verification Report 12/94, WHC-SD-WM-ES-332, Rev 0. This document provides interface and interference details on Tank Farm tanks and DCRT pits.

- $\quad$ Operating Instructions for the 42-Inch Flexible Receiver, HNF-2748, Rev 0.

- Operating Instructions for the 4-Inch and 6-Inch Flexible Receivers, HNF-2749, Rev 0.

- Preparation and General Operating Instructions for LLCE Receiver Trailer, HNF-3071, Rev. 0.

- General Maintenance Instructions for the Flexible Receiver System, HNF-3336, Rev 0.

- General Maintenance Instructions for LLCE Transportation System, HNF-3252, Rev. 0.

\subsubsection{Existing Hardware}

Receiver Trailer HO-64-4283 is located in the lay down yard north of Building 2704-HV.

The existing equipment for the FRA is listed below. This equipment is stored primarily in the lay down yard north of Building 2704-HV and in the Cold Test Facility.

- Basic 4/6-inch and 42-inch FRAs (see H-2-79190).

- Several adapters, platforms, and spool pieces have been fabricated for FRA in conjunction with Projects W-151 and W-320. Others have been designed but will be fabricated on an as needed basis. Until a complete tracking system is developed, it will be necessary to physically check the storage locations for the existence of needed equipment. Part of this task includes determining where the existing Project W-320 adapters and platforms can be used in other Tank Farm locations. 
- Spool piece adapter with capability to pierce equipment for free liquid draining [ultra high pressure (approx 60,000 psi)] currently designed as part of the SY-101 Viscosity Density Temperature Tree (VDTT) removal task.

- Equipment storage boxes have been built to store existing equipment that may be affected by long-term storage in an outdoor environment. In addition, these boxes provide ALARA protection for personnel from low levels of residual contamination that may be present after LLCE retrieval. Additional boxes will be needed as FRA equipment is fabrication.

- Modified Crane HO-17T5691. This Hanford crane has been modified with load cells and other equipment to specifically support this program. Use of a different crane will require similar modifications.

- Water Pump Trailer HO-64-3538 or HO-64-5257.

- Two Control Trailers.

\subsubsection{Existing Software}

- $\quad$ FRA Gamma Energy Analysis system.

\subsubsection{Consumables}

Several items will either be used up or disposed during retrieval operations. These items will be procured for each retrieval. A limited number of spares should be kept onsite, available for high priority emergent activities. Consumables include flexible receiver bags, inner lifting bail, inner water connection hose, burial containers, skids, and strippable ALARA coatings for adapters. In some cases, adapters and/or spool pieces may be disposed of due to residual contamination levels.

\subsubsection{Lessons Learned}

A Post ALARA Review was performed after the retrieval of seven thermocouple trees from Tank 101-AZ (part of the Project W-151 efforts). This review is archived in Work Package No. 2E-95-00858. Several difficulties were encountered during the initial retrieval efforts; this review documents the resolution of these problems and observations of ways to reduce personnel exposure and increase the efficiency of the activities. Several key elements of this review are listed below. 
- A 20 foot exclusion zone around the FRA was established to control access to the equipment and reduce exposure. Controls were set up for time allowed in prespecified radiation fields.

- Remote tools and crane boom movements were used to manipulate the LLCE. This was needed because waste buildup on equipment being retrieved caused them to become lodged in the riser on several occasions.

- A whirling water spray was used to wash down the inside of the FRA immediately after an equipment pull. This, along with the application of a strippable coating applied to the inside of the FRA, enhanced decontamination efforts.

- The secondary bag (installed on the bottom of the bagged equipment) should be located as close to the FRA as possible to reduce the potential for contamination spread.

- $\quad$ A HEPA filtered vacuum was identified as a means of simplifying decontamination of the lower glove bag. This vacuum and a shielded drum prefilter were procured and fabricated to support future retrieval efforts.

- It was suggested that the use of a disposable plastic liner, to be inserted in the FRA and disposed after each retrieval, be explored to further reduce the decontamination efforts.

- "Lollipops" of crystallized/solidified waste on the lower end of the thermocouple trees were sheared off as they entered the risers forming a plug that caused the high pressure wash water to back up in the FRA. No fix has been identified or design change implemented to correct this problem in future retrieval efforts. NOTE: Risers should not be allowed to become plugged. An in-tank ClosedCircuit Television (CCTV) camera should be installed in an adjacent riser to monitor for this condition.

\subsubsection{Issues}

- Vendor information files have not been established. Don Legare has a good collection of vendor cut sheets, drawings, etc., for the FRA. Bill McCormick has a collection of vendor information for the Receiver Trailer. 
- Equipment is currently stored both north of Building 2704-HV and at the Cold Test Facility. There does not appear to be any documentation to indicate which elements have been fabricated and where they are stored.

- "Lollipops" have plugged risers causing water to backup in the FRA and actually jamming the LLCE in the riser. The design and/or operating methods should be modified to preclude this condition. An in-tank CCTV system should always be used during the removal process.

\subsubsection{Remaining Work}

- Establish vendor information files.

- Fabricate platforms, adapters, spool pieces, and storage boxes on an as-needed basis.

- $\quad$ Procure and stage flexible bags for emergency use. Bags for pre-planned use should be purchased on an as-needed basis prior to retrieval activities.

- Develop maintenance and storage procedures. General maintenance instructions for the Flexible Receiver System and the Receiver Trailer are provided in HNF3336 and HNF-3252.

- Perform Receiver Trailer long-term storage and pre-use maintenance. The trailer has been stored in an outdoor environment for an extended time period. There are maintenance items, recommended by the equipment vendors, that should be performed prior to extended periods without operating the equipment. No maintenance has been performed on the trailer. Long-term storage, pre-use, and periodic maintenance items are identified in HNF-3252.

- $\quad$ Prepare TWRS Operating Procedures for the Flexible Receiver System and assay equipment. Procedures are needed also for preparation and staging of the Receiver Trailer. General operating instructions are provided in HNF-2748, HNF-2749, and HNF-3071.

- Make design and equipment modifications to enhance ease of decontamination (Project W-211 may fund a portion of this).

- Improve the LLCE wash system (high pressure to ultra high pressure and/or nozzle arrangement). This is prompted by the difficulty encountered in cleaning 
off equipment during the Tank 101- $\mathrm{AZ}$ retrieval work.

- $\quad$ Perform an Unreviewed Safety Question (USQ) screening and possible safety analysis on retrieval efforts with respect to the flammable gas issues.

- $\quad$ Provide in-tank CCTV system.

\subsection{Package/Treat Waste}

Figure 5 depicts the activities that take place during the "Package/Treat Waste" process step. The packaging and treatment step takes place after equipment is retrieved from the tank and bagged. It begins when the waste item is captured by the receiver trailer tilt assembly and involves transitioning the waste to a horizontal position, pushing the LLCE (contained in a skid assembly) into the burial container, sealing of the container lid, and void fill of the container (macro-encapsulation) once it is confirmed by the LLCECALC Program that the waste is not suspect TRUM and that hydrogen generation will not be excessive. If it is determined that the waste is suspect TRUM, void fill will not take place and the LLCE will be prepared for transport to a storage facility as described in Sections 5.5 and 5.6. 


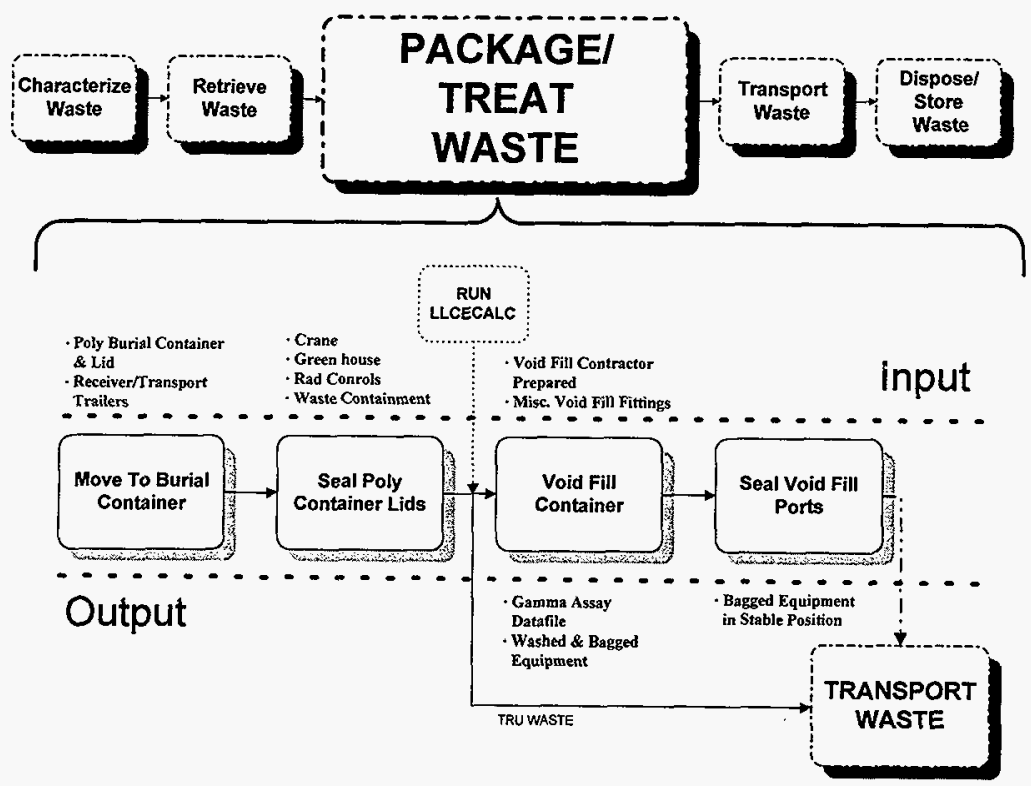

Figure 5. Package/Treat Waste

\subsubsection{Existing Documentation}

- Packaging Design Criteria, Transfer and Disposal of Long-Length Equipment, Hanford Tank Farm Complex, WHC-SD-TP-PDC-020.

- Specification for Trailers for the Handling and Transport of Tank Farms LongLength Contaminated Equipment, WHC-S-0321, Rev. $1 \mathrm{~A}$.

- Specification for Contaminated Equipment Burial Container, WHC-S-0402 Rev. 0. 
- Specification for Void Fill of the Long-Length Contaminated Equipment Burial Container, HNF-0568, Rev. 0.

- Long-Length Contaminated Equipment Burial Containers Fabrication Process Procedures, HNF-SD-WM-SPP-002, Rev. 0.

- General Operating Instructions for LLCE Transportation System, HNF-3069, Rev. 0 .

- Preparation and General Operating Instructions for LLCE Transport Trailer, HNF-3070, Rev. 0.

- Preparation and General Operating Instructions for LLCE Receiver Trailer, HNF-3071, Rev. 0.

- General Maintenance Instructions for LLCE Transportation System, HNF-3252, Rev. 0.

- $\quad$ LLCE Drawing Index, H-2-827806.

\subsubsection{Existing Hardware}

- $\quad$ Receiver Trailer HO-64-4283 and Transport Trailer HO-64-4280 are located in the lay down yard north of Building 2704-HV.

- Burial containers: one, 54-inch diameter container, and three, 26-inch diameter (for SY Farm VDTTs). Containers are complete with skids.

\subsubsection{Issues}

- Vendor information files have not been established for the burial containers or the trailers. Bill McCormick has vendor information for the trailers.

- The SARP hydrogen gas generation analysis indicates that with the worst case waste, the Lower Flammable Limit is reached in approximately six hours. A gas generation evaluation should be performed during the "characterization" phase to assure that a safe situation is maintained (this evaluation can be added to the LLCE Characterization Database Program). 


\subsubsection{Remaining Work}

- Develop maintenance and storage procedures. General maintenance instructions for the Receiver and Transport Trailers are provided in HNF-3252.

- $\quad$ Perform Receiver and Transport Trailer long-term storage and pre-use maintenance. The trailers have been stored in an outdoor environment for an extended time period. There are maintenance items, recommended by the equipment vendors, that should be performed prior to extended periods without operating the equipment. No maintenance activities have been performed on the trailers. Long-term storage, pre-use, and periodic maintenance items are identified in HNF-3252.

- $\quad$ Prepare TWRS Operating Procedures for trailer staging, equipment capture (on tilt trailer in vertical position), lay down, trailer positioning, and transfer to the disposal container, container sealing, void fill operations, and container handling and storage (both empty and filled). General operating instructions for the trailers are provided in HNF-3069, HNF-3070, and HNF-3071.

- Provide specialized training for the sealing process. Due to the critical nature of this process, work should be performed by technicians.

- Assure that adequate Notice of Construction (NOC) permitting is in place for the void fill operation (may be able to use Project W-151 documentation).

\subsection{Transport Waste}

Figure 6 depicts the activities that will take place in the "Transport Waste" process step.

Transportation of the containerized LLCE should not take place until the LLCECALC computer program has verified that the waste falls within the constraints identified in the SARP and the Hanford Solid Waste Acceptance Criteria document, WHC-EP-0063-4, since this determination controls the destination of the LLCE.

The LLCE transport trailer has been designed to carry the heavy (void filled) equipment from the tank farms to the storage or final disposal location. Steerable rear axles on the trailer make it possible to negotiate corners en route to the LLCE destination without establishing new roads or making major modifications to existing roads. Still, prior to equipment transport, the route must be checked for interferences such as stop signs, utility poles, overhead wires, etc. Controls will 


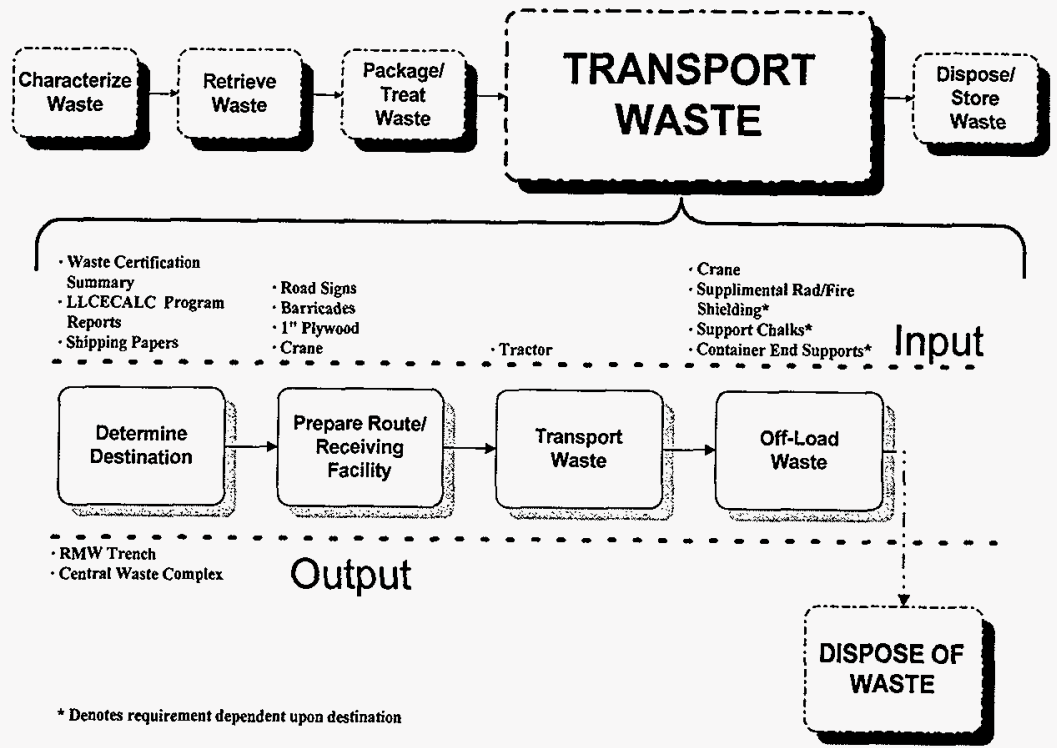

Figure 6. Transport Waste

be placed on the transport by the SARP and possibly the work package. Examples of the controls include:

- Establishment and dry run of the transport route.

- Use of an escort vehicle.

- Closing of certain "higher risk" sections of the transport route. 
- Establishment of a "rolling zone" around the transport trailer for ALARA concerns.

- Weather limitation controls associated with wind, temperature, and slick roads.

- Maximum transport speed limitations (i.e., $15 \mathrm{mph}$ on straight stretches).

In most cases, LLCE will be driven straight to the mixed-waste landfill. The ramp leading into the landfill is made of compacted backfill. Due to the high weight of the transport trailer and void filled container, it may be necessary to condition the ramp surface prior to the first entrance. In addition, the bottom of the landfill where the truck will drive should be lined with one-inch plywood (or other suitable material) to distribute the load.

\subsubsection{Existing Documentation}

- Specification for Trailers for the Handling and Transport of Tank Farms LongLength Contaminated Equipment, WHC-S-0321 Rev. 1 A.

- Safety Analysis Report for Packaging (On Site) Long-Length Contaminated Equipment Transport System, HNF-SD-TF-SARP-013, Rev, 0.

- General Operating Instructions for LLCE Transportation System, HNF-3069, Rev. 0 .

- Preparation and General Operating Instructions for LLCE Transport Trailer, HNF-3070, Rev. 0.

\subsubsection{Existing Hardware}

- Transport Trailer HO-64-4280 is located in the lay down yard north of Building 2704-HV.

- Tractors for pulling trailers are standard units available onsite.

- $\quad$ Receiver Trailer: Ford LTS 9000.

- Transport Trailer: Mack DM897SX.

\subsubsection{Issues}

- Current trench design may not support positioning trailer for off-loading.

- $\quad$ Grade may be too steep with current gravel base, causing truck tires to spin 
going up the ramp.

- Bottom of grade may need a corner widened to support turning radius of the trailer.

\subsubsection{Remaining Work}

- $\quad$ Prepare TWRS Operating Procedures for transport trailer (include loading and securing of containers, handling containers that come out remote-handled, roadway constraints, mixed-waste trench/storage facility interfaces, and offloading). General operating instructions for the transport trailer are provided in HNF-3069 and HNF-3070.

- Perform a dry run of the trailer entering the mixed-waste trench. This dry nun should be performed with a weighted trailer for the purpose of identifying any necessary modifications and/or conditioning of the trench entrance ramps.

- Modify and/or condition landfill entrance ramps if necessary.

\subsection{Dispose/Store Waste}

Figure 7 depicts the activities that will take place in the "Dispose/Store Waste" process step. Depending on the characterization determination of LLCE by the LLCECALC Program after retrieval, two primary alternatives currently exist as a destination. Waste Management Hanford is still in the process of finalizing what approach will be taken and establishing appropriate permitting requirements. The following descriptions are therefore subject to change based on the results of these efforts. 


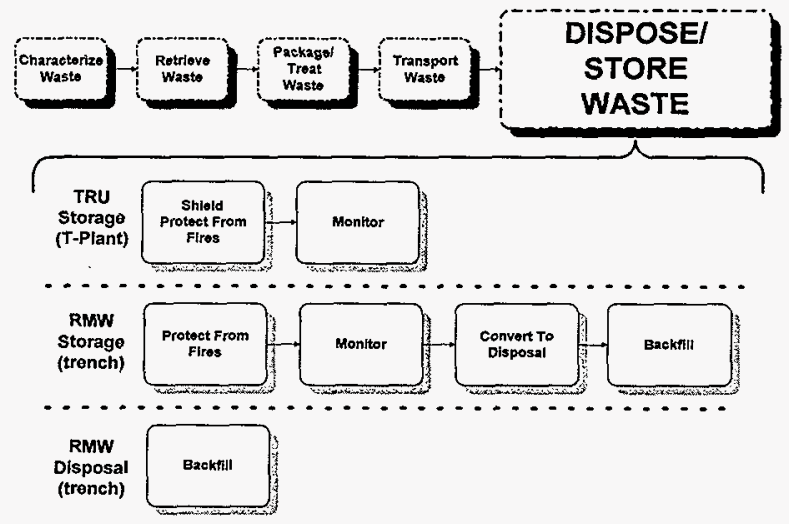

Figure 7. Dispose/Store Waste

1) RMW Trench

Two RCRA compliant RMW trenches were constructed under Project W-025, "Radioactive Mixed-Waste Landfill," in the 200 West Area. The trenches have not yet been put into service for disposal due to the difference in cost associated with operation compared with the limited quantity of RMW that is staged for disposal at this point. Current funding plans are for the trench(es) to be opened for disposal in Fiscal Year (FY) 2000. In the meantime, the trenches have been permitted to allow storage of such items as LLCE. Equipment will not be buried until the trench is opened for disposal. The storage approach will require regular inspection of burial containers for damage or leakage. Accordingly, chocks will be needed to hold the LLCE off the ground for visual access to the bottom of the containers. Personnel shielding may be required depending on the radiation levels at the surface of the container.

Once the trench is transitioned to a disposal mode, containers will simply be off-loaded, concrete support blocks placed on each end, and the LLCE covered with backfill. 
Only LLCE that has been confirmed to not exceed the threshold for TRUM and hydrogen generation will be stored or disposed in the RMW trenches.

2) Central Waste Complex

LLCE that is characterized as suspect TRUM or has a hydrogen generation rate greater than limits established in the SARP will be stored at T-Plant until a final method of disposal is determined. This storage location will require chocks to facilitate inspection and may require an overpack container or some other form of barrier to provide shielding and fire protection for the poly containers.

\subsubsection{Existing Documentation}

- Treatment Options for Long-Length Contaminated Equipment, WHC-SD-WMES-324.

- Hanford Solid Waste Acceptance Criteria, WHC-EP-0063, Rev. 5.

- Chemical Compatibility Study of Cooley L18KU, Herculite, and Elephant Mat With Hanford Tank Waste, HNF-2893, Rev. 0.

- $\quad$ TRU Storage Options Letter Report

\subsubsection{Existing Hardware/Facilities}

- $\quad$ RMW Landfill, Trenches No. 31 and 34

- $\quad$ CWC.

\subsubsection{Issues}

- Current trench design may not support positioning trailer for off-loading.

- The grade may be too steep with current gravel base, causing truck tires to spin going up the ramp.

- The bottom of grade may need a corner to be widened to support turning radius of trailer. 


\subsubsection{Remaining Work}

- Modify and/or condition the landfill entrance ramps if necessary. A dry run with a weighted transport trailer should be performed to identify any required changes to the ramps.

- $\quad$ Storage in Mixed-Waste Trench:

- Develop Solid Waste Disposal Procedures for locating equipment in and monitoring LLCE in the mixed-waste trenches in the storage mode.

- Design and fabrication of support chocks to support containers off the ground for inspection during storage must be completed. It may be possible to use the support chocks used for shipping the burial containers.

- Disposal in Mixed-Waste Trench:

- Design and fabricate "bookends" to place in trench at ends of containers. These devices will carry excessive loads generated by backfill weight on top of containers.

- Solid Waste Disposal must establish a pricing structure for storage and/or disposal of LLCE. 


\begin{tabular}{lr}
\hline LoNG-LeNGTH CONTAMINATED EQUIPMENT DiSPOSAL PROCESS & HNF-SD-WM-ER-730, Rev. 1 \\
Path DoCUMENT - Report No. 987201-001, Rev. 1 & September 1998 \\
\hline \hline
\end{tabular}

Appendix A

Original WesTIP ${ }^{\circledR}$ Process Map 


\section{DISPOSAL OF LONG-LENGTH CONTAMINATED EQUIPMENT CURRENT PROCESS}

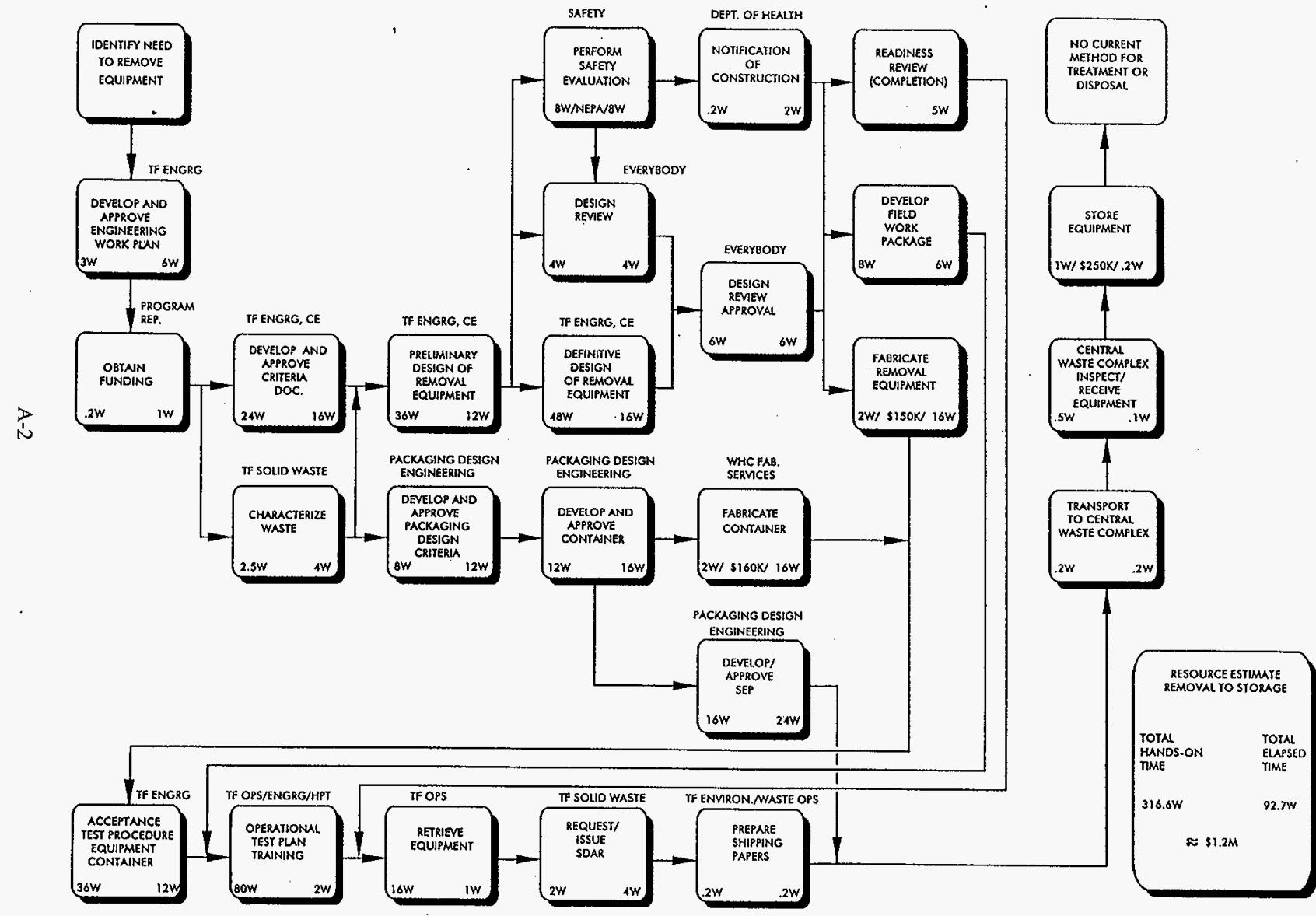


Appendix B

Final WesTIP® Process Map 


\section{DISPOSAL OF LONG-LENGTH CONTAMINATED EQUIPMENT PROCESS}

\begin{tabular}{|c|c|c|c|c|c|c|}
\hline TWRS & TWRS & $\begin{array}{l}\text { Waste Technology } \\
\text { Systems Engineering }\end{array}$ & TWRS & Planner & Plannar/Cog & TWRS \\
\hline $\begin{array}{l}\text { Identify Need } \\
\text { To Remove } \\
\text { LLCE }\end{array}$ & $\begin{array}{l}\text { Initiate } \\
\text { Work } \\
\text { Package }\end{array}$ & $\begin{array}{c}\text { Identify } \\
\text { Physical, Rad., \& } \\
\text { Chemical } \\
\text { Characteristics }\end{array}$ & $\begin{array}{c}\text { Select } \\
\text { Disposal } \\
\text { Mode and } \\
\text { Equipment }\end{array}$ & $\begin{array}{l}\text { Assemble } \\
\text { Work } \\
\text { Package }\end{array}$ & $\begin{array}{l}\text { Review and } \\
\text { Approve } \\
\text { Work } \\
\text { Package }\end{array}$ & $\begin{array}{l}\text { Develop } \\
\text { Schedule }\end{array}$ \\
\hline
\end{tabular}
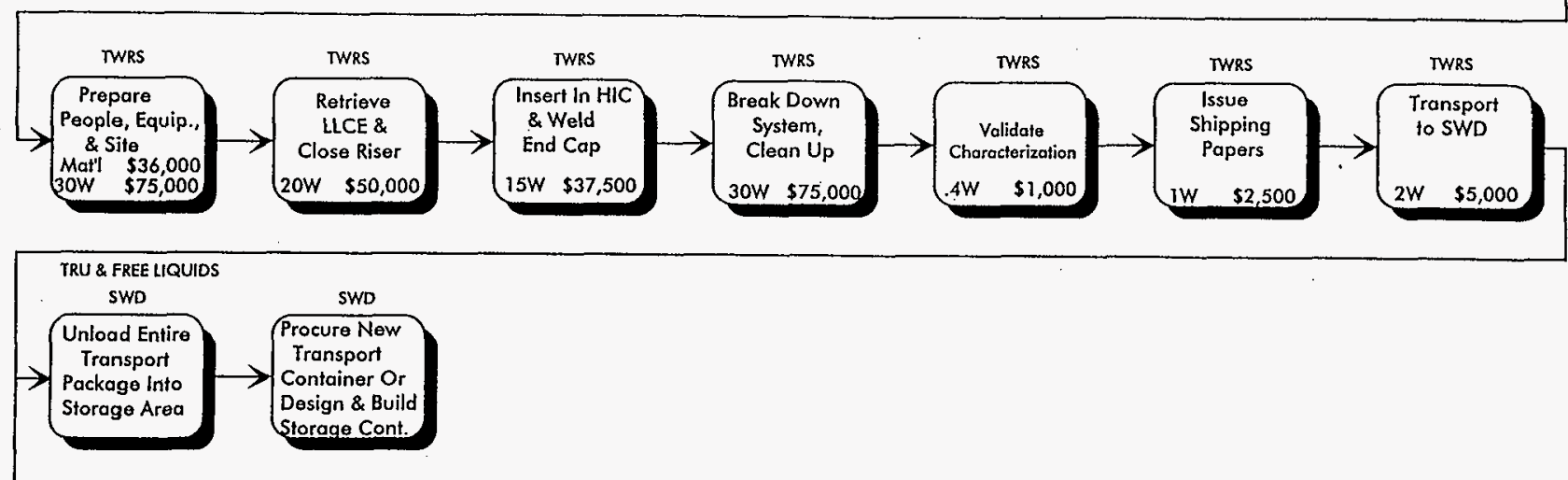

NORMAL RMW

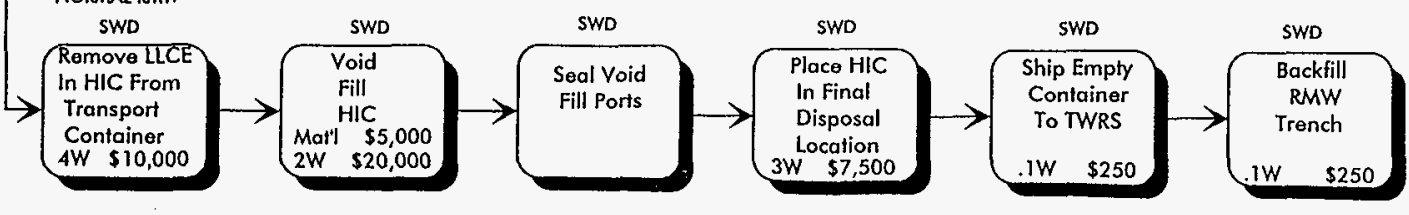




\section{Appendix C}

Drawing Traceability Example 


\section{TANK 104-AW TRANSFER PUMP \\ REMOVAL TEST RUN}

\section{TOP LEVEL DRAWING INDEX}

- H-2-79190 - LLCE EQUIPMENT DRAWING ARRANGEMENTS

- Indicates Arrangement 3

- $\quad$ Provides drawing references to FRA equipment

- $\quad$ Provides information on crane needed, and water pump trailer

- Does not include Burial Containers and Retrieval and Transport Trailers

\section{CONTROL TRAILER}

- H-2-79204 - INDEX (not referenced on H-2-79190)

- H-2-78935 - Assembly Drawing (referenced on H-2-79190)

- $\quad$ This is the preferred of the two existing control trailers; however either will work

- $\quad$ Procedures exist, Don will provide the number

\section{FLEXIBLE RECEIVER TOP ARRANGEMENT}

\section{- H-2-79138 - 42 INCH FLEXIBLE RECEIVER TOP ARRANGEMENT}

\section{ADAPTER/PLATFORM}

- H-2-842755 - 104-AW TANK 4A PIT/RISER \#3A

- Contains pit/riser drawing and, FRA installation drawing

- $\quad$ References adapter [H-2-824818], platform [H-2-824709], and restraint drawings [H-2-824702]

- $\quad$ No instructions provided for installation

\section{FLEXIBLE RECEIVER BAG}

- H-2-79143 - LLCE FLEXIBLE RECEIVER ASSEMBLIES (Referenced on H-2-79190)

- $\quad$ References H-2-79147 LLCE FLEXIBLE RECEIVER FOR 42-INCH RISER, which contains fabrication details for the bag

- H-2-79362 or H-2-79297 TWRS FLEXIBLE RECEIVER LEAK CONTAINMENT BAG/STAND ASSY (Referenced on H-2-79190)

- Drawings appear to be similar, it is not clear if one is more appropriate than the other

- H-2-79125 - LLCE FLEXIBLE RECEIVER CONTAINER LENGTH CALCULATION, (Not referenced on H-2-79190) 


\section{WASH EOUIPMENT}

- H-2-79129 - LLCE INNER WATER CONNECTION TOOL ASSY, (referenced on H-279190) used for internal flushing of waste equipment

- H-2-79142 - LLCE FLEXIBLE RECEIVER INNER WATER HOSE ASSEMBLIES, (referenced on H-2-79190) provides connections for flush water inside the receiver bag

- H-2-7913I - PRIMER PUMP AND HOSE DETAILS, (referenced on H-2-79190), provides details for pump needed between water truck and pumping trailer

\section{LIFTING BAIL}

- H-2-79181 - LLCE BAIL ASSEMBLY II, (referenced on H-2-79190) provides details for bail assembly to be used inside the flexible receiver bag

\section{BURIAL CONTAINER}

- LLCEDATA - Computer program indicates which container to use (C-5)

- H-2-827806 - LLCE DRAWING NDEX, (not referenced on H-2-79190) provides references to container and miscellaneous related equipment drawings, does not indicate which container to use in a given application 


\section{Appendix D}

\section{LLCE Program Summary of Remaining Work}




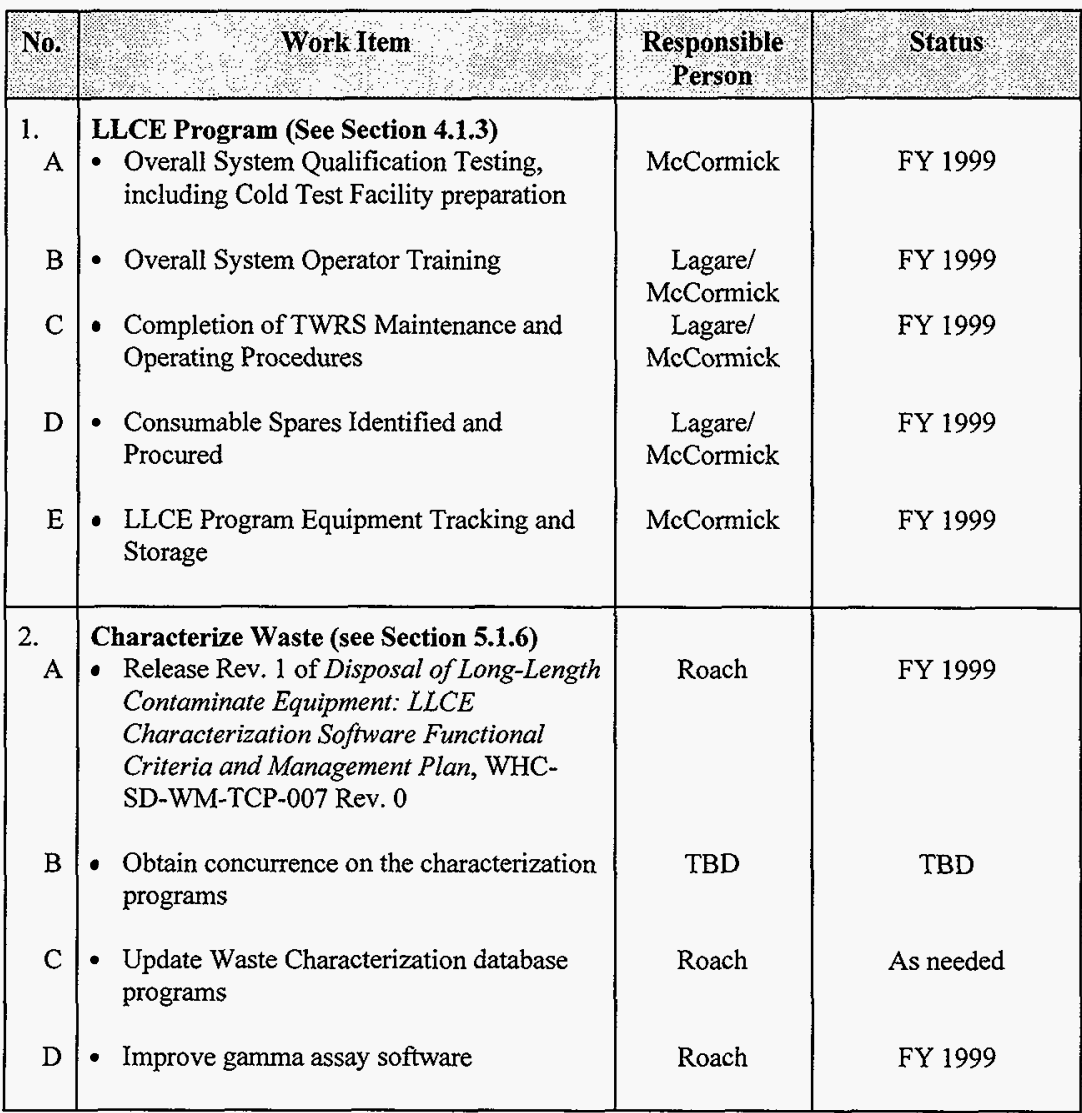




\begin{tabular}{|c|c|c|c|}
\hline No. & (4) Work Item & $\begin{array}{l}\text { Responsible } \\
\text { Person }\end{array}$ & Status \\
\hline 3. & $\begin{array}{l}\text { Retrieve Waste (see Section 5.2.7) } \\
\text { - Establish vendor information files }\end{array}$ & Lagare & FY 1999 \\
\hline B & $\begin{array}{l}\text { - Fabricate platforms, adapters, spool pieces, } \\
\text { and storage boxes on an as-needed basis }\end{array}$ & Lagare & As needed \\
\hline $\mathrm{C}$ & $\begin{array}{l}\text { - Procure and stage flexible bags for } \\
\text { emergency use }\end{array}$ & Lagare & FY 1999 \\
\hline $\mathrm{D}$ & $\begin{array}{l}\text { - Develop TWRS Maintenance and Storage } \\
\text { Procedures }\end{array}$ & Lagare & FY 1999 \\
\hline$E$ & $\begin{array}{l}\text { - Perform long term storage maintenance on } \\
\text { trailers }\end{array}$ & TBD & As needed \\
\hline $\mathrm{F}$ & $\begin{array}{l}\text { Develop TWRS Operating Procedures for } \\
\text { the FRA and receiver trailer (preparation } \\
\text { and staging) }\end{array}$ & Lagare & FY 1999 \\
\hline $\mathrm{G}$ & $\begin{array}{l}\text { - Develop TWRS procedures for assay } \\
\text { equipment }\end{array}$ & Lagare/Roach & FY 1999 \\
\hline $\mathrm{H}$ & $\begin{array}{l}\text { - Make design and equipment modifications } \\
\text { to enhance decontamination }\end{array}$ & Lagare & $\begin{array}{l}\text { Project W-211 } \\
\text { or FY } 1999\end{array}$ \\
\hline I & - Improve the LLCE wash system & Lagare & $\begin{array}{l}\text { Project W-211 } \\
\text { or FY } 1999\end{array}$ \\
\hline $\mathbf{J}$ & - Provide in-tank CCTV system & McCormick & FY 1999 \\
\hline
\end{tabular}




\begin{tabular}{|r|r|r|r|}
\hline \hline LONG-LENGTH CONTAMINATED EQUIPMENT DISPOSAL PROCESS & HNF-SD-WM-ER-730, Rev \\
PATH DOCUMENT - Report No. 987201-001, Rev. 1
\end{tabular}




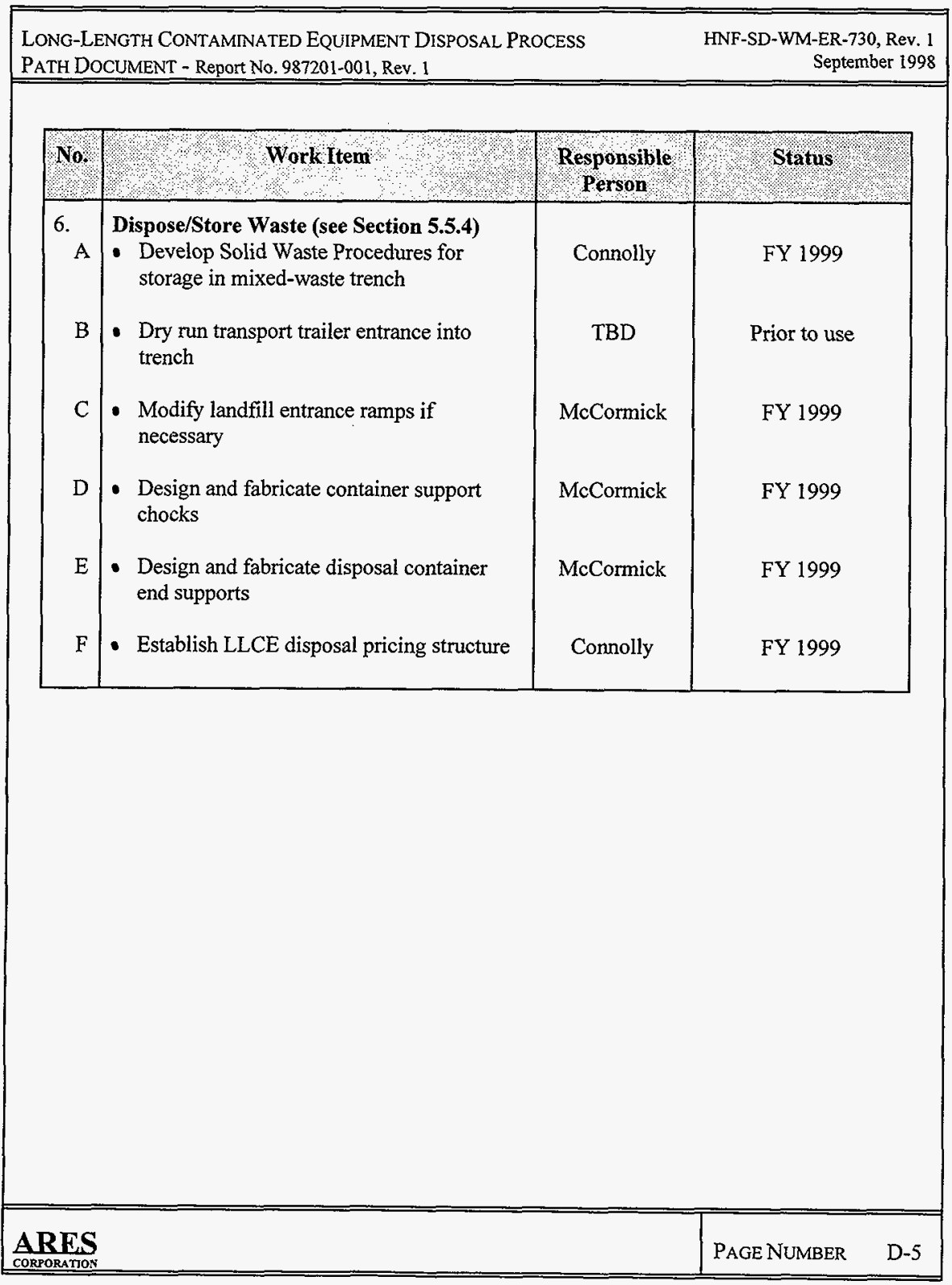




\section{Appendix E}

Procedure Matrix 


\begin{tabular}{|c|c|c|c|c|c|}
\hline \multicolumn{6}{|c|}{$\begin{array}{l}\text { LONG-LENGTH CONTAMINATED EQUIPMENT DISPOSAL SYSTEM } \\
\text { TWRS PROCEDURE MATRIX }\end{array}$} \\
\hline \multirow[t]{2}{*}{ TASK } & \multicolumn{2}{|c|}{ VENDOR SUPPILED } & \multirow{2}{*}{\multicolumn{3}{|c|}{ 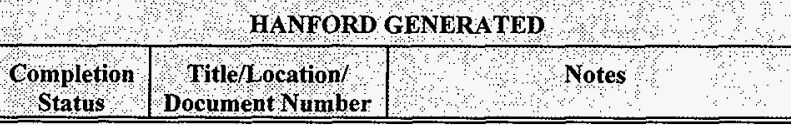 }} \\
\hline & $\begin{array}{c}\text { Completion } \\
\text { Status }\end{array}$ & $\begin{array}{l}\text { Vendor Information } \\
\text { File Number }\end{array}$ & & & \\
\hline \multicolumn{6}{|l|}{ SYSTEM } \\
\hline $\begin{array}{l}\text { Overall System } \\
\text { Qualification Test } \\
\text { Procedure }\end{array}$ & $\mathrm{N} / \mathrm{A}$ & $\mathrm{N} / \mathrm{A}$ & No & & Not Started \\
\hline $\begin{array}{l}\text { LLCE Training } \\
\text { Procedure }\end{array}$ & $\mathrm{N} / \mathrm{A}$ & $\mathrm{N} / \mathrm{A}$ & No & & $\begin{array}{l}\text { Not Started. Some training materials } \\
\text { generated for project } W-151 \text { may be } \\
\text { applicable }\end{array}$ \\
\hline \multicolumn{6}{|l|}{ CHARACTERIZE } \\
\hline $\begin{array}{l}\text { LLCEDATA Computer } \\
\text { Program }\end{array}$ & $\mathrm{N} / \mathrm{A}$ & N/A & Yes & & \\
\hline $\begin{array}{l}\text { LLCECALC Computer } \\
\text { Program }\end{array}$ & N/A & $\mathrm{N} / \mathrm{A}$ & Yes & & \\
\hline $\begin{array}{l}\text { FRA Gamma Assay } \\
\text { Equipment Operating } \\
\text { Procedures }\end{array}$ & N/A & & No & & LLCE Procedures not written \\
\hline
\end{tabular}




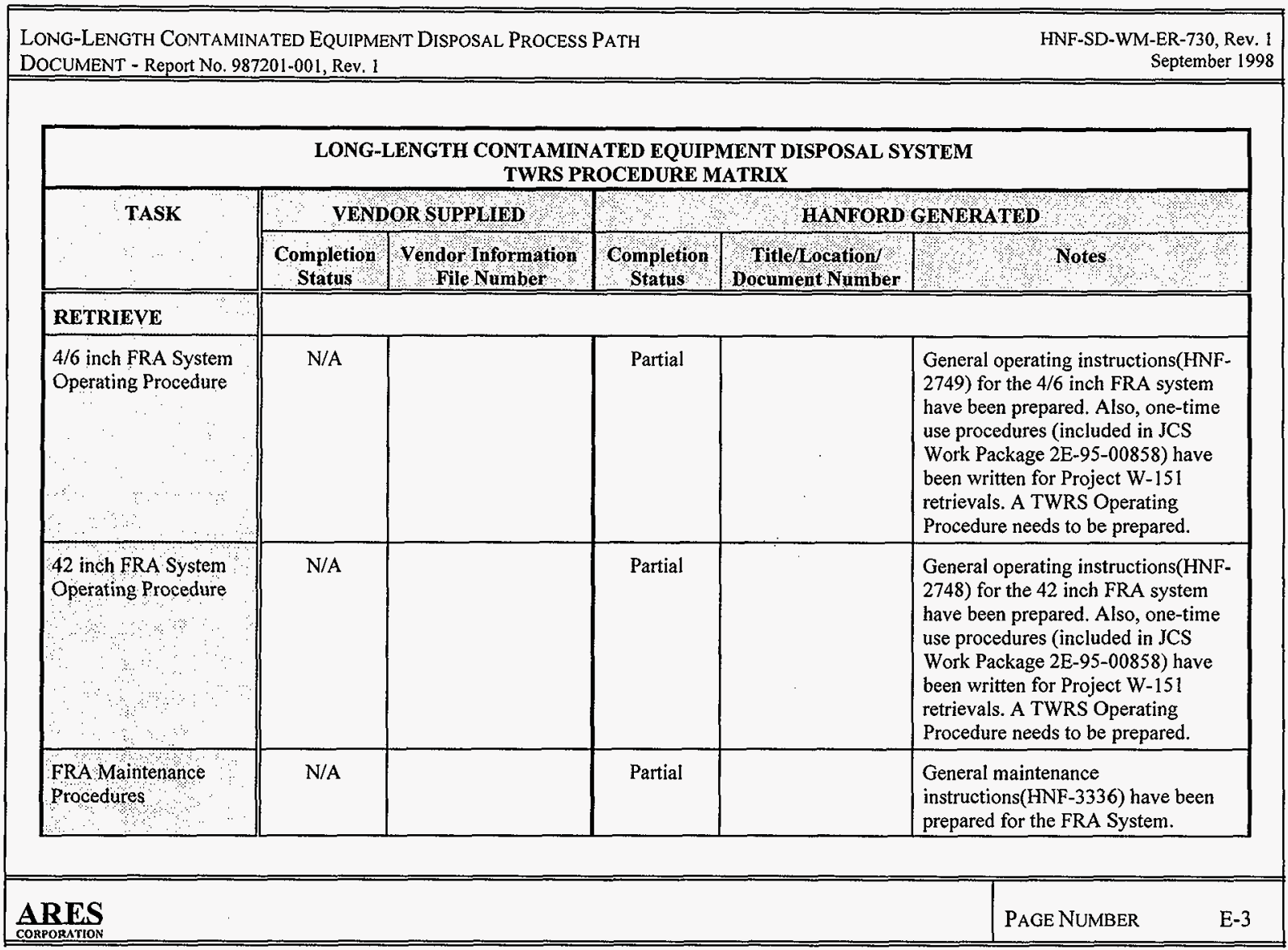




\begin{tabular}{|c|c|c|c|c|c|}
\hline \multicolumn{6}{|c|}{$\begin{array}{l}\text { LONG-LENGTH CONTAMINATED EQUIPMENT DISPOSAL SYSTEM } \\
\text { TWRS PROCEDURE MATRIX }\end{array}$} \\
\hline \multirow[t]{2}{*}{ TASKK } & \multicolumn{2}{|c|}{ VENDOR SUPPLIED } & \multicolumn{3}{|c|}{ HANFORD GENERATED } \\
\hline & $\begin{array}{l}\text { Completion } \\
\text { Status }\end{array}$ & $\begin{array}{l}\text { Yendor Information } \\
\text { File Number }\end{array}$ & Completion & $\begin{array}{l}\text { Titlel Location/: } \\
\text { Document Number }\end{array}$ & ४. \\
\hline $\begin{array}{l}\text { FRA Gamma Assay } \\
\text { Equipment Operating } \\
\text { Procedures }\end{array}$ & N/A & & No & & \\
\hline $\begin{array}{l}\text { Site Setup/Tear-down } \\
\text { Procedure }\end{array}$ & N/A & & Partial & & $\begin{array}{l}\text { Some information may be available } \\
\text { from Project W-151. General } \\
\text { operating instructions (HNF-3070 } \\
\text { and HNF-3071) have been prepared } \\
\text { which provide trailer setup and } \\
\text { preparation information. }\end{array}$ \\
\hline
\end{tabular}




\begin{tabular}{|c|c|c|c|c|c|}
\hline \multicolumn{6}{|c|}{$\begin{array}{l}\text { LONG-LENGTH CONTAMINATED EQUIPMENT DISPOSAL PROCESS PATH } \\
\text { DOCUMENT - Report No. } 987201 \text {-001, Rev. } 1\end{array}$} \\
\hline \multicolumn{6}{|c|}{$\begin{array}{l}\text { LONG-LENGTH CONTAMINATED EQUIPMENT DISPOSAL SYSTEM } \\
\text { TWRS PROCEDURE MATRIX }\end{array}$} \\
\hline TASK & VENI & OR SUPPLIED & 4 & HANFORD & GENERATED \\
\hline$\therefore \quad$ & $\begin{array}{c}\text { Completion } \\
\text { Status } \\
\end{array}$ & $\begin{array}{l}\text { Vendor Information } \\
\text { File Number }\end{array}$ & Completion & $\begin{array}{l}\text { Title/Location/s } \\
\text { Document Number }\end{array}$ & Notes \\
\hline \multicolumn{6}{|l|}{ PACKAGE/TREAT } \\
\hline $\begin{array}{l}\text { Receiver Trailer } \\
\text { Operating Procedures } \\
\end{array}$ & Partial & & Partial & & $\begin{array}{l}\text { General operating instructions(HNF- } \\
3069 \text { \& HNF-3071) have been } \\
\text { prepared for the Receiver Trailer. A } \\
\text { TWRS Operating Procedure needs to } \\
\text { be prepared. }\end{array}$ \\
\hline $\begin{array}{l}\text { Receiver Trailer } \\
\text { Maintenance and } \\
\text { Storage Procedure }\end{array}$ & Partial & & Partial & & $\begin{array}{l}\text { General maintenance } \\
\text { instructions(HNF-3252) have been } \\
\text { prepared for the LLCE } \\
\text { Transportation System, including } \\
\text { Receiver Trailer. }\end{array}$ \\
\hline $\begin{array}{l}\text { Burial Container } \\
\text { Operating Procedure } \\
\text { (storage, handling, } \\
\text { loading, sealing) }\end{array}$ & Partial & & Yes & & \\
\hline $\begin{array}{l}\text { Burial Container Void } \\
\text { Fill Procedure }\end{array}$ & TBD & & Yes & & \\
\hline
\end{tabular}




\begin{tabular}{|c|c|c|c|c|c|}
\hline \multicolumn{5}{|c|}{$\begin{array}{l}\text { LONG-LENGTH CONTAMINATED EQUIPMENT DISPOSAL PROCESS PATH } \\
\text { DOCUMENT - Report No. } 987201-001 \text {, Rev. } 1\end{array}$} & $\begin{array}{r}\text { HNF-SD-WM-ER-730, Rev, } 1 \\
\text { September } 1998\end{array}$ \\
\hline \multicolumn{6}{|c|}{$\begin{array}{l}\text { LONG-LENGTH CONTAMINATED EQUIPMENT DISPOSAL SYSTEM } \\
\text { TWRS PROCEDURE MATRIX }\end{array}$} \\
\hline TASK & \multicolumn{2}{|c|}{ VENDOR SUPPEIED } & \multicolumn{3}{|c|}{ HANFORD GENER ATED } \\
\hline$\left[\begin{array}{c}0 \\
\end{array}\right.$ & $\begin{array}{l}\text { Completion } \\
\text { Status } \\
\end{array}$ & $\begin{array}{l}\text { Vendor loformation } \\
\text { File Number }\end{array}$ & $\begin{array}{l}\text { Completion } \\
\text { Status }\end{array}$ & $\begin{array}{l}\text { Title/Location, } \\
\text { Document Number }\end{array}$ & Notes, \\
\hline \multicolumn{6}{|l|}{ TRANSPORT } \\
\hline $\begin{array}{l}\text { Transport Trailer } \\
\text { Operating Procedures } \\
\end{array}$ & Partial & & Partial & & $\begin{array}{l}\text { General operating instructions(HNF- } \\
3069 \text { \& HNF-3070) have been } \\
\text { prepared for the Transport Trailer. A } \\
\text { TWRS Operating Procedure needs to } \\
\text { be prepared. }\end{array}$ \\
\hline $\begin{array}{l}\text { Transport Trailer } \\
\text { Maintenance and } \\
\text { Storage Procedure }\end{array}$ & Partial & & Partial & & $\begin{array}{l}\text { General maintenance } \\
\text { instructions(HNF-3252) have been } \\
\text { prepared for the LLCE } \\
\text { Transportation System, including } \\
\text { Transport Trailer. }\end{array}$ \\
\hline \multicolumn{6}{|l|}{ DISPOSE/STORE } \\
\hline TRUM Waste Storage & N/A & & No & & $\begin{array}{l}\text { This procedure should be written by } \\
\text { Sold Waste Disposal by the CWC if } \\
\text { and when equipment is removed that } \\
\text { is suspect TRUM }\end{array}$ \\
\hline$\underset{\text { CORPORATION }}{\text { ARES }}$ & & & & & PAGE NUMBER \\
\hline
\end{tabular}




\begin{tabular}{|c|c|c|c|c|c|}
\hline \multicolumn{5}{|c|}{$\begin{array}{l}\text { LONG-LENGTH CONTAMINATED EQUIPMENT DISPOSAL PROCESS PATH } \\
\text { DOCUMENT - Report No. } 987201-001 \text {, Rev. } 1\end{array}$} & $\begin{array}{r}\text { HNF-SD-WM-ER-730, Rev. } 1 \\
\text { September } 1998\end{array}$ \\
\hline \multicolumn{6}{|c|}{$\begin{array}{l}\text { LONG-LENGTH CONTAMINATED EQUIPMENT DISPOSAL SYSTEM } \\
\text { TWRS PROCEDURE MATRIX }\end{array}$} \\
\hline \multirow[t]{2}{*}{ TASK } & \multicolumn{2}{|c|}{ VENDOR SUPPLIED } & \multicolumn{3}{|c|}{ HANFORD GENERATED } \\
\hline & $\begin{array}{c}\text { Completion } \\
\text { Status } \\
\end{array}$ & $\begin{array}{l}\text { Vendor Iriformation } \\
\text { File Number }\end{array}$ & $\begin{array}{l}\text { Completion } \\
\text { Status }\end{array}$ & $\begin{array}{l}\text { Title/Location } \\
\text { Document Number }\end{array}$ & अ \\
\hline $\begin{array}{l}\text { RMW Waste Storage } \\
\text { Procedure (mixed- } \\
\text { waste trench) }\end{array}$ & N/A & & No & & $\begin{array}{l}\text { This procedure should be written by } \\
\text { Solid Waste Disposal to facilitate } \\
\text { storage of LLCE in the trench until } \\
\text { the trench is designated for disposal. }\end{array}$ \\
\hline $\begin{array}{l}\text { RMW Waste Disposal } \\
\text { Procedure (mixed- } \\
\text { waste trench) }\end{array}$ & N/A & & No & & $\begin{array}{l}\text { This procedure should be written by } \\
\text { Solid Waste Disposal to govern } \\
\text { container off-loading, and burial } \\
\text { operations. }\end{array}$ \\
\hline
\end{tabular}


LONG-LENGTH CONTAMINATED EQUIPMENT DISPOSAL PROCESS

HNF-SD-WM-ER-730, Rev. 1

PATH DOCUMENT - Report No. 987201-001, Rev. 1 September 1998

Appendix F

Characterization Computer Program Example 


\section{LLCEDATA PROGRAM TEST RUN}

Note: Test run was performed for tank 241-AW-104 
I AIYK CHAKACI EKILA I IUN UAIABASE

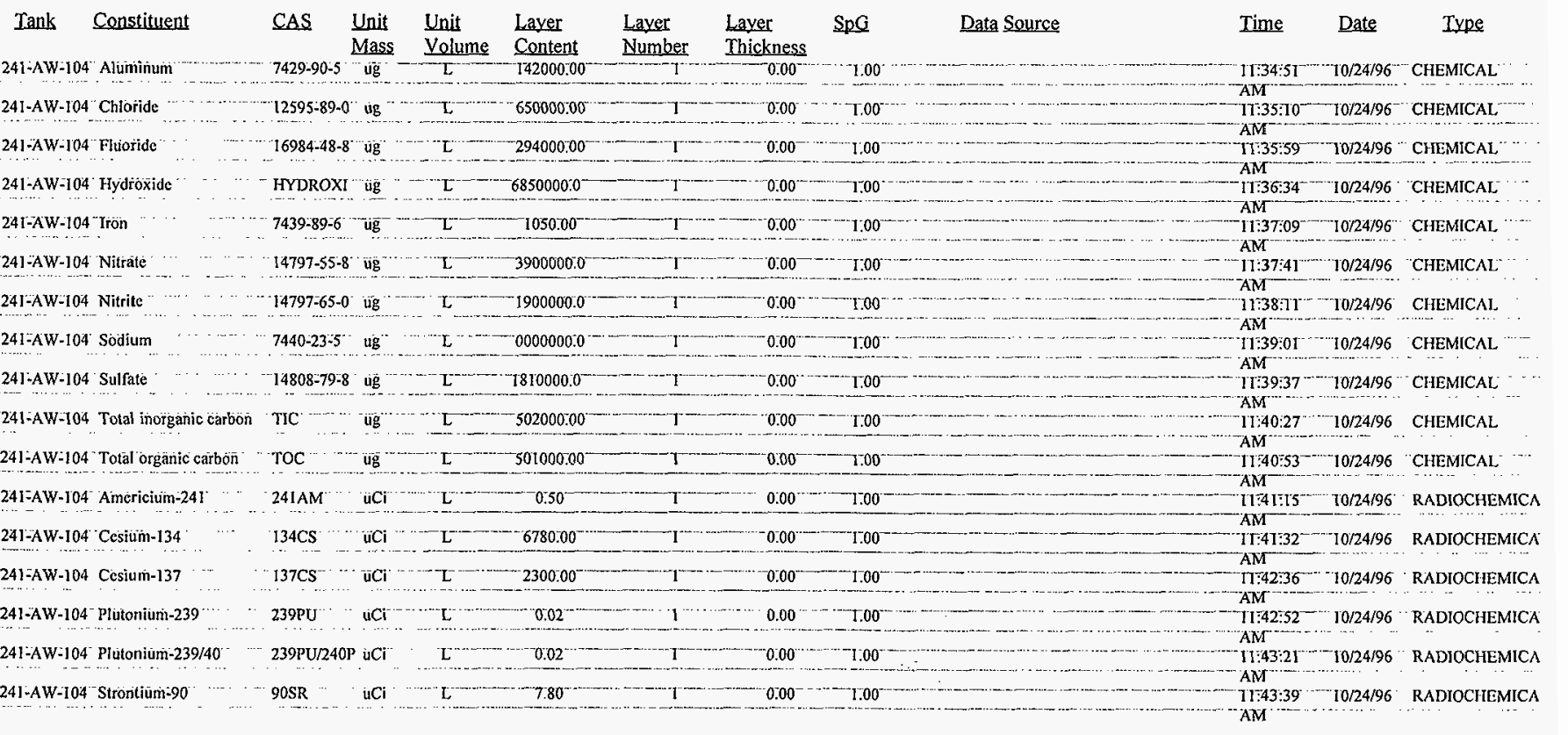




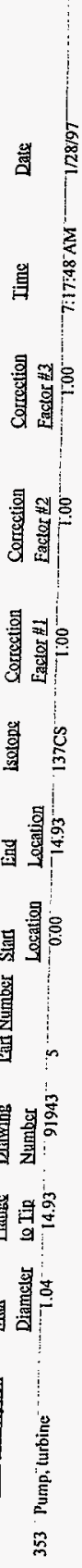


Length in meters

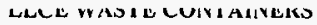

Weight in $\mathrm{kg}$

\begin{tabular}{|c|c|c|c|c|c|c|c|c|c|c|c|c|c|}
\hline \multicolumn{2}{|c|}{ Descriptio Container } & $\frac{\text { Centainer }}{\mathrm{D}}$ & $\begin{array}{l}\text { Containgr } \\
\text { Length }\end{array}$ & $\begin{array}{l}\text { Max LLCE } \\
\text { Diameter }\end{array}$ & $\frac{\text { Max LLCE }}{\text { Lengih }}$ & $\begin{array}{l}\text { Container } \\
\text { External } \\
\text { Yolume }\end{array}$ & $\begin{array}{l}\text { Container } \\
\text { Internal } \\
\text { Yolume }\end{array}$ & $\begin{array}{l}\text { Tarc } \\
\text { Weight }\end{array}$ & $\frac{\text { Containcr Drawing }}{\text { Number }}$ & $\begin{array}{l}\text { Skid Drawing } \\
\text { Number }\end{array}$ & Skid Weight & Time & Date \\
\hline LLCE-1 & $0.66^{\circ}$ & $0.6 \mathrm{I}^{-}$ & 15.85 & 0.29 & 14.33 & $-6.91^{\cdots}$ & 4.63 & 0.00 & ${ }^{-T_{B D}}{ }^{-\cdots}$ & 'TBD" ${ }^{-\cdots}-\cdots$ & 0.00 & $10: 53: 26 \mathrm{AM}^{-}$ & $8 / 22 / 96$ \\
\hline LLCE-2 & 0.66 & 0.61 & 21.34 & 0.29 & 19.81 & 9.31 & 6.23 & 0.00 & TBD & TBD & 0.00 & $" 10: 54: 28 \mathrm{AM}$ & $8 / 22 / 96$ \\
\hline LLCE-3 & 0.91 & 0.84 & 15.85 & 0.59 & 14.33 & $13.25^{\circ}$ & 8.75 & 0.00 & TBD & TBD & 0.00 & $\mathrm{I0}: 54: 50^{\circ} \mathrm{AM}$ & $8 / 22796$ \\
\hline LLCE-4 & 0.91 & 0.84 & $21: 34^{-}$ & 0.59 & $19.81^{-1}$ & 17.84 & 11.77 & 0.00 & TBD & $-\mathrm{TBD}^{-\cdots}$ & $0.00^{-}$ & I0:55:117AM & $-8 / 22 / 96$ \\
\hline LLCE-5 & 1.37 & 1.27 & 21.34 & 1.04 & 19.81 & $40: 14$ & 27.03 & 0.00 & $T B D$ & $\mathrm{TBD}^{-}$ & $100.00^{\circ}$ & $10: 55: 29$ AM & $-8 / 22 / 96$ \\
\hline LLCE-6 & 1.61 & 1.50 & 15.85 & 1.27 & $14.33^{-}$ & 40.96 & 28.05 & 0.00 & TBD & TBD" & $0.00^{-}$ & $70: 55: 50 \mathrm{AM}$ & $-8 / 22 / 96$ \\
\hline LLCE-7 & 1.61 & 1.50 & 21.34 & 7.27 & $* 19.81$ & 55.14 & 37.76 & 0.00 & TBD & TBD & $0.00^{-}$ & $10.56: 25 \mathrm{AM}$ & $8 / 22 / 96$ \\
\hline LLCE-8 & 1.71 & 1.68 & 21.34 & 1.52 & 19.81 & 62.05 & 47.09 & $0.00^{-}$ & TBD & TBD & 0.00 & $70: 56: 48 \mathrm{AM}$ & $-8 / 22 / 96$ \\
\hline LLCE-9 & 1.37 & 1.27 & 15.85 & 1.04 & $14.33^{-}$ & 29.82 & $20.08 \cdots$ & 0.00 & TBD & TBD & $0.00^{-}$ & $10: 57: 05 \mathrm{AM}$ & $-8 / 22 / 96$ \\
\hline
\end{tabular}


Lsotons Specific Half Lifs Heat Activity ycars Gencration Cilg

\begin{tabular}{|c|c|c|c|}
\hline $225 \mathrm{AC}$ & 58040.00 & $0.03^{-}$ & 0.03 \\
\hline $227 \mathrm{AC}$ & 72.34 & 21.77 & 0 \\
\hline $228 \mathrm{AC}$ & 2242000.00 & $0.00^{-}$ & 5.0 \\
\hline 24IAM & 3.43 & 432.52 & 0 \\
\hline $242 \mathrm{AM}$ & 808500.00 & 0.00 & \\
\hline $242 \mathrm{mAM}$ & -9.72 & $152.11^{-}$ & \\
\hline $243 \mathrm{AM}$ & 0.20 & 7385.21 & \\
\hline $217 \mathrm{AT}^{\circ}$ & 1000000000 & 0.00 & \\
\hline $133 \mathrm{BA}$ & $\therefore 250.30$ & $10.50^{\circ}$ & \\
\hline $137 \mathrm{mBA}$ & 5380000000 & 0.00 & \\
\hline 10BE & 0.02 & 1600000.0 & \\
\hline $210 \mathrm{BI}$ & 124100.00 & $0.0 \mathrm{I}^{-}$ & 0.0 \\
\hline $211 \mathrm{BI}^{-}$ & 418400000.0 & 0.0 & 9.0 \\
\hline $212 \mathrm{BI}$ & 146500 & 0.00 & 0.0 \\
\hline $213 B \mathrm{I}^{-}$ & 193400 & 0.0 & 0.0 \\
\hline $214 \mathrm{BI}^{\circ}$ & 4416000 & 0.0 & 0.0 \\
\hline $14 C^{\cdots}$ & 4.46 & 573 & 0.0 \\
\hline $113 \mathrm{mCD}$ & 216 & 13 & .0 \\
\hline $144 C E^{\prime}$ & 3190.00 & 0. & 0.0 \\
\hline $36 \mathrm{Cl}^{-}$ & 0.03 & 3010 & 0.0 \\
\hline $1242 \mathrm{CM}$ & 3307 & 0.4 & 0.0 \\
\hline & & 28. & 0.0 \\
\hline & 80.9 & 18.1 & 0.0 \\
\hline $245 \mathrm{CM}^{-}$ & 0.17 & 850 & 0.0 \\
\hline $246 \mathrm{CM}$ & 0.31 & 473 & .0 \\
\hline $247 \mathrm{CM}^{-1}$ & 0.00 & 56000 & 0.0 \\
\hline $248 \mathrm{CM}^{-}$ & 0.00 & $339000.0^{\circ}$ & 0.0 \\
\hline $60 \mathrm{CO}^{-}$ & 1131 & 5.27 & 0.0 \\
\hline $134 \mathrm{CS}$ & 1300 & $2.06^{\circ}$ & 0.0 \\
\hline $135 \mathrm{CS}$ & $-0,00$ & 23000 & 0.0 \\
\hline $137 \mathrm{CS}$ & $86.60^{\circ}$ & 30.17 & -0.0 \\
\hline I50EU & $66.21^{\circ}$ & 36 & 0.0 \\
\hline $152 \mathrm{EU}$ & 173. & 13. & 0.0 \\
\hline I54EU & -264 & 8.80 & 0.0 \\
\hline $155 E U^{\circ}$ & 465 & 4.96 & 0.0 \\
\hline $22 \mathrm{HFR}$ & 177300000.0 & 0.0 & 0.0 \\
\hline $223 F R^{\prime \prime}$ & 38680000.0 & 0.0 & 0.0 \\
\hline $152 \mathrm{GD}^{-}$ & 0.00 & $0000000 \cdots$ & 0.0 \\
\hline $\mathrm{I} 53 \mathrm{GD}$ & 3527.00 & 0.66 & 0.0 \\
\hline $3 \mathrm{H}^{-\cdots}$ & 965 t.00 & 12.28 & 0.0 \\
\hline [291 ${ }^{-}$ & $0.00^{-}$ & 5700000 & 0.0 \\
\hline $113 \mathrm{mIN}$ & 16730000.0 & $0.00^{2}$ & 0.0 \\
\hline $40 \mathrm{~K}^{-\cdots}$ & $0.00^{\circ}$ & $77000000^{\circ}$ & 0.0 \\
\hline $54 \mathrm{MN}^{-}$ & 7739.00 & 0.86 & \\
\hline $93 \mathrm{MO}$ & $1: 10^{-}$ & 3500 & 0.0 \\
\hline $93 \mathrm{mnB}$ & $282.70^{\circ}$ & $14.60^{\prime}$ & -0.0 \\
\hline $94 \mathrm{NB}$ & 0.19 & 20300.00 & 0.0 \\
\hline $95 \mathrm{mNB}$ & $39200.00^{\circ}$ & $0.10^{-}$ & 0.0 \\
\hline $95 \mathrm{NB}$ & 39110.00 & $0.10^{\circ}$ & 0.0 \\
\hline
\end{tabular}

Daughter Branching Daughter Branching Alpha Beta Gamma Fissile Hanford NRC 1 Ratio 12 Ratio 2 Emitt Emitter Emitter Material IRU IRU

Time Isolope Isotope

\begin{tabular}{|c|c|c|c|c|c|c|}
\hline $221 \mathrm{IFR}$ & 1.00 & $\mathrm{~N} / \mathrm{A}^{-}$ & $000^{\circ}$ & $1^{-}$ & $p^{\cdots \cdots}$ & \\
\hline 223FR & 0.01 & $227 \mathrm{TH}$ & $0.99^{-}$ & $t^{*}$ & $t$ & \\
\hline $228 \mathrm{TH}$ & 1.00 & $N / A^{-\cdots}$ & $0.00^{\circ}$ & 0 & I & \\
\hline $237 \mathrm{NP}$ & 1.00 & N/A & $0.00^{\circ}$ & 1 & 1 & \\
\hline $242 \mathrm{PU}$ & 0.17 & $242 \mathrm{CM}$ & 0.83 & 0 & $y$ & \\
\hline $238 \mathrm{NP}$ & 0.0 & $242 \mathrm{~A}$ & $1.00^{\circ}$ & 1 & 1 & \\
\hline $239 \mathrm{NP}$ & 1.00 & $\mathrm{~N} / \mathrm{A}^{-}$ & 0.00 & ? & $\mathrm{I}$ & \\
\hline $213 \mathrm{BI}$ & 1.00 & $\mathrm{~N} / \mathrm{A}^{-}$ & 0.00 & $i$ & 1 & \\
\hline$N / A^{-}$ & 0.00 & N/A & 0.00 & 0 & 1 & \\
\hline N/A & 0.00 & N/A & 0.00 & $0^{\circ}$ & $0^{\cdots--}$ & \\
\hline $\mathrm{N} / \mathrm{A}$ & 0.00 & N/A & $0.00^{\circ}$ & 0 & 0 & \\
\hline $210 \mathrm{PO}$ & 1.00 & $N / A^{-1}$ & 0.00 & 0 & & \\
\hline
\end{tabular}

\begin{tabular}{|c|c|}
\hline 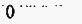 & \\
\hline $0^{-1.1 .}$ & $0^{-}$ \\
\hline$\cdots$ & -0 \\
\hline$\cdots \cdots$ & $\mathrm{T}$ \\
\hline 0 & 0 \\
\hline $1^{-\cdots}$ & $I$ \\
\hline$\cdots$ & 1 \\
\hline & 0 \\
\hline 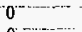 & 0 \\
\hline 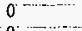 & $0^{\circ}$ \\
\hline
\end{tabular}
3:21:13 PM . $5 / 21796$ $21 \mathrm{~T} 4 \mathrm{PM}^{-\cdots}-5 / 21 / 96^{-\cdots} \mathrm{AC}$

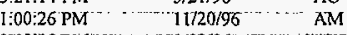
2:03:10 PM $\quad 8 / 23 / 96 \ldots \ldots$ AM 1:08:07 PM $\cdots 11 / 20 / 96^{\cdots} \cdots \cdots$ T:09.03 PM $-11 / 20 / 96 \cdots$

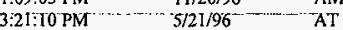
$3: 20: 58 \mathrm{PM}+5 / 21 / 96^{-\cdots}-3$

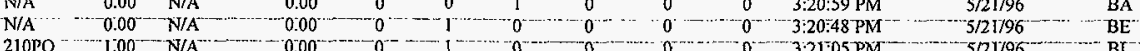

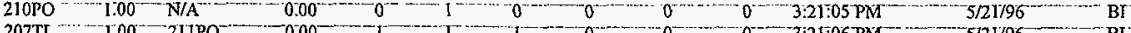

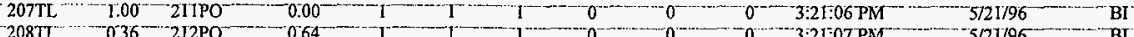

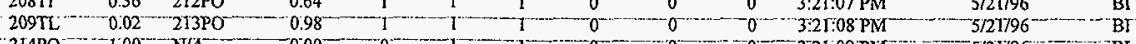

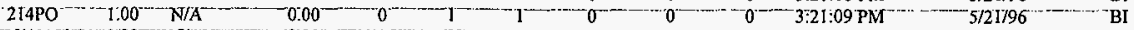

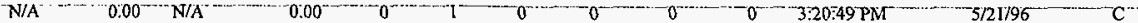

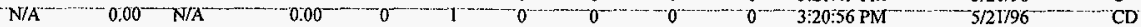

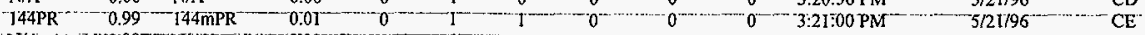

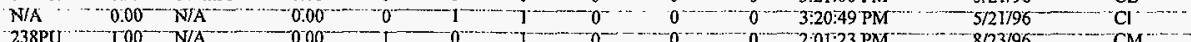

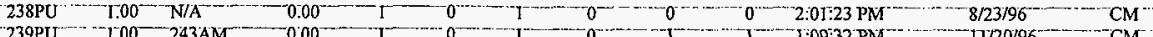

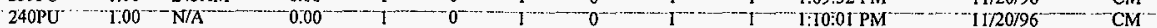

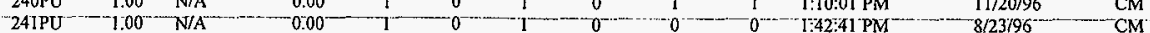

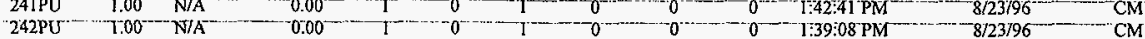

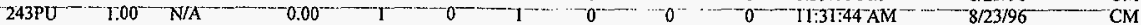

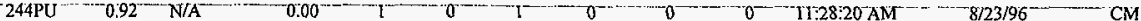

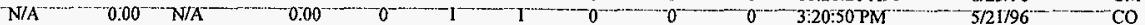

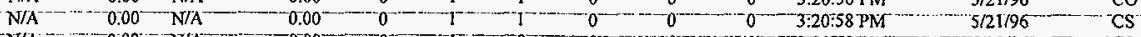

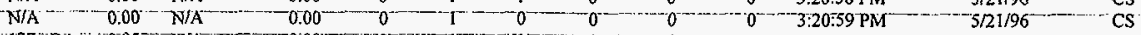

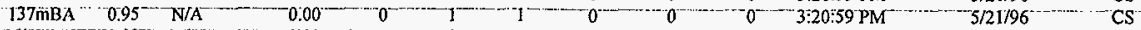

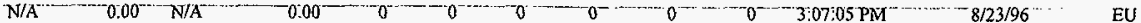

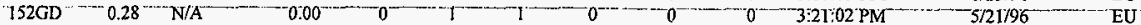

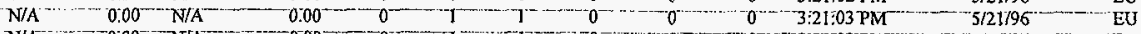

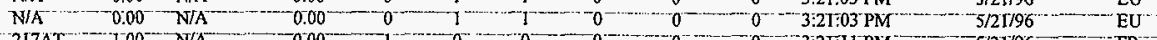

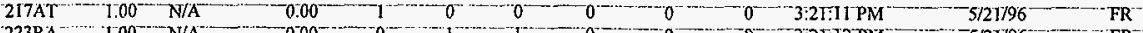

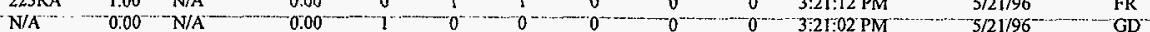

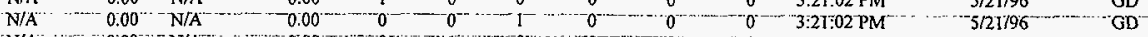

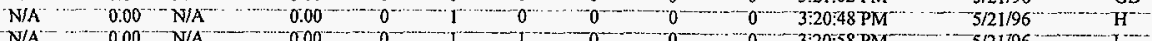

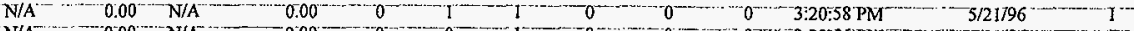

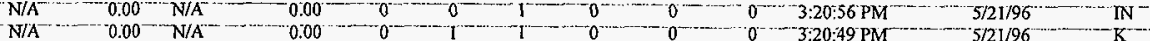

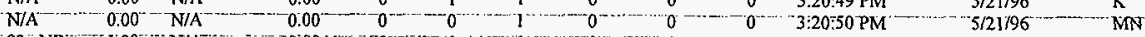

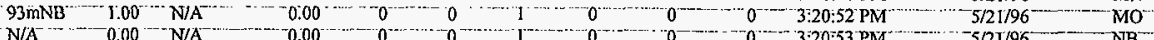

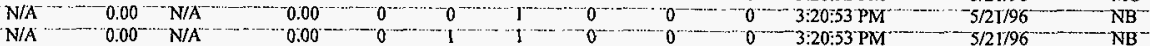

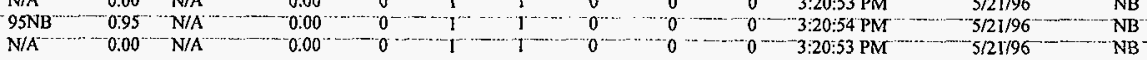


Isotope Specific HalfLifs Heal Activity years Gencration Ci/g

\begin{tabular}{|c|c|c|c|}
\hline $59 \mathrm{NI}^{-}$ & 0.08 & 75000.00 & \\
\hline 63NI & 61.69 & & \\
\hline $37 N P$ & $0.00^{\circ}$ & 2141362.2 & \\
\hline $38 \mathrm{NP}$ & 259200.00 & & \\
\hline $39 \mathrm{NP}$ & 232000.00 & & \\
\hline $10 \mathrm{mNP}$ & 105900000.0 & & \\
\hline $31 P^{-}$ & 0.05 & 327 & \\
\hline $3 \mathrm{PA}$ & 20760,00 & & \\
\hline $34 \mathrm{~m} P A$ & 6869000 & & \\
\hline $234 \mathrm{PA}$ & 1999000.00 & & \\
\hline 205PB & 0.00 & 5100 & \\
\hline $209 \mathrm{~PB}$ & 4544000.00 & & \\
\hline $10 \mathrm{~PB}$ & 76.35 & 22 & \\
\hline $1 \mathrm{~PB}$ & 246900 & & \\
\hline $2 \mathrm{~PB}$ & 13900 & & \\
\hline $4 \mathrm{~PB}$ & 32790000.0 & & \\
\hline 107PD & $0.00^{\cdots}$ & 6500 & \\
\hline $145 \mathrm{PM}$ & 139 & & \\
\hline 147PM & 928 & & \\
\hline O9PO & & & \\
\hline $10 \mathrm{PO}$ & $\quad 4490.00$ & 0.3 & \\
\hline JPO - & 5490000 & & \\
\hline $2 \mathrm{PO}$ & 00000 & & \\
\hline $213 \mathrm{PO}^{-}$ & 00000 & & \\
\hline $4 \mathrm{PO}$ & 90000 & & \\
\hline $15 \mathrm{PO}^{\circ}$ & 80000 & & \\
\hline 6PO- & 82000 & & \\
\hline $8 \mathrm{PO}^{\circ}$ & 282800 & & \\
\hline $144 \mathrm{mPR}$ & 18140 & 0. & \\
\hline APR & 7600000 & 0.0 & \\
\hline PU & 17.12 & & \\
\hline$P U$ & 0.06 & 240 & \\
\hline OPU & $-0.23-$ & 654 & \\
\hline $241 \mathrm{PU}^{-}$ & 103 & 14 & \\
\hline PU & 0.00 & $387 !$ & \\
\hline $243 \mathrm{PU}^{-}$ & 2603000.00 & & \\
\hline 244PU & 0.00 & 2600000 . & \\
\hline $3 \mathrm{RA}$ & $51220.00^{\circ}$ & 0.03 & \\
\hline $4 R A$ & $15930 \mathrm{C}$ & 0.0 & \\
\hline 225RA & -39210.00 & & \\
\hline $226 \mathrm{RA}$ & 0.99 & 1600.00 & \\
\hline 228RA & $234.10^{-}$ & $5.75^{-}$ & \\
\hline 187RE & $0.00^{-}$ & $00000000^{-}$ & \\
\hline 103MRH & 32530000.0 & $0.00^{\cdots}$ & \\
\hline $106 \mathrm{RH}^{-2}$ & 5600000 & 0.00 & \\
\hline 2I9RN & 3010000000 & & \\
\hline $220 \mathrm{RN}^{\circ}$ & $922400000.0^{\circ}$ & & \\
\hline $222 \mathrm{RN}$ & $-153800.00^{-}$ & 0.00 & \\
\hline & 32280.00 & 0.11 & \\
\hline
\end{tabular}

Daughter Branching Daughter Branching Alpha Beta Gamma Fissile Hanford NRC 1 Ratio 12 Ratio 2 Emitt Emitter Emitter Material TRU TRU

Isotope Isotope
Time

Date

Element

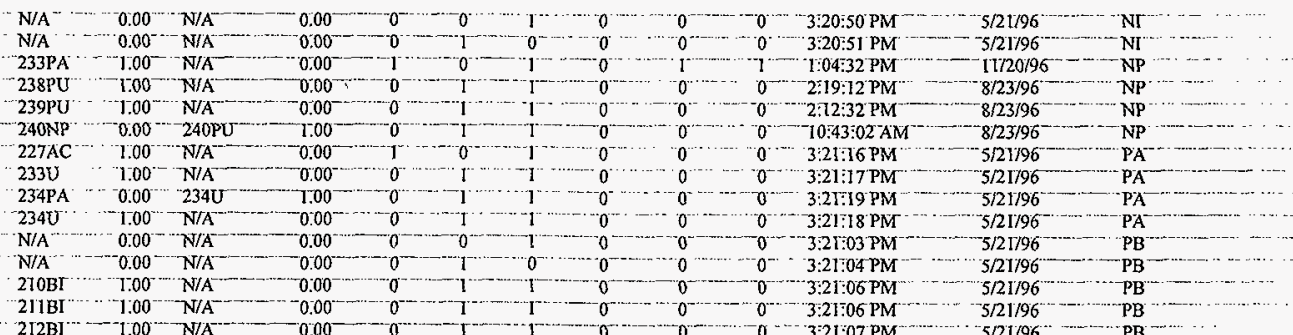

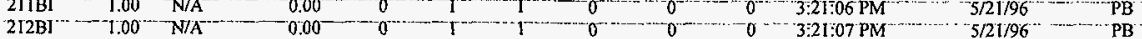

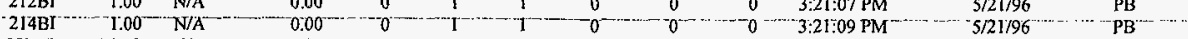

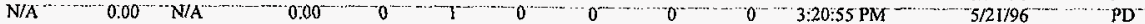

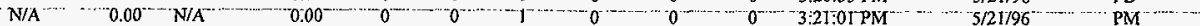

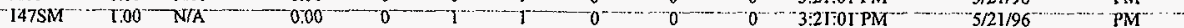

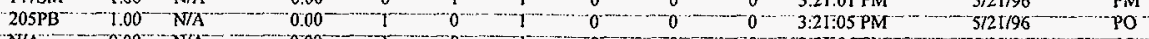

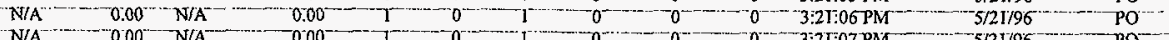

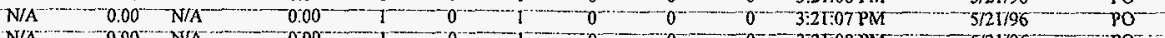

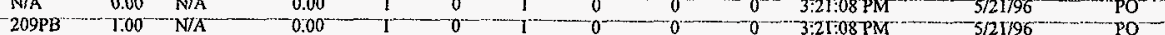

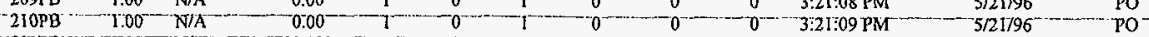

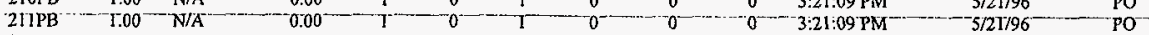

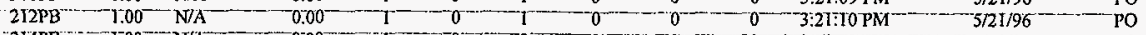

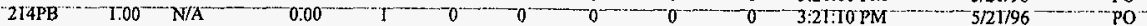

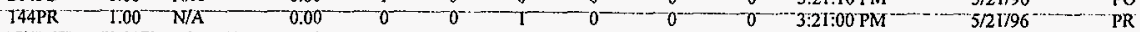

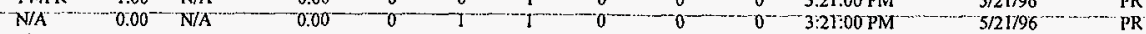

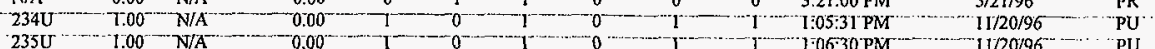

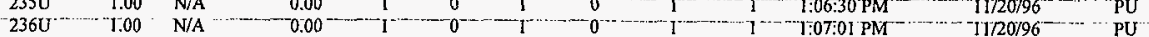

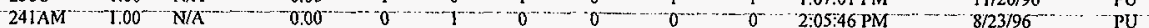

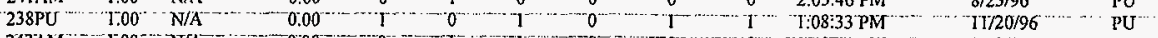

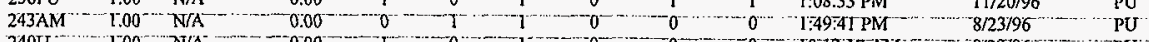

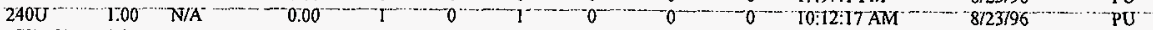

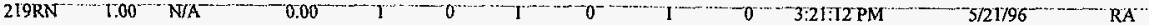

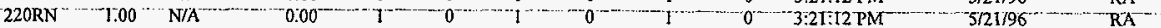

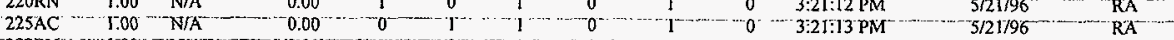

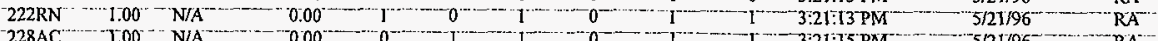

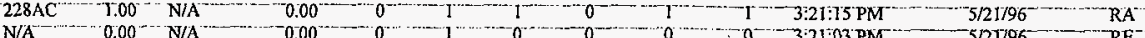

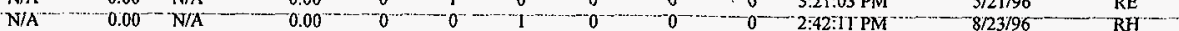

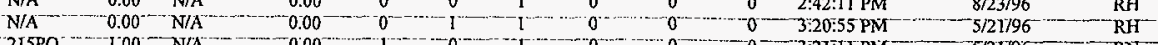

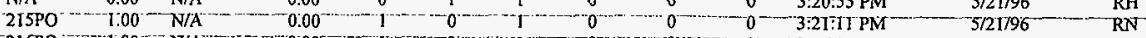

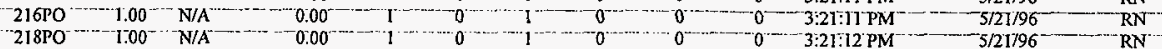

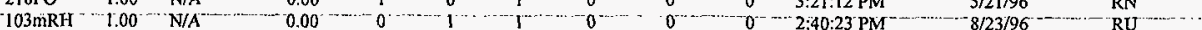




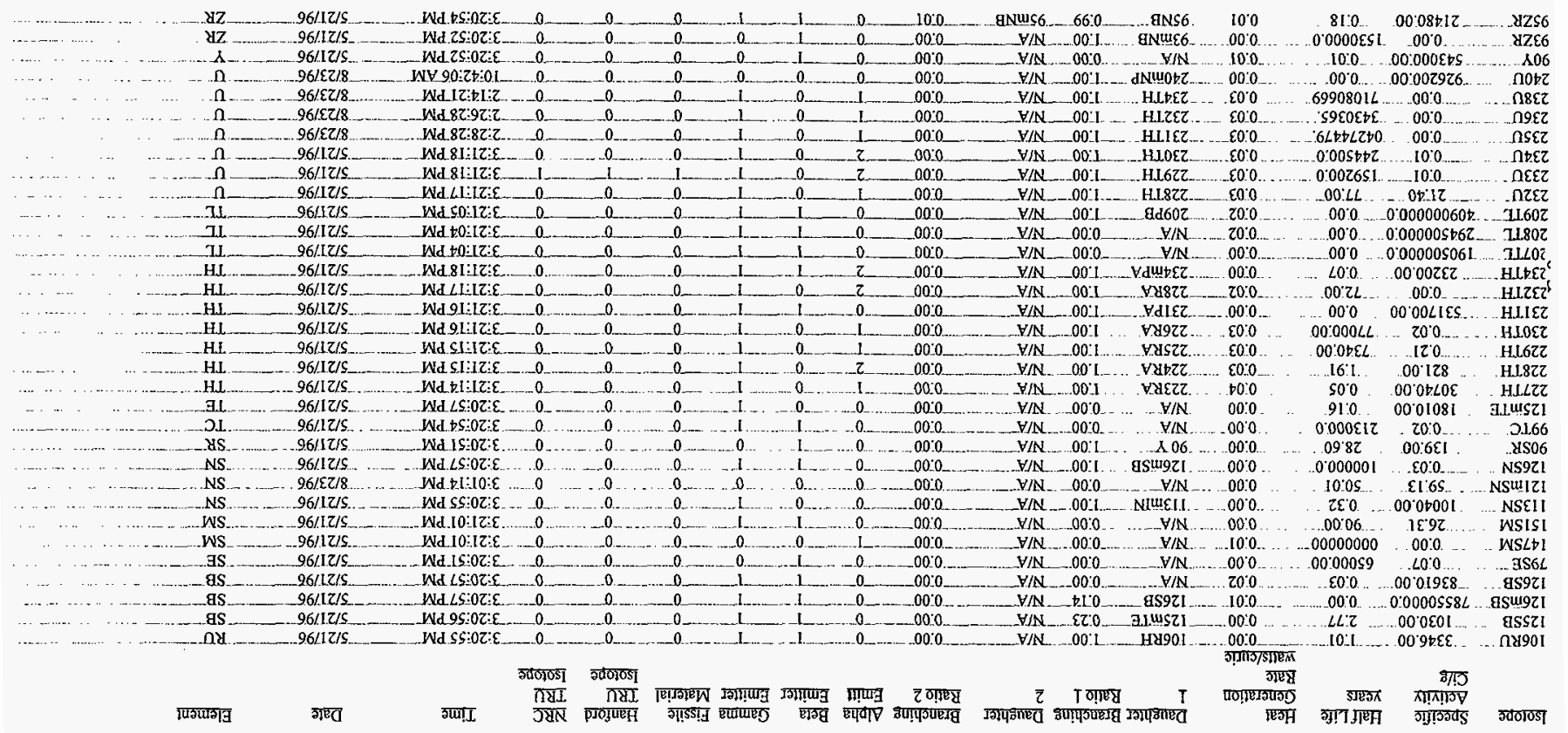




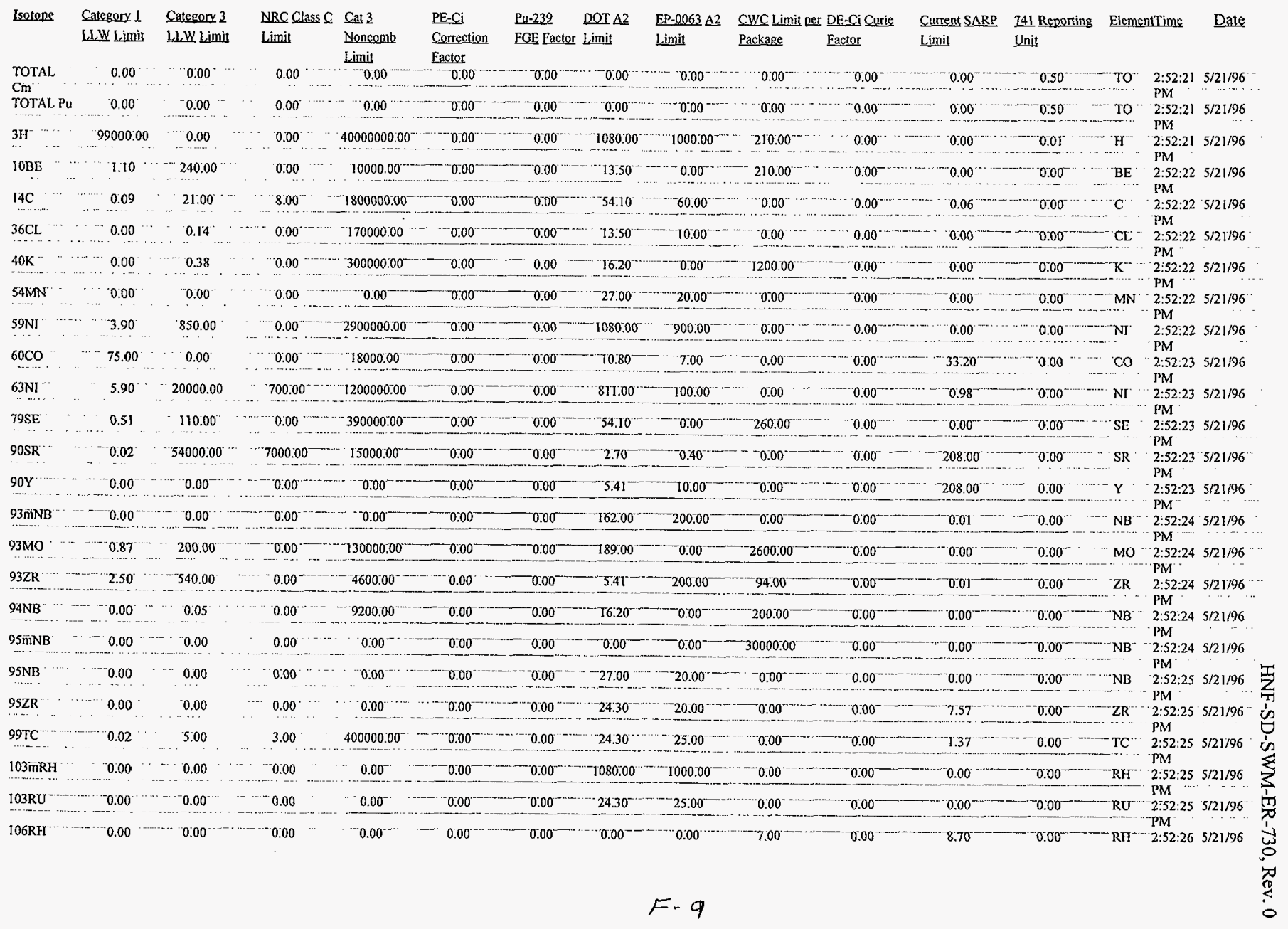




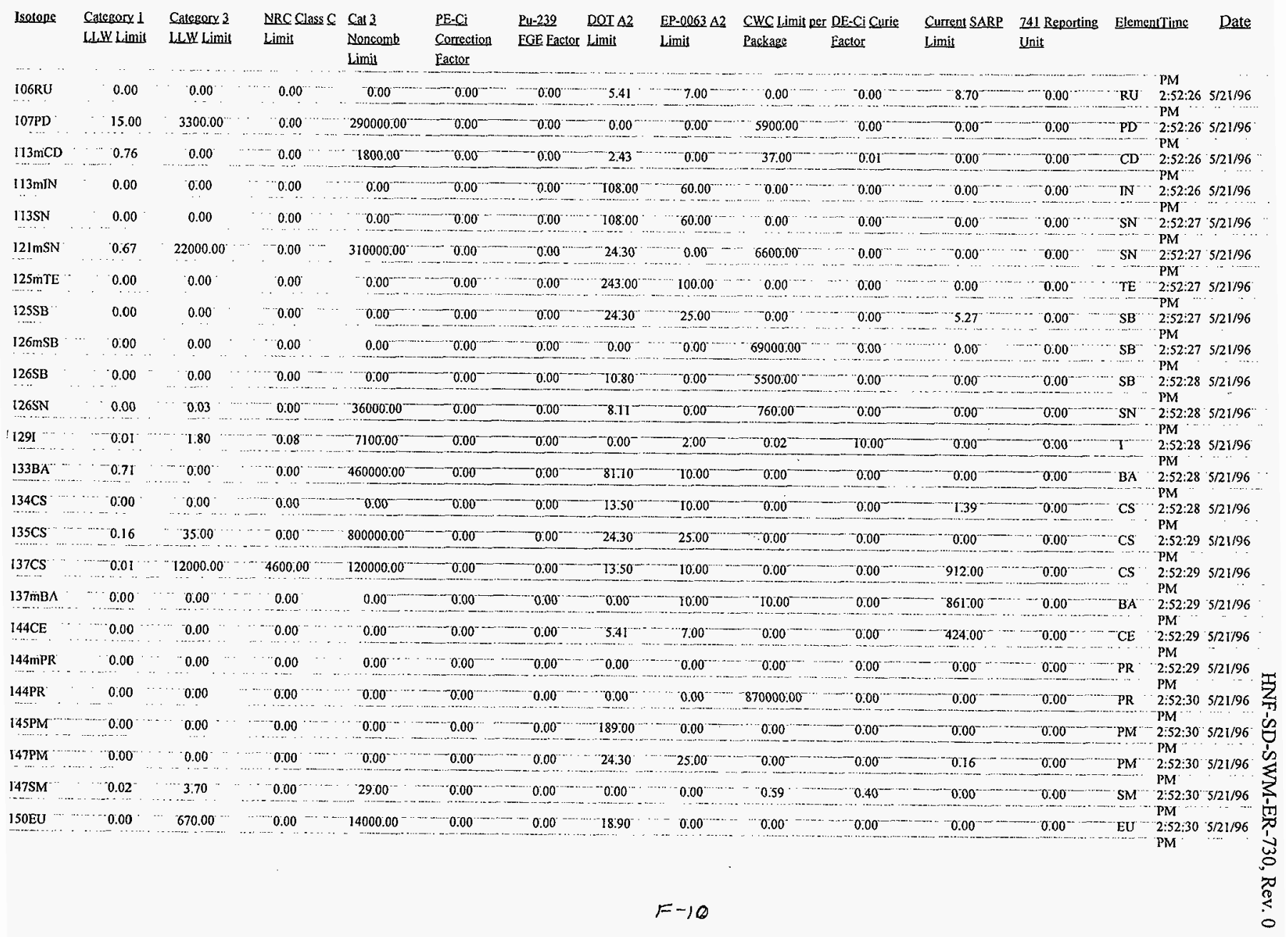




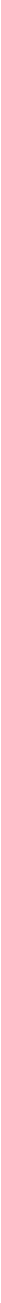




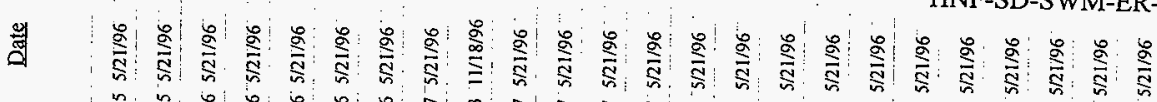

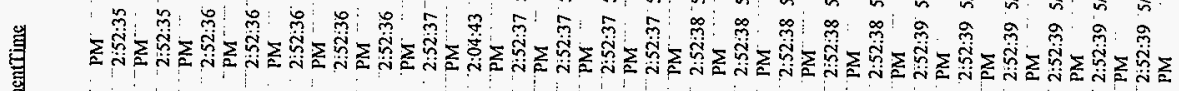

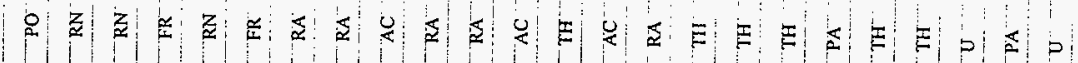

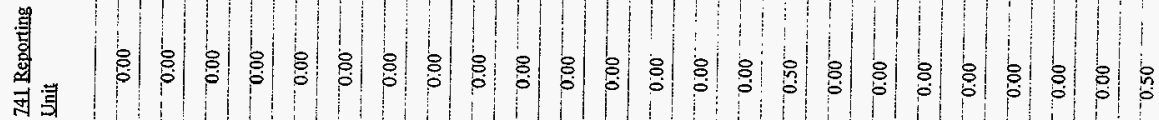
氧 잉

武氧 벽 영 ○) 궁 司 司苟 영 弐萄意 矛苟自 设 \% 偂격 貮

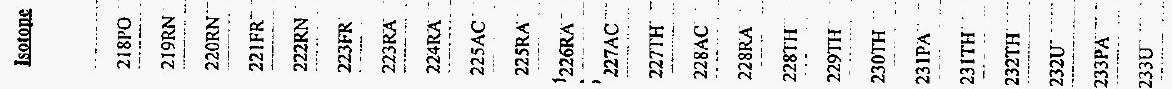




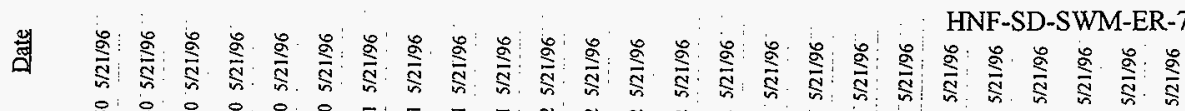

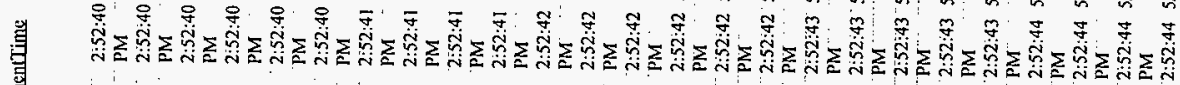

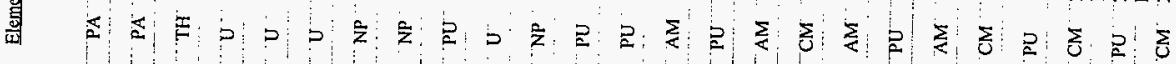

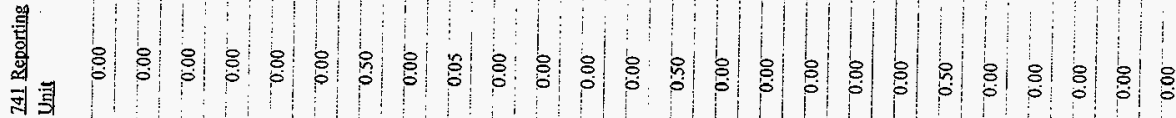
인 武自 岛 념

武罒

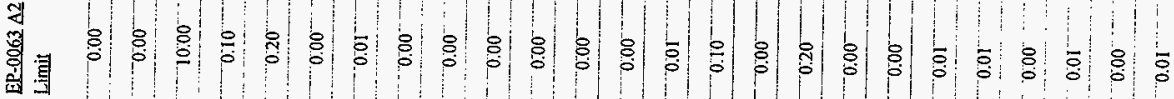

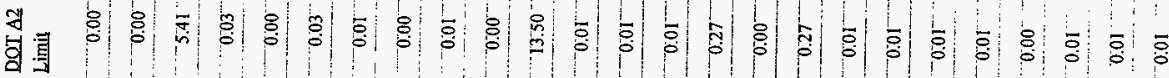

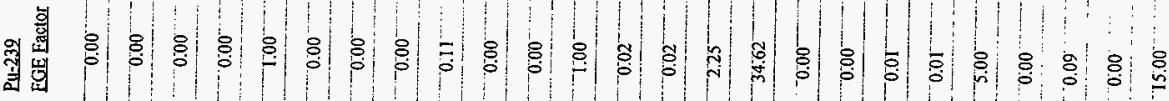

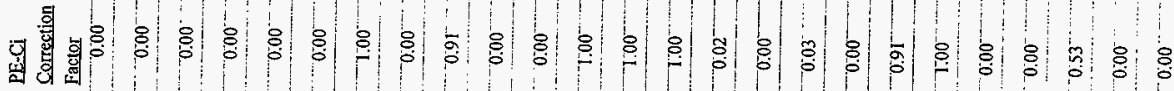

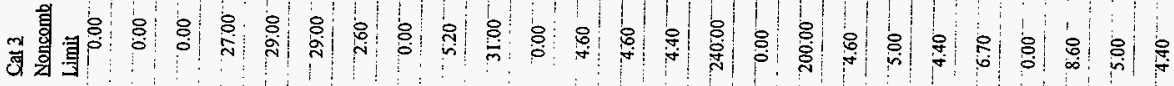
畜:

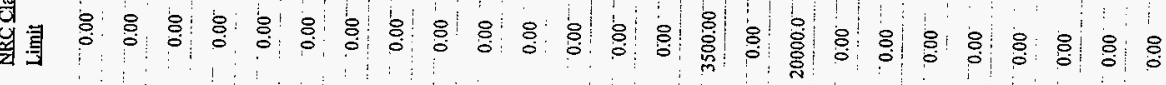
武青 牙整

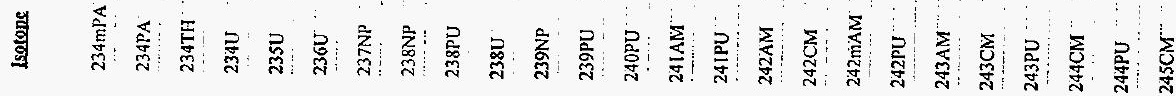


苟

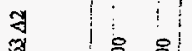

봼격

各自

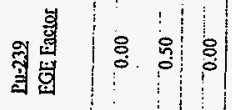

벽영영

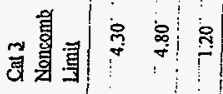

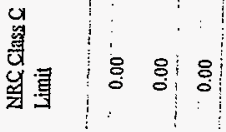

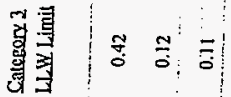

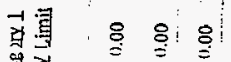

娄寻, ․

蔥: 


\begin{tabular}{|c|c|c|c|c|c|}
\hline Constituent Name & CAS & D Code & $\begin{array}{l}\mathrm{D} \text { Code Limit } \\
(\mathrm{mg} / \mathrm{L})\end{array}$ & Time & Date \\
\hline Arsenic & $7440-38-2$ & DN04 & 33.75 & T:SI:00PM & $-5 / 21 / 96$ \\
\hline Barium & $7440-39-3$ & D005 & 100.00 & T:5ा:00PM & $5 / 21 / 96$ \\
\hline Cadium & $7440=43-9$ & D006 & T.00 & T:Sा:00PM & $5 / 21796$ \\
\hline Chromium & $7440-47-3$ & D007 & 1.00 & T:51:00PM & $5721 / 96$ \\
\hline Lead & $7439 \times 92-1$ & Do08 & 700 & I:ST:00PM & $5 / 21 / 96$ \\
\hline Mercury & $7439-97-6$ & Doos & 0.20 & $1: 51500 \mathrm{PM}$ & $5727 / 95$ \\
\hline Selenium & $7782-49-2$ & DOTO & $1.00^{\circ}$ & T:ST:00PM & $5 / 21 / 96$ \\
\hline Silver & $7440-224$ & Dणा & 5.00 & I2:23:07PIM & $8 / 22 / 96$ \\
\hline
\end{tabular}




\section{LLCE WASTE CHARACTERIZATION SUMMARY REPORT}

\section{UserNamo: sat}

LLCE Description: Pump, turbine

Drawing Number (H-2): 91943

Part Number. 5

Wasto Tank: 24!-AW-104

Tank Riser: 1

Waste Container: 5

\section{CHECK TO SEE IF SARP LIMITS HAVE BEEN EXCEEDED}

No SARP Limits have been exceeded.

SEP is not required for thls waste package

\section{CALCULATE FOR CAT 1 AND CAT 3 LLW}

Volume for LLCE waste container: 5 is $2.7028 \mathrm{e}+1 \mathrm{~m}^{\wedge} 3$

Cat I Sum of fractions is : $3.5736 \mathrm{e}-1$

Cat 3 Sum of fractions is : $7.3316 \mathrm{e}-7$

NRC Class C Sum of fractions is : $42747 \mathrm{e}-7$

Cat 3 Noncombustable Linit Sum of fractions is : 12015e-7

LLCE waste is Category 1, LLMW

LLCE is suitable for near surface disposal (NRC C Fraction < 1)

Additional safety analysis is not reguired for near surface disposal. (NonComb Fraction <1)

\section{TRU WASTE CALCULATION}

LCE Weight is $\mathrm{t}$.e+3 $\mathrm{kg}$

LLCE waste is Low Level Mixed Waste (LLMW) since TRU fraction <1 (1.2323e-4)

LLCE waste in not Greater than NRC Class C since NRC fraction $<1$ (1.2323e-4)

\section{CALCULATE PE-Ci FOR TRU WASTE}

Since LICE waste is not TRU this calculation is not reguired.

CALCULATE PU-239 FGE FOR TRU WASTE

Since LLCE waste is not TRU this calculation is not required.

\section{CALCULATE ALPHA CURJE CONTENT FOR TRU WASTE}

Since LLCE waste is not TRU this calculation is not required.

\section{CALCULATE FOR ACCOUNTABLE NUCLEAR MATERIAL}

LCE waste does not contain accountable nuclear materiat.

HEAT GENERATION FROM THE LLCE WASTE PACKAGE

Total heat generated by LLCE waste is: $1.6481 \mathrm{e}-3$ watts. Internat Volume of selected Contsiner LLCE-5 $=9.5449 \mathrm{e}+2 \mathrm{ft}^{\wedge} 3$

Heat Generarion rase for this LLCE waste is $1.7267 e-6$ watts/ $/ A^{\wedge} 3$

Heat Generation rate doesn't exceed 0.1 watts/f^3

CALCULATE TRANSPORTATION CATEGORY :,

A2 Fraction Sum $=1.7856 t-2$

EP-0063 Appendix L A2 Linit Frection = 2,3206e-2

L.CCE Waste Package is Type A Quantity.

DECi Calculation is not required.

\section{CALCULATE DE-Ci}

DE-Ci Calculation is not required according to transportation category.

\section{CALCULATE HAZARDOUS WASTE CODES}

Hazardous waste codes F001-F005 apply to all LLCE.

No other Waste codes Apply.

\section{LLCECALC PROGRAM TEST RUN}

Note: Test run was performed for tank 104-AW using gamma assay data gathered by Project W-151 retrieval efforts on Tank 241-AZ-101 


.




\section{ESTIMATED RADIONULIDE/CHEMICAL CONTENT OF LLCE WASTE}

content estimated to be: $1.3564 \mathrm{e}-7 \mathrm{C}$

Aluminum content extimated to be: $32739=0 \mathrm{~g}$

Chloride content estimated to be: $1.4986 \mathrm{et} \mathrm{g}$

Fluoride content estimated to be: $6.7785 \mathrm{e}+0 \mathrm{~g}$

Hydroxide content estimated to be: $1.5793 \mathrm{e}+2 \mathrm{~g}$

Iron content estimated to be: $2.4209 \mathrm{e}-2 \mathrm{~g}$

Nitrate content estimated to be: $5.5104 \mathrm{e}+2 \mathrm{~g}$

Nitrite content estimated to be: $2.7437 \mathrm{e}+2 \mathrm{~g}$

Sodium content extimated to be: $2.3056 \mathrm{e}+2 \mathrm{~g}$

Sulfate content estimated to be: $4.1731 \mathrm{e}+\mathrm{g}$

Total inorganic carbon content estimated to be: $1.1574 \mathrm{e}+1 \mathrm{~g}$

Total organic carbon content estimated to be: $1.1551 \mathrm{e}+\mathrm{g}$

Americium-241 content estimated to be: $1.1574 \mathrm{e}-5 \mathrm{C}$;

Cesium-134 content estimated to be: $1.5632 \mathrm{e}-1 \mathrm{Ci}$

Cesium-137 content estrmated to be: $5.3029 \mathrm{e}-2 \mathrm{Ci}$

Plutonium-239 content estimated to be: $6.1368 \mathrm{e}-7 \mathrm{Ci}$

Strontlum-90 content estimated to be: $1.7984 \mathrm{e}-4 \mathrm{Ct}$

\section{CALCULATED WASTE CONTENT VS SARP LIMIT}

LLCE Waste Content: 1.1574e-5 for Americium-241 SARP Limit is: $3.67 \mathrm{e-1} \mathrm{Ci}$ LLCE Waste Content: 1.5632e-1 for Cesium-134 SARP Limit is: $1.39 \mathrm{et} 0 \mathrm{C} i$ LCCE Waste Content: $5.3029 \mathrm{e}-2$ for Cesium-137 SARP Limit is: $9.12 \mathrm{e}+2 \mathrm{Ci}$ LLCE Waste Content: 6.1368e-7 for Plutonium-239 SARP Limit is: $4 . e-1 \mathrm{Ci}$ LLCE Waste Content: $1.7984 e-4$ for Strontium-90 SARP Limit is: $2.08 \mathrm{e}+2 \mathrm{Ci}$ LLCE Waste Content: 1.3564 e-7 for SARP Limit is: $1.86 e-2 \mathrm{Ci}$

\section{CALCULATE FOR CAT 1 AND CAT 3 LLW}

Isotope, CAT 1 Frection, CAT 3 Fraction, NRC Class $\mathrm{C}$ fraction, NonComb Limit Fraction $241 A M, 2.0392 e-4,5.038 e-7,0 . e+0,9.7325 e-8$

I3ACS, $0 . e+0,0 . e+0,0 . e+0,0 . e+0$

$137 \mathrm{CS}, 3.5673 \mathrm{e}-1,1.635 \mathrm{e}-7,4.2652 \mathrm{e}-7,1.635 \mathrm{e}-8$

239PU, 1.195e-5, 5.4061e-8, $0 . e+0,4.936 e-9$

$90 S R, 4.1586 \mathrm{e}-4,1.2322 \mathrm{e}-10,9.5054 \mathrm{e}-10,4.4358 \mathrm{e}-10$

$240 P U, 2.6413 \mathrm{e}-6,1.1671 \mathrm{e}-8,0 . \mathrm{e}+0,1.091 \mathrm{e}-9$

Cat 1 Sum of tractions is : $3.5736 \mathrm{e}-1$

Cat 3 Sun of fractions is : $7.3316 \mathrm{e}-7$

NRC Class C Sum of fractions is : $4.2747 \mathrm{e}-7$

Cat 3 Noncombustable Limit Sum of fractions is : $1.2015 \mathrm{~s}-7$

LLCE waste is Category L, LLMW

LLCE is suitable for near surface disposal (NRC C Fraction < 1 )

Additional safety analysis is not required for near surface disposal. (NonComb Fraction <1)

\section{TRU WASTE CALCULATION}

\section{LLCE Weight is $1 . e+3 \mathrm{~kg}$.}

241 AM is a NRC TRU isotope

Content $=1.1574 \mathrm{e}-2 \mathrm{nCi} / \mathrm{gram}$

Fraction $=1.1574 \mathrm{e}-4$

241AM is a Hanford TRU isotope

Content $=1.1574 \mathrm{e}-4 \mathrm{nCV}$ /gram

Fraction $=1.1574 \mathrm{e}-4$

$239 \mathrm{PU}$ is a NRC TRU isotope

Content $=6.1368 \mathrm{e}-4 \mathrm{nCi} / \mathrm{gram}$

Fraction $=6.1368 \mathrm{e}-6$

239PU is a Hanford TRU isotope

Content $=6.1368 \mathrm{e}-6 \mathrm{nCi} / \mathrm{gram}$

- Fraction $=6.1368 \mathrm{e}-6$

240PU is a NRC TRU isotope

Content $=1.3564 e-4 \mathrm{nCV} / \mathrm{gram}$

Fraction - 1.3564c-6

240PU is a Hanford TRU isorope

Content $=1.3564 \mathrm{e}-6 \mathrm{nCi} / \mathrm{gram}$

Fraction - $1.3564 e-6$

LLCE waste is Low Level Mixed Waste (LLMW) since TRU fraction <1 (1.2323e-4)

LLCE waste in not Greater than NRC Class C since NRC fraction <1 (1.2323e-4) 
CALCULATE PE-CI FOR TRU WASTE

Since LLCE waste is not TRU this calculation is not required.

CALCULATE PU-239 FGE FOR TRU WASTE

Since LLCE waste is not TRU this calculation is not required.

CALCULATE ALPHA CURIE CONTENT FOR TRU WASTE

Since LLCE waste is not TRU this calculation is not regulred.

CALCULATE FOR ACCOUNTABLE NUCLEAR MATERIAI

LLCE waste does not contain accountable nuclear material.

HEAT GENERATION FROM THE LLCE WASTE PACKAGE

lsotope, Curies, Wetts/Ci, Watts

- 241AM, $1.15740-5,3.322 e-2,3.84490-7$

$134 C S, 1.5632 \mathrm{e}-1,1.02 \mathrm{e}-2,1.5945 \mathrm{e}-3$

$137 \mathrm{CS}, 5.3029 \mathrm{e}-2,1 . e-3,5.3029 t-5$

239PU , 6.1368e-7, 3.082e-2, $1.8914 \mathrm{e}-8$

90SR, 1.7984e-4, 1.2e-3, 2.158e-7

$240 \mathrm{PU}, 1.3564 \mathrm{c}-7,3.114 \mathrm{c}-2,4.2238 \mathrm{c}-9$

Total heat generated by LLCE waste is: 1.6481e-3 watts.

Internal Volume of selected Container LLCE- $5=9.5449 c+2 \mathrm{f} \wedge 3$

fiear Generation rate for this LLCE waste is $1.7267 \mathrm{c}-6$ watts/t/3

Heat Generation rate doesn't exceed 0.1 watts/f^ 3

\section{CALCULATE TRANSPORTATION CATEGORY}

Isotope, A2 Limit , EP-0063 A2 Limit, A2 Fraction, EP-0063 A2 fraction $241 \mathrm{AM}, 5.4 \mathrm{e}-3$, , 8.e-3, 2.1434e-3; $1.4468 \mathrm{e}-3$

134CS, 1.35e+1, , 1.et1, 1.1579e-2, 1.5632e-2

$137 \mathrm{CS}, 1.35 \mathrm{e}+1,1 . \mathrm{et1}, 3.9281 \mathrm{e}-3,5.3029 \mathrm{e}-3$

239PU, 5.4e-3, , 2.e-3, 1.1364e-4, 3.0684e-4

90SR, 2.7e+0, , 4.e-1, 6.6606e-5, 4.4959e-4

240PU, 5.4e-3, , 2.e-3, 2.5118e-5, 6.7819e-5

A2 Fraction Sum $=1.7856 \mathrm{e}-2$

EP-0063 Appendix L A2 Limit Fraction $=2,3206 \mathrm{e}-2$

LLCE Waste Package is Type A Quantity.

DECA Calculation is not required.

CALCULATE DE-Ci

DE-Ci Calculation is not required according to transportation category.

CALCULATE HAZARDOUS WASTE CODES

Hazardous waste codes F001-FOOS apply to all LLCE.

No other Waste codes Apply. 
1/27/97 - 4:51:25 PM:

I/27/97 - 4:51:25 PM: START OF LLCEDATA

$1 / 27 / 97$ - 4:51:25 PM:

1/27/97 - 4:51:26 PM: New Program Run initiated

1/27/97 - 4:51:26 PM: Program User is: $s d r$

1/27/97 - 4:51:26 PM: Main database file LLCEINFO.MDB open

1/27/97 - 4:51:27 PM: All changes made to database will be recorded (logged) in DBCHANGEMDB

1/27/97 - 4:51:27 PM: New LLCE Data File c:llicedataltest.cdf has been created and opened

1/27/97 - 4:51:28 PM:

1/27/97 - 4:52:04 PM: START - CHANGES to LLCE Physical Database Follow:

127/97 - 4:52:22 PM: END - LLCE Physical Database Changes

1/27/97 - 4:52:22 PM:

1/27/97 - 4:52:51 PM: START - CHANGES to LLCE Physical Database Follow:

1/27/97 - 4:53:05 PM: Pump, turbine, H-2-91943, H-9-1105, Part No: S, hes been selected for retrieval.

1/27/97 - 4:53:05 PM: Note that all units are in meters and $\mathrm{kg}$.

1/27/97 - 4:53:07 PM: END - LLCE Physical Database Changes

1/27/97 - 4:53:07 PM:

1/27197 - 4:55:17 PM: START - Eoliting of Tank Waste Data

1/27/97 - 4:55:17 PM: Tank 241-AW-104 was selected for Pump, turbine setrieval,

1/27/97 - 4:55:18 PM: LLCE will be retrieved from riser $\# 2$

1/27/97 - 4:55:20 PM: Type changed to: CHEMICAL

1/27/97 - 4:55:20 PM: Layer changed to: 1

1/27/97 - 4:57:14 PM: Specific Gravity was: 0.996 Now: 0.996

1/27/97 - 4:58:31 PM: Type changed to: RADIOCHEMICAL

1/27/97 - 4:59:47 PM: END - Editing of tank Waste Data

$1 / 27 / 97$ - 4:59:48 PM:

1/27/97 - 5:02:24 PM: START - Editing of Tank Waste Data

1/27/97 - 5:02:25 PM: Tank 241-AW-104 was selected for Pump, turbine retrieval.

1/27/97 - 5:02:25 PM: LLCE will be retrieved from riser \#5

1/27/97 - 5:02:26 PM: Current tank waste data accepted without editing

1/27/97 - 5:02:26 PM: END - Tenk Waste Data Editing

1/27/97 - 5:02:27 PM:

1/27/97 - 5:02:39 PM: START - Changes to Geometry contection factors for Pump, turbine

1/27/97 - 5:03:53 PM: New Record added for Isotope: 137CS At End Point: 10.

1/27/97 - 5:04:45 PM: New Record added for Isotope: 137Cs At End Point: I1.

1/27/97 - 5:05:05 PM: New Record added for Isotope: 137C\$ At End Poirt: 14.9289

1/28/97 - 7:03:38 AM:

1/28/97 - 7:03:39 AM: START OF LLCEDATA

1/28/97 - 7:03:39 AM:

1/28/97 - 7:03:40 AM: New Program Run Initiated

1/28/97 - 7:03:41 AM: Program User is: sdr

L/28/97 - 7:03:41 AM: Main database file LLCENFOMDB open

1/28/97 - 7:03:42 AM: All changes made to database will be recorded (logged) in DBCHANGE.MDB

1/28/97 - 7:03:42 AM: Existing LLCE Data File cill lcedataltest.edf has been Opened - Last Edited: 1/27/97

1/28/97 - 7:03:43 AM: Lest Program User Was: sdr

1/28/97 - 7:03:43 AM;

1/28/97 - 7:04:25 AM: START - CHANGES to LLEE Physical Database Follow:

1/28/97 - 7:07:39 AM: Cancel executed: Changes identified above have not been made

1/28/97 - 7:07:40 AM: END - LLCE Physical Database Chaihges

1/28/97 - 7:07:41 AM:

1/28/97 - 7:07:53 AM: START - Editing of Tank Waste Date

12897 - 7:07:54 AM: Tank: 241-AW-104 Tank Waste Data Being Edited.

1/28197 - 7:07:56 AM: Type changed to: CHEMICAL

1/28/97 - 7:07:56 AM: Layer changed to: 1

1/28/97 - 7:08:14 AM: Restoring Data for Tank 241-AW-104 in the LLCE Data File.

1/28/97 - 7:08:14 AM: END - Edixing of tank Waste Data

1/28/97 - 7:08:15 AM:

1/28:97 - 7:16:L 1 AM: START - Editing of Tank Waste Data

in8:97 - 7:16:12 AM: Tank 24t-AW-j04 wes sefected for Pump, turbine tetrieval.

1/2897 - 7:16:12 AM: LLCE will be retrieved from riser \#2

1/28/97 - 7:16:13 AM: Layer changed to: 1

1/28/97 - 7:17:06 AM: END - Editing of tank Waste Data

1/28197 - 7:17:07 AM:

1/28:97 - 7:17:39 AM: START - Editing of Tank Waste Data

1/28197 - 7:17:39 AM: Tank 241-AW-104 was selected for Pump, turbine retrieval.

1/28/97 - 7:1 7:40 AM: LLCE will be retrieved from riser \#1

1/28/97 - 7:17:40 AM: Curent tank waste dals accepted without editing

1/28/97 - 7:17:41 AM: END - Tank Waste Date Editing

1/28/97 - 7:17:42 AM:

1/28/97 - 7:17:48 AM: START - Changes to Ceometry correction factors for Purap, twrbine

1/28/97 - 7:20:24 AM: New Record added for Isotope: 137CS At End Point: 14.9289 
1/28/97 - 7:20:50 AM: END - Completed Geometry Correction factors

1/28:97 - 7:20:50 AM:

1/28/97 - 7:26:45 AM: Start - Completion of LLCE Data File

1/28/97 - 7:26:46 AM: Date for Conminer \#5 Saved to LLCE Data File

1/28/97 - 7:26:47 AM: D-Code Chemical Limits Saved to LLCE Data Fite

1/28/97 - 7:26:48 AM: Verified - Valid Gamma Isotope List is in LLCE Data File

1/28/97 - 7:26:52 AM: Radionuclide Limits Saved to LLCE Data File

1/28/97 - 7:26:56 AM: LLCE Data File Succesfully Completed

1/28:97 - 7:26:57 AM:

1/28/97 - 7:28:52 AM: BEGIN - Start of edit of Radionuclide Physical Constants

1/28/97 - 7:44:27 AM: END - end of edit of Radionuclide Physical Constants

1/28/97 - 7:44:27 AM:

1/28/97 - 7:44:36 AM: START - Begin edit of Radionuclide Regulatory Limits

1/28/97 - 7:50:10 AM: END - End edit of Radionuclide Regulatory Limits

1/28:97 - 7:50:11 AM:

1/28/97 - 7:51:13 AM: START - CHANGES to D-Code Regulatory Limits

1/28/97 - 7:52:17 AM: END - CHANGES to D-Code Regulatory Limits

1/28/97 - 7:52:18 AM:

1/28/97 - 7:S2:23 AM: START - CHANGES to List of Valid Measured Gamna Radionuclides Follow:

1/28/97 - 7:52:54 AM: END - CHANGES to List of Valid Measured Gamma Radionuclides Complete

1/28/97 - 7:52:55 AM:

I/31/97 - 7:48:07 AM:

1/31/97 - 7:48:07 AM: START OF LLCECALC

1/31/97 - 7:48:08 AM:

1/31/97 - 7;48:08 AM: LLCE Data File Selected: cillcedataltest.edf

1/31/97 - 7:48:09 AM: Gamma Assay File Selected: c:Vloccalclazl 3a.av2

I/31/97 - 7:48:09 AM:

1/31/97 - 8:07:25 AM:

1/31/97 - 8:07:25 AM: START OF LLCECALC

1/31/97 - 8:07:26 AM:

1/31/97 - 8:07:27 AM: LLCE Data File Selected: c:llecedataltestedf

1/31/97 - 8:07:27 AM: Gamma Assay File Selected: c:llicecalclaz13kav2

1/31/97 - 8:07:27 AM:

1/31/97 - 8:07:38 AM: START - Analysis of Gamma Assay Fite

1/31/97 - 8:07:39 AM:

1/31/97 - 8:07:39 AM: Reading Gamma Assay Data File: az]3a.av2

1/31/97 - 8:07:55 AM: Gamma File: az1 3a.av2 was successfully sead

1/31/97 - 8:07:56 AM: 664 data records were read into Table 'RAWDATA'.

1/31/97 - 8:07:56 AM:

1/31/97 - 8:08:07 AM: Copying RAWDATA to Table GAMMADATA

1/31/97 - 8:08:08 AM:

1/31/97 - 8:08:08 AM: Converting Activity from Microcuries to Curies.

1/3197 - 8:08:09 AM: Make Sure That Position Measurements are Positive.

1/31/97 - 8:08:09 AM: Max Position = 5.9004c+4 feet

1/31/97-8:08:10 AM: Since this position > 1000 it is assummed that measurements are in thousands of a feet

1/31/97 - 8:08:10 AM: Correcting Database to position in feet.

1/31/97 - 8:08:Il AM: Max Position (now): 5.9004e+1 feet

1/31/97 - 8:08:11 AM:

1/31/97 - 8:08:19 AM: START - Checking for Zero and Inconsistant Rosition Records.

1/31/97 - 8:08:29 AM: Record: 1712560 Positions Not Uniform. Max: 4.9428c+1 Min: 4.8489e+1 Avg:4.9139e+1 Set all to Min value: $4.8489 \mathrm{et} 1$

1/31/97 - 8:08:30 AM: Record: 1712580 Positions Not Uniform. Max: 5.0908e+1 Min: 5.0579e+1 Avg: 5.0661 e+l Set all to Min value: $5.0579 e+1$ 1/31/97 - 8:08:31 AM: Record: 1713000 Positions Not Uniform. Max: 5.0714e+1 Min: 5.0287e+1 Avg: 5.0588etl Set all to Min value: 5.0287e+1 1/31/97 - 8:08:33 AM: Record: 1713030 Positions Not Uniform. Max: 5.1583e+1 Min: 5.1024e+1 Avg: 5.121c+1 Set all to Min value: 5.1024c+1 1/31/97 - 8:08:34 AM: Record: 1713040 Positions Not Uniform. Max: 5.2802e+1 Min: 5.2195e+1 Avg: 5.2382e+1 Set all to Min value: S.2195e+1 1/31/97 - 8:08:34 AM: Record: 1713050 Positions Not Uniform. Max: 5.402te+1 Min: 5.3351e+1 Avg: 5.3495e+1 Set all to Min value: 5.335le+1 1/31/97 - 8:08:35 AM: Record: 1713070 Positions Not Uniform. Max: 5.3428e+1 Min: 5.2995e+I Avg: 5.3103e+1 Set all to Min value: 5.2995e+1 1/31/97 - 8:08:36 AM: Record: 1713080 Positions Not Uniform. Max: 5225e+1 Min: 5.187e+1 Avg: 5.1933et1 Set all to Min value: 5.187e+1 1/31/97 - 8:08:37 AM: Record: 1713090 Positions Not Uniform. Max: 5.241 le+1 Min: 5.2078c+1 Avg: 5.2363e+1 Set all to Min value: 5.2078e+1 1/31/97 - 8:08:38 AM: Record: 1713100 Positions Not Uniform. Max: 5.3579e+1 Min: 5.3246e+1. Avg: 5.3528e+l Set all to Min value: 5.3246e+1 1/31/97 - 8:08:39 AM: Record: 1713110 Positions Not Uniform: Max: 5.475le+1 Min: 5.4473e+1 Avg: 5.473le+1 Set all to Min value: 5.4473e+1 1/31/97 - 8:08:39 AM: Record: 1713120 Positions Not Uniform. Max: 5.5909e+1 Min: 5.5688e+1 Avg: 5.5771e+1 Set all to Min valve: S.5688e+1 1/31/97 - 8:08:40 AM: Record: 1713150 Positions Not Uniform. Max: 5.6652e+1 Min: 5.66e+1 Avg: 5.6609e+1 Set all to Min value: 5.66e+1 1/31/97 - 8:08:41 AM: Record: 1713160 Positions Not Uniform. Max: 5.5458e+1 Min: 5.5407e+1 Avg. 5.541e+1 Set all to Min value: 5.5407e+1 1/31/97 - 8:08:42 AM: Record: 1713180 Positions Not Unifom. Max: $5.6516 e+1$ Mis: 5.6459e+1 Avg: 5.6508e+1 Set all to Min value: $5.6459 e+1$ 1/31/97 - 8:08:43 AM: Record: 1713190 Positions Not Uniform. Max: 5.7739e+1 Min: 5.7684e+1 Avg: 5.7728e+1 Set all to Min value: $5.7684 e+1$ 1/31/97 - 8:08:44 AM: Record: 1713210 Positions Not Uniform. Max: 5.78e+1 Min: 5.7745e+1 Avg: 5.7749e+1 Set all to Min value: 5.7745e+1 1/31/97 - 8:08:45 AM: Record: 1713220 Positions Not Unifomm. Max: 5.6613e+1 Min: 5.656e+1 Avg: 5.6572e+1 Set all to Min value: 5.656e+1 1/31/97 - 8:08:46 AM: Record: 1713230 Positions Not Uniform. Max: $5.6821 \mathrm{t}+1$ Min: 5.6765e+1 Avg: 5.6805e+1 Set all to Min value: $5.6765 e+1$ 1/31/97 - 8:08:47 AM: Record ID 17] 1230 reads Zero Position. Prev:1.4046e+1 Next: I.4046e+l Position Corrected to : I.4046e+1 1/31/97 - 8:08:48 AM: END - Position Check Complete.

1/31/97 - 8:08:48 AM: 
1/31/97 - 8:08:49 AM: START - Get Gamma Assay Record Start Poins 1/31/97 - 8:08:53 AM: Min Travel for this LLCE is $9.21 \mathrm{e}-1 \mathrm{ft}$, Max: 1.27et+0 ft, Avg: $1.2001 \mathrm{et}+0 \mathrm{ft}$ 1/31/97 - 8:08:54 AM: Deleting Record 1711200 since L.LCE is not moving 1/31/97 - 8:08:55 AM: Deleted Record 171 1200 from table GammaData 1/31/97 - 8:08:55 AM: Deletod Record 171 1200 from table Positions 1/31/97 - 8:08:56 AM: Deleting Record 1711210 since LLCE is not moving 1/31/97 - 8:08:56 AM: Deleted Record 1711210 from table GamunaData 1/31/97 - 8:08:57 AM: Deleted Record 1711210 from table Positions 1/31/97 - 8:08:58 AM: Deleting Record 1711220 since LLCE is not moving 1/31997-8;08:58 AM: Deleted Record 1711220 from table GammaData 1/31/97 - 8:08:59 AM: Deleted Record 1711220 from table Positions 1/31/97 - 8:08:59 AM: Deleting Record 1711230 since LLCE is not moving 1/31/97 - 8:09:00 AM: Deleted Record 1711230 from table GammaData 1/3 1/97 - 8:09:01 AM: Deleted Record 1711230 from table Positions 1/31/97 - 8:09:01 AM: Deleting Record 1711240 since LLCE is not moving 1/31/97 - 8:09:02 AM: Deleted Record 1711240 from table GammaDats 1/31/97 - 8:09:03 AM: Deleted Record 171 1240 from table Positions 1/31/97 - 8:09:03 AM: Deleting Record 1711250 since $L U C E$ is not moving 1/31/97 - 8:09:04 AM: Deleted Record 1711250 from table GammaData 1/31/97 - 8:09:04 AM: Deleted Record 1711250 from table Positions 1/31/97 - 8:09:05 AM: Deleting Record 1711280 since LLCE is not moving 1/31/97 - 8:09:06 AM: Deleted Record 1711280 from table GammaData 1/31/97 - 8:09:06 AM: Deleted Record 1711280 from table Positions 1/31/97 - 8:09:07 AM: Deleting Record 1711290 since LLCE is not moving 1/31/97 - 8:09:07 AM: Deleted Record 1711290 from table GammaData 1/31/97 - 8:09:08 AM: Deleted Record 1711290 from table Positions 1/31/97 - 8:09:09 AM: Deleting Record 1711300 since LLCE is not moving 1/3197 - 8:09:09 AM: Deleted Record 1711300 from table GammaDrta 1/31/97 - 8:09:10 AM: Deleted Record 1711300 from table Positions 1/31/97 - 8:09:10 AM: Deleting Record 1711310 since LLCE is not moving 1/31/97 - 8:09:11 AM: Deleted Record 1711310 from table GammaDat 1/31/97 - 8:09:12 AM: Deleted Record 1711310 from table Positions 1/31/97 - 8:09:12 AM: Deleting Record 1711320 since LLCE is not moving 1/31/97 - 8:09:13 AM: Deleted Record 1711320 from table GammaData 1/31/97 - 8:09:13 AM: Deieted Record 1711320 from table Positions 1/31/97 - 8:09:14 AM: Deleting Record 1711340 since LLCE is not moving 1/31/97 - 8:09:15 AM: Deleted Record 1711340 from tsble GermmaData 1/31/97 - 8:09:15 AM: Deleted Record I711340 from table Positions 1/31/97 - 8:09:16 AM: Deleting Record 171 1350 since LLCE is not moving 1/31/97 - 8:09:16 AM: Deleted Record 1711350 from table GammaData 1/31/97 - 8:09:17 AM: Deleted Record 1711350 from table Positions 1/3197 - 8:09:18 AM: Deleting Record 1711370 since LLCE is not moving 1/31/97 - 8:09:18 AM: Deleted Record 1711370 from table GammaDats 1/31/97 - 8:09:19 AM: Deleted Record 1711370 from table Positions 1/3197 - 8:09:19 AM: Deleting Record 1711380 since LLCE is not moving 1/31/97 - 8:09:20 AM: Deleted Recond 1711380 from table GammaData 1/31/97 - 8:09:21 AM: Deleted Record 1711380 from table Positions 1/31/97 - 8:09:21 AM: END - Find Detector Start Points $1 / 31 / 97$ 8:09:22 AM:

1/31/97 - 8:09:22 AM: START - Checking for Superceeded Records (Backward motion of LLCE) 1/31/97 - 8:09:23 AM: Deleting Superceeded Record 1713220

1/31/97 - 8:09:24 AM: Deleted Record 1713220 from table GammaData 1/31/97 - 8:09:24 AM: Deleted Record 1713220 from table Positions 1/31/97 - 8:09:25 AM: Deleting Superceeded Record 1713210

1/31/97 - 8:09:26 AM: Deleted Record 1713210 from table GammaData 1/31/97 - 8:09:26 AM: Deleted Record 1713210 from table Positions 1/31/97 - 8:09:27 AM: Deleting Supesceeded Record 1713200 1/31/97 - 8:09:28 AM: Deleted Record 1713200 from table GarnmaDats 1/31/97 - 8:09:28 AM: Deleted Record 1713200 from table Positions 1/3197 - 8:09:29 AM: Recosd 1713220 is inserted : 1/31/97 - 8:09:29 AM: In middle of Record 1713190

1/31/97 * 8:09:30 AM: Recond 1713190 new end position is now 5.656e+1 Aetivities have been reduced by $91.755 \%$ 1/31/97 - 8:09:31 AM: Deleting Superceeded Record 1713160 1/31/97 - 8:09:31 AM: Deleted Recoid 1713160 from table GammaData 1/31/97 - 8:09:32 AM: Deleted Record 1713160 from table Positions 1/31/97 - 8:09:33 AM: Deleting Superceeded Record 1713150 1/31/97 - 8:09:33 AM: Deleted Record 1713150 from table GammaDsra 1/31/97 - 8:09:34 AM: Deleted Record 1713150 from table Positions 1/31/97 - 8:09:34 AM: Deleting Superceeded Record 1713140 1/31/97 - 8:09:35 AM: Deleted Record 1713140 from table GammaData 1/31/97 - 8:09:36 AM: Deleted Record 1713140 from table Positions 
1/31/97 - 8:09:36 AM: Deleting Superceeded Record 1713130 1/31/97 - 8:09:37 AM: Deleted Record 1713130 from tabje GammaData 1/3197 - 8:09:38 AM: Deleted Record 1713130 from table Positions 1/31/97 - 8:09:38 AM: Record 1713160 is inserted : 1/31/97 - 8:09:39 AM: In middte of Record 1713120 1/31/97 - 8:09:39 AM: Record 1713120 new end position is now 5.5407e+1 Activities have been rechuced by $23.128 \%$ 1/31/97 - 8:09:40 AM: Deleting Superceeded Record 1713080 1/31/97 - 8:09:41 AM: Deleted Record 1713080 from table GammaData 1/31/97 - 8:09:41 AM: Deleted Record 1713080 from table Positions 1/31/97 - 8:09:42 AM: Deleting Superceeded Record 1713070 1/31/97 - 8:09:43 AM: Deleted Record 1713070 from table GammaData 1/31/97 - 8:09:44 AM: Deleted Record 1713070 from table Positions 1/31/97 - 8:09:44 AM: Deleting Superceeded Record 1713060 1/31/97 - 8:09:45 AM: Delered Record 1713060 from table GammaData 1/31/97 - 8:09:45 AM: Deleted Record 1713060 from table Positions 1/31/97 - 8:09:46 AM: Deleting Superceeded Record 1713050 1/3197 - 8:09:47 AM: Deleted Record 1713050 from table GammaData 1/31/97 - 8:09:47 AM: Deloted Record 1713050 from table Positions 1/31/97 - 8:09:48 AM: Record 1713080 is inserted : 1/31/97 - 8:09:49 AM: In middle of Record 1713040

1/31/97 - 8:09:49 AM: Record 1713040 new end position is now 5.187e+1 Activities have been reduced by $27.754 \%$ 1/31/97 - 8:09:50 AM: Deleting Superceeded Recard 1713010

1/31/97 - 8:09:50 AM: Deleted Record 1713010 from table GammaData

1/31/97 - 8:09:51 AM: Deleted Record 1713010 from table Positions 1/31/97 - 8:09:52 AM: Deleting Superceeded Record 1713000

1/31/97 - 8:09:52 AM: Deleted Record 1713000 from table GammaData 1/31/97 - 8:09:53 AM: Deleted Record 1713000 from table Positions 1/31/97 - 8:09:54 AM: Deleting Superceeded Record 1712590

1/31/97 - 8:09:54 AM: Deleted Record 1712590 from table GammaData 1/31/97 - 8:09:55 AM: Deleted Record 1712590 from table Positions 1/31/97 - 8:09:55 AM: Deleting Superceeded Record 1712580 1/31/97 - 8:09:56 AM: Deleted Record 1712580 from table GammaData 1/31/97 - 8:09:57 AM: Deleted Record 1712580 from table Positions 1/31/97 - 8:09:57 AM: Record 1713010 is inserted : 1/31/97 - 8:09:58 AM: In middle of Record 1712570

1/31/97 - 8:09:59 AM: Record 1712570 new end position is now 4.9244e+1 Activities have been reduced by 38.013\% 1/31/97 - 8:09:59 AM: Deleting Superceeded Record 1712470

1/31/97 - 8:10:00 AM: Deleted Record 1712470 from table GammaData

1/31/97 - 8:10:01 AM: Deleted Record 1712470 from table Positions

1/31/97-8:10:01 AM: Record 1712470 is inserted:

1/31/97 - 8:10:02 AM: In middle of Record 1712360

1/31/97 - 8:10:02 AM: Record 1712360 new end position is now 4.3981 e+1 Activities have been reduced by $4.083 \%$

1/31/97 - 8:10:03 AM: Deleting Superceeded Record 1712330

1/31/97 - 8:10:04 AM: Deleted Record 1712330 from table GammaData

1/31/97 - 8:10:04 AM: Deleted Record 1712330 from table Positions

1/31/97 - 8:10:05 AM: Deieting Superceeded Record 1712310

1/31/97 - 8:10:06 AM: Deleted Record 1712310 from table GammaData

1/31/97 - 8:10:06 AM: Deleted Record 1712310 from table Positions

1/31/97 - 8:10:07 AM: Deleting Superceeded Record 1712300

1/31/97 - 8:10:08 AM: Deleted Record 1712300 from table GammaData

1/31/97 - 8:10:08 AM: Deleted Record 1712300 from table Positions

1/31/97 - 8:10:09 AM: Deleting Superceeded Record 1712290

1/31/97 - 8:10:10 AM: Deleted Record 1712290 from table GammaData 1/31/97 - 8:10:10 AM: Deleted Record 1712290 from table Positions 1/31/97 - 8:10:11 AM: Deleting Superceeded Record 1712260

1/31/97 - 8:10:12 AM: Deleted Record 1712260 from table Gammabata 1/31/97 - 8:10:12 AM: Deleted Record 1712260 from table Postions 1/31/97 - 8:10:13 AM: Deleting Superceeded Recosd 1712230

1/31/97 - 8:10:13 AM: Deleted Record 1712230 from table GammaData 1/31/97 - 8:10:14 AM: Deleted Record 1712230 from table Positions 1/31/97 - 8:10:15 AM: Deleting Superceeded Record 1712220

1/31/97 - 8:10:15 AM: Deleted Record 17i2220 from table GammaData 1/31/97 - 8:10:16 AM: Deleted Record 1712220 from table Positions 1/31/97 - 8:10:17 AM: Deleting Superceeded Record 1712200 1/31/97 - 8:10:17 AM: Deleted Record 1712200 from table GammaData 1/31/97 - 8:10:18 AM: Deleted Record 1712200 from table Positions 1/31/97 - 8:10:19 AM: Deleting Supercecded Record 1712120 1/31/97 - 8:10:19 AM: Deleted Record 1712120 from table GemmaData 1/31/97 - 8:10:20 AM: Deleted Record 1712120 from table Positions 1/31/97 - 8:10:21 AM: Record 1712120 is inserted:

1/31/97 - 8:10:21 AM: In middie of Record 1712100 
1/31/97 - 8:10:22 AM: Record 1712100 new end position is now 3.9791e+1 Aetivities have been reduced by $8.666 \%$

1/31/97 - 8:10:23 AM: Deleting Superceeded Recond 17!1580

1/31/97 - 8:10:23 AM: Deleted Record 1711580 from table GanmaData

1/31/97 - 8:10:24 AM: Deleted Record 17:11580 from table Positions

1/31/97 - 8:10:25 AM: Deleting Superceeded Record 1711560

1/31/97 - 8:10:25 AM: Deleted Record 1711560 from table GammaData

1/31/97 - 8:10:26 AM: Deleted Record 1711560 from table Positions

1/31/97 - 8:10:26 AM: Recond 1711580 ts inserted:

1/31/97 - 8:10:27 AM: In midate of Record 171 1520

1/31/97 - 8:10:28 AM: Record 1711520 new end position is now 2.9095 e+l Activities have been teduced by $85.658 \%$

1/31/97 - 8:10:28 AM; END - Check for Superceeded Records is Complete.

1/31/97 - 8:10:29 AM:

1/31/97 - 8:10:30 AM: START - Applying Geometry Correction Factors

1/31/97 - 8:10:3t AM: Found Min Position: 6.2409e+0 ft, Max Diraension: 5.9004e+1 fo, Distance Measured: $5.2763 \mathrm{e}+1 \mathrm{ft}$

1/31/97 - 8:1 1:07 AM: The Bottom Tip of the LLCE Cooresponds to the End Crane Reading

1/31/97 - 8:11:08 AM: Changing Postion Measurements so Zero (0) position represents tip of LLCE

1/31/97 - 8:11:10 AM: Removing Record ID 1711120 because it's position is above mounting flange of LLCE

1/31/97 - 8:11:10 AM: Removing Record 1D 1711150 because it's position is above mounting flange of LLCE

1/31/97 - 8:11:11 AM: Removing Record ID 1711160 because it's position is above mounting flange of LLCE

1/31/97 - 8:11:12 AM: Geometry Correction Factors at end location 1.4929e+1 meters: Geom Corl: 1, Geom Cor2: 1, Geom Cor3: 1

t/31/97 - 8:11:12 AM: Comecting 137CS, Record 1711 L60, for Detector \#1 Was: 2.121e-4 Now: 2.12le-4 curies

1/31/97 - 8:11:13 AM: Correcting 137CS, Record 1711170, for Detector \#1 Was: 5.794e-5 Now: 5.794e.5 curies

1/31/97 - 8:11:13 AM: Correcting 137CS, Record 1711180, for Detector \#1 Was: $1.376 e-4$ Now: $1.376 e-4$ cusies

1/31/97 - 8:1 1:14 AM: Correcting 137CS, Record 1711190, for Detector $\$ 11$ Was: 1.476e-4 Now: 1.476e-4 curies

1/31/97 - 8:11:15 AM: Correcting 137CS, Record 1711390, for Detector \#1 Was: 2.186e-4 Now: $2.186 \mathrm{e}-4$ curies

1/31/97 - 8:11:15 AM: Correcting 137CS, Record 1711400, for Detector \#1 Was: 1.873e-4 Now: 1.873e-4 curies

1/31/97 - 8:11:16 AM: Correcting 137CS, Record 1711410, for Detector \#1 Was: 2.181e-4 Now: 2.181e-4 curies

1/31/97 - 8:11:16 AM: Correcting 137CS, Record 1711420, for Detector $\# 1$ Was: 9.601e-5 Now: 9.601e-5 curies

1/31/97 - 8:11:17 AM: Correcting 137CS, Record 1711430, for Detector $\$ 1$ Was: 8.66e-5 Now: 8.66e-5 curies

1/31/97 - 8:11:18 AM: Correcting 137CS, Record 171 1440, for Detector $\# 1$ Was: 2.037e-4 Now: $2.037 \mathrm{e}-4$ curies

1/31/97 -8:11:18 AM: Correcting 137CS, Record 1711450, for Detector \$1 Was: 7.78e-4 Now: 7.78c-4 curies

1/31/97 - 8:11:19 AM: Conecting 137CS, Record 1711460, for Detector \$1 Was: 1.368e-3 Now: 1.368e-3 auries

1/3197 - 8:11:19 AM: Correcting 137CS, Record 1711480, for Detector \#1 Was: 3.164e-3 Now: 3.164e-3 curies

1/31/97 - 8:11:20 AM: Correcting 137CS, Record 1711520, for Detector $\$ 1$ Was: 3.8781e-4 Now: 3.8781e-4 curies

1/31/97 - 8:11:20 AM: Correcting 137CS, Record 1712040, for Detector $\# 1$ Was: 8.545e-4 Now: 8.545e-4 curies

1/31/97 - 8:11:21 AM: Correcting 137CS, Record 1712100, for Detector \#1 Was: 1.454e-3 Now: 1.454e-3 curries

1/31/97 - 8:11:22 AM: Correcting 137CS, Record 1712160, for Detector \#t Was: 1.908e-3 Now: 1.908e-3 curies

1/31/97 - 8:11:22 AM: Correcting 137CS, Record 1712360, for Detector H1 Was: 1.0484e-3 Now: 1.0484e-3 curies

1/31/97 - 8:11:23 AM: Conrecting 137CS, Record 1712490, for Detector 111 Was: 1.225e-3 Now: 1.225e-3 curies 1/31/97 - 8:11:23 AM: Correcting 137CS, Record 1712540, for Detector Al Was: 1.169e-3 Now: 1.169e-3 curies 1/31/97 - 8:11.24 AM: Corecting 137CS, Record 1712560, for Detector \#1 Was; 1.043e-3 Now: 1.043e-3 curics 1/31/97 - 8:11:25 AM: Conrecting 137CS, Record 1713020, for Detector HI Was: 7.373e-4 Now: 7.373e-4 curies 1/31/97 - 8:11:25 AM: Correcting 137CS, Record 1713030, for Detector 11 Was: 1.966e-4 Now: 1.966e-4 curies 1/31/97 - 8: [1:26 AM: Correcting 137CS, Record 1713040, for Detector $\$ 1$ Was: 5.5998e-4 Now: 5.5998c-4 curies 1/31/97 - 8:11:26 AM: Correcting 137Cs, Record 1713090, for Detector \#1 Was: $7.351 \mathrm{e}-4$ Now: 7.351 le-4 curies 1/31/97 - 8:11:27 AM: Correcting 137CS, Record 1713100, for Detector \#1 Was: 8.393e-4 Now: 8.393e-4 curies 1/31/97 -8:11:28 AM: Correcting 137CS, Record 1713110, for Detector \#1 Was: 8.241e-4 Now: $8.241 \mathrm{c}-4$ curies 1/31/97 - 8:11:28 AM: Correcting 137CS, Record 1713120, for Detector 11 Was: 7.2744e-4 Now: 7.2744e-4 auries 1/31/97 - 8:11:29 AM: Correcting 137CS, Recotd 1713180, for Detector \#1 Was: 9.313e-4 Now: 9.313e-4 curies 1/31/97 - 8:11:29 AM: Correcting 137CS, Record 1713190, for Detector \#1 Was: 1.6679e-4 Now: 1.6679e-4 euties 1/31/97 - 8:11:30 AM: Correcting 137CS, Record 1713230, for Detector \#1 Was: 1.03e-3 Now: 1.03e-3 curies 1/31/97 - 8:11:31 AM: Correcting 137CS, Record 1713250, for Detector \#1 Was: 9.324e-4 Now: 9.324e-4 curies 1/31/97 - 8:11:31 AM: Correcting 137CS, Record 1713030, for Detector \#3 Was: 4.543e-11 Now: 4.543e-11 cuties 1/31/97 - 8:11:32 AM: Correcting 137CS. Record 1713090, for Detector \#3 Was: 2.419e-11 Now: 2.419e-11 curies 131/97 - 8:11:32 AM: Correcting 137CS, Record 1713120, for Detector \#3 Was: 1.5682e-I 1 Now: 1.5682c-I I curies 1/3197 - 8:1 1:33 AM: Correcting 137CS, Record 1713190, for Detector \#3 Was: 4.8958c-12 Now: $4.8958 c-12$ curies 1/31\%9 -8:11:34 AM: Correcting 137CS, Reeord 1713230, for Detector 13 Was: 3.165e-11 Now: 3.j65e-11 curies 1/31/97 - 8:11:34 AM: Corrceting 137CS, Record 1713240, for Detector \#3 Was: 5.908e-11 Now: 5.908e-11 curies 1/B1/97 - 8:11:35 AM: Correcting 137CS, Record 1713250, for Detector \#3 Was: 4.94e-11 Now: 4,94e-11 curies 1/31/97 - 8:11:35 AM: END - Applying Geometry Correction Factors

1/31/97 - 8:11:36 AM:

1/31/97 - 8:11:37 AM: START - Check for detector Correction factors for 137Cs

1/31/97 - 8:1 1:37 AM: Read from file C:LLCECALCUlcecalc.Ini Cor $1=1$ Cor2 $=1.165 \operatorname{Cor} 3=24790000$

1/31/97 - 8:11:38 AM: START - Estimate Detector Correction Factors

1/31/97 - 8:1 1:39 AM: Detector I readings Found

1/31/97 - 8:11:39 AM: Detector 2 readings Not Found

1/31/97 - 8:11:40 AM: Detector 3 readings Found

1/3197 - 8:11:40 AM: Detector 3 Shielding Correation Fretor estimated to be $2.7765 \mathrm{et} 7$

1/31/97 - 8:11:41 AM: END + Estimate Detector Correction Factors

1/31/97 - 8:11:41 AM: Shielding Calibration Correction Factor will be 1 For Detector \#1

1/3197 - 8:11:42 AM: Shielding Calibration Correction Factor will be 1.165 For Detector $\$ 2$ 
1/31/97 - 8:11:43 AM: Shielding Calibration Correction Factor will be 27765004.9911328 For Detectot $\# 3$ 1/31/97 + 8:11:44 AM: Correcting 137Cs for Detector \$3, Record D: 1713030, Was: 4.543e-11 Now: 1.2614e-3 1/31/97 - 8:11:44 AM: Comecting 137Cs for Detector \#3, Record ID: 1713090, Was: 2.419e-11 Now: 6.7164e-4 1/31/97 - 8:11:45 AM: Correcting 137Cs for Detector \#3, Record ID: 1713120. Was: 1.5682e-11 Now: 4.354le-4 1/31/97 - 8:11:45 AM: Correcting 137Cs for Detecter \#3, Record ID: 1713190, Was: 4.8958e-12 Now: 1.3593e-4 1/31/97 - 8:11:46 AM: Correcting 137Cs for Detector \#3, Record ID: 1713230, Was: 3.165e-11 Now: 8.7876e-4 1/31/97 - 8:11:47 AM: Correcting 137Cs for Detector 43, Record 1D: 1713240, Was: 5.908e-11 Now: 1.6404e-3 1/31/97 - 8:11:47 AM: Correcting 137Cs for Detector \#3, Record ID: 1713250, Was: 4.94e-11 Now: 1.3716e-3 1/31/97 - 8:1 1:48 AM: END - Detector Correction factors Complete

I/31:97 - 8:11:48 AM:

1/31/97 - 8:11:49 AM: START - Looking For Missing Cs-137 Gamma Data (Gaps in Gamma Measurements)

1/31/97 - 8:11:58 AM: Gap Found, Creating new Record: 1712493 Start: 1.20 let1 End: 1.3766e+1 1/3197 - 8:11:58 AM: Gap Found, Creating new Record: 1712163 Start: 1.6174e+1 End: 1.826e+1 1/31/97 - 8:11:59 AM: Gap Found, Creating new Record: 1712043 Start: 2.0309e+1 End: $2.2215 \mathrm{e}+1$ 1/31/97 - 8:11:59 AM: Gap Found, Creating new Record: 1711523 Start: $2.3415 e+1$ End: $2.9909 e+1$ 1/31/97 - 8:12:00 AM: Gap Found, Creating new Recond: 1711483 Start: 3.0081e+1 End: 3.2717e+1 1/31/97 - 8:12:01 AM: Gap Found, Creating new Record: 1711463 Start: 3.3917e+1 End: 3.5237e+1 1/31/97 - 8:12:01 AM: Gap found at Rocord 1712570 Start: 9.76e+0 End: 1.0515e+1 1/31/97 - 8:12:02 AM: Gap found at Record 1712493 Start 1.201e+1 End: 1.3766e+1 1/31/97 - 8:12:03 AM: Gap found at Record 1712163 Start: 1.6174c+1 End: 1.826e+1 1/31/97 - 8:12:03 AM: Gap found at Record 1712043 Stert: 2.0309e+1 End: 2.2215e+1 1/31/97 - 8:12:04 AM: Gap found at Record 1711523 Start: 2.3415e+1 End: $2.9909 \mathrm{et}+1$ 1/31/97 - 8:12:04 AM: Gap found at Recond 1711483 Start: 3.008le+1 End: 3.2717e+1 1/3197 - 8:12:05 AM: Gap found at Record 1711463 Start: 3.3917e+1 End: 3.5237e+1 1/31/97 - 8:12:05 AM: Gap found at Record 1711169 Start 4.8658e+1 End: $4.8979 \mathrm{et}$ I

1/31/97 - 8:12:35 AM: User Chose to have the program estimate the content of Record; 1712570 1/3197 - 8:12:35 AM: Deleted Record 1712570 from table GammaData

1/31/97 - 8:12:36 AM: Deleted Record 1712570 from table Positions

1/31/97 - 8:12:37 AM: New Record 1713019 Created by prograrn for Gap 1712570 Start: 9.76e+p End: 1.0515e+1 Activity (ci/ft): 2.5164e-3 1/31/97 - 8:12:38 AM: User Chose to have the program estimate the content of Record: 1712493

1/31/97 - 8:12:39 AM: Waming - Record ID: 1712493 Was Not Found in Table GammaData. Delete Record Failed

1/31/97 - 8:12:40 AM: Deleted Record 1712493 from table Positions

1/31/97-8:12:40 AM: New Record 1712539 Created by program for Gap 1712493 Start: 1.201et1 End: 1.2888et 1 Activity (ci/ft):9.7423e-4

1/31/97-8:12:41 AM: New Record 1712538 Crated by program for,Gap 1712493 Start: $1.2888 \mathrm{et} 1$ End: $1.3766 \mathrm{et} 1$ Activity (ci/ft): $9.7437 \mathrm{c}-4$. 1/31/97 - 8:12:44 AM: User Chose to have the progrem estimate the content of Record: 1712163

1/31/97 - 8:12:45 AM: Waming - Record tD: 1712163 Was Not Found in Table GammaData Delete Record Failed 1/31/97 - 8:12:46 AM: Deleted Record 1712163 from table Positions

1/31/97 - 8:12:46 AM: New Record 1712359 Created by program for Gap 1712163 Start: 1.6174e+1 End: 1.7217c+1 Activity (ci/t): 1.2923e-3 131/97 - 8:12:47 AM: New Record 1712358 Created by program for Gap 1712163 Start: 1.7217e+1 End: 1.826e+1 Activity (ci/ft): $1.655 e-3$ 1/31/97 - 8:12:56 AM: Uset Chose to have the program estimate the content of Record: 1712043

I/31/97 - 8:12:56 AM: Waming - Record ID: 1712043 Was Not Found in Table GanmaData. Delete Record Failed 1/31/97 - 8:12:57 AM: Deleted Record 1712043 from table Positions

1/31/97 - 8:12:58 AM: New Recosd 1712099 Created by progran for Gep 1712043 Start: 2.0309e+1 End: 2.1262e+1 Activity (ci/ft): J.1204t-3 1/31/97 - 8:12:58 AM: New Record 1712098 Created by program for Gep 1712043 Start: 2.1262e+1 End: 2221 et+1 Activity (ci/f): $9.2863 e-4$ 1/31/97 - 8:13:00 AM: User Chose to have the program estimate the content of Record: 1711523

1/31/97 - 8:13:01 AM: Warning - Record ID: 1711523 Was Not Found in Table GammaData. Delete Record Failed 1/31/97 - 8:13:01 AM: Deieted Record 1711523 from table Positions

1/31/97 - 8:13:02 AM: New Record 1712039 Created by program for Gap 1711523 Start: $2.3415 e+1$ End: $2.4497 e+1$ Activity (ci/ft): 9.5696e-4 1/31/97 - 8:13:03 AM: New Record 1712038 Created by program for Gap 1711523 Start: 2.4497e+1 End: 2.558e+1 Activity (ei/t): $1.1893 \mathrm{e}-3$ 1/31/97 - 8:13:03 AM: New Record 1712037 Created by program for Gap 1711523 Start: 2.558e+1 End: 2.6662e+1 Activity (ci/ft): 1.4216e-3 1/31/97 - 8:13:04 AM: New Record 1712036 Created by program for Gap 1711523 Start: 2.6662e+1 End: 2.7744e+1 Activity (cleft): $1.6539 e-3$ 1/31/97 - 8:13:05 AM: New Record 1712035 Created by program for Gap 171 1523 Start: 2.7744c+1 End: 2.8827e+1 Activity (ci/f): $1.8862 e-3$ 1/31/97 - 8:13:05 AM: New Record 1712034 Created by program for Gap 1711523 Start: 2.8827e+l End: 2.9909e+1 Activity (ci/ft): 2.1185e-3 1/31/97 - 8:13:07 AM: User Chose to have the program estimate the content of Record: 17] [483

1/31/97 - 8:13:08 AM: Waming - Record ID: 1711483 Was Not Found in Table GammaData. Delete Record Falled

1/31/97 - 8:13:08 AM: Deleted Record 1711483 from table Posittons

1/31/97 - 8:13:09 AM: New Record 1711519 Created by program for Gap 171 1483 Start: 3.0081e+1 End: $3.096 e+1$ Activity (ci/ft): 2.3137e-3 1/31/97 - 8:13:10 AM: New Record 1711518 Created by prógram for Gap 1711483 Start: 3.096e+1 End: 3.1838e+1 Activity (ci/A): 2.41S1e-3 1/31/97-8:13:10 AM: New Record 1711517 Created by program for Gap 1711483 Start: 3.1838e+1 End: $3.2717 e+1$ Activity (ci/ft): $2.5165 e-3$ 1/31/97 - 8:13:16 AM: User Chose to haye the program estimate the content of Record: 1711463

1/31/97 - 8:13:17 AM: Werning - Record ID: 1711463 Was Not Found in Table GammsData. Delete Record Failed

1/31/97 - 8:13:18 AM: Deleted Record 1711463 from table Positlons

1/31/97 - 8:13:18 AM: New Record 1711479 Crtated by program for Gap 171 1463 Start: 3.3917e+1 End: 3.5237e+l Activity (ci/ft): $1.8702 e-3$ 1/31/97 -8:13:20 AM: User Chose to have the program estimate the content of Record: 1711169

131/97 - 8:13:21 AM: Waming - Record ID: 17I1169 Was Not Found in Table GarnmaDaan Delete Record Failed

1/31/97 - 8:13:22 AM: Deleted Recond 1711169 from table Positions

1/31/97 - 8:13:22 AM: New Record 1711169 Created by progrem for Gap 171 1 ] 69 Start: 4.8658e+1 End: 4.8979e+1 Activity (ci/ft): 4.5694e-5

1/31/97 - 8:13:23 AM: END - Looking For Missing Gamma Dals Complete

1/31/97-8:13:24 AM:

1/31/97 - 8:13:25 AM: START - Calculate Cs-137 Curie Content for Tank Weste Layers

1/31/97 - 8:13:26 AM: Layer \#1 Cs-137 Content $=5.3029 e-2 \mathrm{Ci}$. 
131997 - 8:13:27 AM: Cs-137 Content for all tank waste layers $=5.3029 \mathrm{e}-2 \mathrm{Ci}$.

1B197 - 8:13:28 AM: END - Calculate Cs-137 Curio Content for Tank Waste Layers

1B197 - 8:13:28 AM:

1/3197 - 8:14:28 AM: START - Aralysis of LLCE Waste Characterization

1/31/97 - 8:14:29 AM:

1/3197 - 8:14:29 AM: START - Calculate Radiochemical/Chemical Content of LLCE Waste

1/31/97 - 8:14:30 AM: Converting mass units to grams and curies

1/31/97 - 8:14:31 AM: New record gerierated in Tarkchar table for 240PU. Layer Content is 5.883e-9 Ci.

1/31/97 - 8:14:32 AM: Changed Content of 239PU Was: 0.0000000166 Now: 0.000000026617 Ci.

$1 / 31 / 97-8: 14: 33$ AM: Cleared out old cafes (if any)

1/31/97 - 8:14:33 AM: Estimating the Content of each Radiochemical/Chemical in LLCE waste

I/31/97 - 8:14:36 AM: END - Calculate Radiochemical/Chemical Content of LLCE Waste

1/31/97 - 8:14:37 AM:

1/31/97 - 8:14:37 AM: START - Calculate to see if SARP Limits are exceeded.

13197-8:14:39 AM: No SARP Limits have been exceeded.

1/3L97 - 8:14:40 AM: SEP is not required for this waste package

1/31/97 - 8:14:41 AM: END - Calculate to see if SARP Limits are exceeded.

1/31/97 - 8:14:41 AM:

1/31/97 - 8:14:42 AM: START - Calculate for Cat 1 and Cat $3 \mathrm{LLW}$

1/31/97 - 8:14:43 AM: Volume for LLCE weste container: 5 is $2.7028 \mathrm{et} 1 \mathrm{~m}^{\wedge} 3$

1/31/97 - 8:14:45 AM: Cat 1 Sum of fractions is : $3.57360-1$

1/BI/97 - 8:14:46 AM: Car 3 Sum of fractions is : 7.3316e-7

1/31/97 - 8:14:46 AM: NRC Class C Sum of fractions is : 4.2747e-7

1/31/97 - 8:14:47 AM: Cat 3 Noncombustable Limit Sum of fractions is : 1.2015e-7

1/31/97 - 8:14:48 AM: LLCE waste is Category 1, LLMW

1/3 1/97 - 8:14:49 AM: LLCE is sultable for near surface disposal (NRC C Fraction < 1)

1/31/97 - 8:14:50 AM: Additional safety analysis is not required for near surface disposal. (Noncomb Fraction <1)

1/31/97 - 8:14:50 AM: END - Calculate for Cat 1 and Car 3 LLW

1/31/97 - 8:14:5I AM:

I/31/97 - 8:14:52 AM: START - Calculate for TRU

1/31/97 - 8:15:12 AM: LLCE Weight is 2.e+3 kg.

I/3I 97 - 8:15:14 AM: LLCE waste is Low Level Mixed Waste (LLMW) since TRU fraetion <1 (6.1617e-5)

1/3: 97 - 8:15:15 AM: LLCE waste in not Greater than NRC Class C since NRC fraction $<1$ (6.1617e-5)

I/31/97 - 8:15:16 AM: END - Calculate for TRU

131/97 - 8:15:17 AM:

1/31/97 - 8:15:17 AM: START - Calculate PE-Ci for TRU waste

1/31/97 - 8:15:18 AM: Since LLCE waste is not TRU this calculation is not required.

1/31/97 - 8:15:19 AM: END - Calculate PE-Ci for TRU waste

1/3197-8:15:20 AM:

1/31/97 - 8:15:21 AM: START - Calculate Pu-239 FGE for TRU waste

1/31/97 - 8:15:22 AM: Since LLCE waste is not TRU this calculation is not required.

1/31/97 - 8:15:23 AM: END - Calculate PL-239 FGE for TRU waste

1/31/97 - 8:15:23 AM:

1/31/97 - 8:15:24 AM: START - Calculatc Alpha Curie Content for TRU waste

1/31/97 - 8:15:25 AM: Since LLCE waste is not TRU this caleulation is not required.

1/3I/97 - 8:15:26 AM: END - Calculate Alpha Curie Content for TRU waste

1/31/97 - 8:15:26 AM:

1/31/97 - 8:15:27 AM: START - Calcuiate for Accountable Nuclear Material

1/31/97 - 8:15:29 AM: LLCE waste does not contain accountable nuclear material.

1/31/97 - 8:15:29 AM: END - Calculate for Accountable Nuclear Material

$1 / 31 / 97$ - 8:15:30 AM:

1/3197 - 8:15:31 AM: START - Calculate heat generation rate of LLCE waste package

1/31/97 - 8:15:33 AM: Total heat generated by LLCE waste is: 1.6481e-3 watts.

1/31/97 - 8:15:34 AM: Internal Volume of selected Container LLCE-5 $=9.5449 \mathrm{e}+2 \mathrm{fM}^{\wedge}$

131/97 - 8:15:35 AM: Heat Generation rate for this LLCE waste is $1.7267 \mathrm{e}-6$ watts/f $\mathrm{f}^{-3}$

1/31/97 - 8:15:36 AM: Heat Generation rate doesn't exceed 0.1 watts/frn 3

1/31/97 - 8:15:36 AM: END - Calculate heat generation rate of $L C E$ waste package

1/31/97 - 8:15:37 AM:

1/31/97 - 8:15:38 AM: START - Calculate Transportation Category

1/31/97 - 8:15:40 AM: A2 Fraction $S u m=1.7856 \mathrm{e}-2$

1/31/97 - 8:15:4 I AM: EP-0063 Appendlx L A2 Limit Fraction - 23206e-2

1/31/97 - 8:15:41 AM: LLCE Wasto Package is Type A Quantity.

1/31/97 - 8:15:42 AM: DE-Ci Calculation is not required.

1/31/97 - 8:15:43 AM: END-Calculate Transpontation Category

1/31/97 - 8:15:44 AM:

1/31/97 - 8:15:44 AM: START - Calculate DE-Ci

131/97 - 8:15:45 AM: DE-Ci Calculation is not required rccording to transportation category.

1/31/97 - 8:15:46 AM: START - Calculate Hazardous Waste Codes

1/31/97 - 8:15:48 AM: Hazardous waste codes F001-F005 apply to all LLCE.

1/31/97 - 8:15:48 AM: No other Waste codes Apply.

1/31/97 - 8:15:49 AM: END - Calculate Hazardous Waste Codes 
131/97 - 8:15:50 AM:

1/31/97 - 8:23:34 AM:

1/31/97 - 8:23:34 AM: START OF LLCECALC

L/31/97-8:23:35 AM:

1/31/97 - 8:23:35 AM: LLCE Data File Selected: civloedataltest.edf

1/31/97 - 8:23:36 AM: Gamma File Dara Present in LLCE Data File

1/31/97 - 8:23:36 AM:

1/31/97 - 8:25:57 AM:

1/31/97 - 8:25:58 AM: START OF LLCECALC

1/31/97 - 8:25:58 AM:

1/31/97 - 8:25:59 AM: LLCE Data File Selected: c:llcedataltest.edf

1/31/97 - 8:25:59 AM: Gamma File Dats Present in LLCE Data File

1/31/97 - 8:26:00 AM:

1/31/97 - 8:26:37 AM: START - Analysis of LLCE Waste Characterization

1/31/97 - 8:26:38 AM:

1/31/97 - 8:26:39 AM: START - Calculate Radiochemica/Chiemical Content of LLCE Waste

1/31/97 - 8:26:39 AM: Converting mass units to grams and curries

1/31/97 - 8:26:40 AM: Cleared out old cales (if any)

1/31/97 - 8:26:41 AM: Estimating the Content of each Radiochemical/Chemical in LLCE waste

131/97 - 8:26:44 AM: END - Calculate Radiochemical/Chemical Content of LLCE Waste

1/31/97 - 8:26:44 AM:

1/31/97 - 8:26:45 AM: START - Calculate to see if SARP Limits are exceeded.

3/31/97 - 8:26:47 AM: No SARP Limits have been exceeded.

$1 / 31 / 97$ - 8:26:47 AM: SEP is not required for this waste package

1/31/97 - 8:26:48 AM: END - Calculate to see if SARP Limits are exceeded.

1/31/97 - 8:26:48 AM:

1/31/97 - 8:26:49 AM: START - Calculate for Cat I and Cat 3 LLW

1/31/97 - 8:26:50 AM: Yolume for LLCE waste container: 5 is $2.7028 \mathrm{e}+1 \mathrm{~m}^{\wedge} 3$

1/31/97 - 8:26:52 AM: Cat I Sum of fractions is : 3.5736e-1

1/31/97 - 8:26:52 AM: Cat 3 Sum of fractions is : 7.3316e-7

1/31/97 - 8:26:53 AM: NRC Class C Sum of fractions is : 4.2747e-7

1/31/97 - 8:26:54 AM: Cat 3 Noncombustable Limit Sum of fractions is : 1.2015e.7

1/31/97 - 8:26:55 AM: LLCE waste is Category 1, LLMW

1/31/97 - 8:26:55 AM: LLCE is suitabic for near surface disposal (NRC C Fraction < 1)

1/31/97 - 8:26:56 AM: Additional safety analysis is not required for near surface disposal. (NonComb Fraction <1)

1/31/97 - 8:26:57 AM: END - Calculate for Cat 1 and Cat $3 \mathrm{LLW}$

1/31/97 - 8:26:57 AM:

1/31/97 - 8:26:58 AM: START - Calculate for TRU

1/31/97 - 8:27:10 AM: LLCE Weight is $2 . e+3 \mathrm{~kg}$.

I/3197 + 8:27:13 AM: LLCE waste is Low Level Mixed Waste (LLMW) since TRU fraction <1 (6.1617e-5)

1/31/97-8:27:14 AM: LLCE waste in not Greater than NRC Class C since NRC fraction $\leqslant 1$ (6.1617e-5)

1/31/97 - 8:27:14 AM: END - Calculate for TRU

I/31/97 - 8:27:15 AM:

1/31/97 - 8:27:16 AM: START - Calculate PE-Ci for TRU waste

1/31/97 - 8:27:17 AM: Since LLCE waste is not TRU this calculation is not required.

1/31/97 - 8:27:17 AM: END - Calculate PE-Ci for TRU waste

1/31/97 - 8:27:18 AM:

1/31/97 - 8:27:19 AM: START - Calculate Pu-239 FGE for TRU wrste

1/31/97 - 8:27:20 AM: Since LLCE waste is not TRU this calculation is not required.

1/31/97 - 8:27:20 AM: END - Calculate PU-239 FGE for TRU waste

$1 / 31 / 97$ - 8:27:21 AM:

1/31/97 - 8:27:22 AM: START - Calculate Alpha Curic Content for TRU waste

1/31/97 - 8:27:23 AM: Since LLCE waste is not TRU this calculation is not required.

1/31/97 - 8:27:23 AM: END - Calculate Alpha Curie Content for TRU waste

1/31/97 - 8:27:24 AM:

1/31/97 - 8:27:25 AM: START - Calculate for Accountable Nuclear Material

1/31/97 - 8:27:26 AM: LLCE waste does not contsin accountable nuclear material.

1/31/97 - 8:27:27 AM: END - Calculate for Accountable Nuclear Material

$1 / 31 / 97-8: 27: 27$ AM:

1/31/97 - 8:27:28 AM: START - Calculate heat gentration rate of LLCE waste package

1/31/97 - 8:27-30 AM: Total heat generated by LLCE waste is: 1.6481e-3 walts.

1/3]/97 - 8-27:31 AM: Internel Volume of selected Container LLCE-5 $=9.5449 \mathrm{e}+2 \mathrm{ft}^{\wedge} 3$

1/31/97 - 8:27:31 AM: Hear Generation rate for this LLCE waste is $1.7267 e-6$ watts/t^3

1/31/97 - 8:27:32 AM: Heat Generation mate dowsi' exceed 0.1 watts/f^3

1/31/97 - 8:27:33 AM: END - Calculare heat generation rate of LLCE waste package

I/31/97 - 8:27:34 AM:

1/31/97 - 8:27:34 AM: START - Calculate Transportation Category

1/31/97 - 8:27:36 AM: A2 Fraction Sum $=1.7856 \mathrm{e} \cdot 2$

1/31/97 - 8:27:37 AM: EP-0053 Appendix L A2 Limít Fraction = 2.3206e-2

1/3107 - 8:27:38 AM: LLCE Waste Package is Type A Quantity.

1/31/97-8:27:38 AM: DE-Ci Calculation is not required. 
1/31/97 - 8:27:39 AM: END-Calculate Transportation Cetegory

I/B197 - 8:27:40 AM:

1/31/97 - 8:27:41 AM: START - Calculate DE-Ci

1/31/97 - 8:27:42 AM: DE-Ci Calculation is not required according to transportation category.

1/31/97 - 8:27:43 AM: START - Calculate Hazardous Waste Codes

1/31/97 - 8:27:43 AM: Hazardous waste codes F001-F005 apply to all LLCE.

1/31/97 - 8:27:44 AM: No other Waste codes Apply.

1/31/97 - 8:27:45 AM: END - Calculate Hazsrơous Waste Codes

1/31/97 - 8:27:46 AM:

1/31:97 - 8:32:01 AM:

1/31/97 - 8:32:01 AM: START OF LLCECALC

1/31/97 - 8:32:02 AM:

1/31/97 - 8:32:03 AM: LLCE Data File Selected: cillcedataitestedf

1/31/97 - 8:32:03 AM: Gamma File Data Present in LLCE Data File

1/31/97 - 8:32:04 AM:

1/31/97 - 8:32:08 AM: START - Analysis of LLCE Waste Characterization

1/31/97 - 8:32:08 AM:

1/31/97 - 8:32:09 AM: START - Calculate Radiochemical/Chemical Content of LCE Waste

1/31/97 - 8:32:09 AM: Converting mass units to grams and curies

1/31/97-8:32:10 AM: Cleared out old calcs (if any)

1/31/97 - 8:32:11 AM: Estimating the Content of each Radiochemical/Chemical in LLCE waste

1/31/97 - 8:32:14 AM: END - Calculate Radiochemical/Chemical Content of LLCE Waste

1/31/97 - 8:32:14 AM:

1/31/97 - 8:32:15 AM: START - Calculate to see if SARP Limits are exceeded.

1/31/97 - 8:32:17 AM: No SARP Limits have been exceeded.

1/31/97 - 8:32:17 AM: SEP is not required for this waste package

1/31/97 - 8:32:18 AM: END - Calculate to sec if SARP Limits are exceeded.

1/31:97 - 8:32:18 AM:

1/31/97 - 8:32:19 AM: START - Calculate for Cat 1 and Cak $3 \mathrm{LLW}$

1/31/97 - 8:32-20 AM: Volume for LLCE waste container: $S$ is 2.7028et 1 ta`3

1/31/97 - 8:32:22 AM: Cat 1 Sum of fractions is : 3.5736e-1

1/31/97 - 8:32:22 AM: Cat 3 Sum of fractions is : 7.3316e-7

1/31/97 - 8:32:23 AM: NRC Class C Sum of fractions is : $4.2747 \mathrm{e}-7$

1/31/97 - 8:32:24 AM: Cat 3 Noncombustable Limit Sum of fractions is : 1.2015e-7

1/31/97 - 8:32:25 AM: LLCCE waste is Category I, LLMW

1/31/97 - 8:32:25 AM: LLCE is suitable for near surfuce disposal (NRC C Fraction <1)

1/31/97 - 8:32:26 AM: Additional safety analysis is not required for near surface disposal. (NonComb Fraction <1)

1/31/97 - 8:32:27 AM: END - Calculate for Cat 1 and Cat $3 \mathrm{LLW}$

1/31/97 - 8:32:27 AM:

1/31/97 - 8:32:28 AM: START - Calculate for TRU

1/31/97 - 8:32:49 AM: LLCE Weight is $2 . e+3 \mathrm{~kg}$.

1/31/97 - 8:32:52 AM: LLCE waste is Low Level Mixed Waste (LLMW) since TRU fraction <1 (6.1617e-5)

1/31/97 - 8:32:53 AM: LLCE waste in not Greater than NRC Class C since NRC fraction <1 (6.1617e-5)

1/31/97 - 8:32:53 AM: END - Calculate for TRU

1/31/97 - 8:32:54 AM:

1/31/97 - 8:32:55 AM: START - Calculate PE-Ci for TRU waste

1/31/97 - 8:32:56 AM: Since LLCE waste is not JRU this calculation is not required.

1/31/97 - 8:32:56 AM: END - Calculate PE-Ci for TRU wastc

1/31/97 - 8:32:57 AM:

1/31/97 - 8:32:58 AM: START - Calculate Pu-239 FGE for TRU waste

1/31/97 - 8:32:59 AM: Since LLCE waste is not TRU this calculation is not required.

1/3197 - 8:32:59 AM: END - Calculate PU-239 FGE for TRU waste

1/31/97 - 8:33:00 AM:

1/31/97 - 8:33:01 AM: START - Calculate Alpha Curie Content for TRU weste

1/31/97 - 8:33:02 AM: Since LICE waste is not TRU this calculation is not required.

1/31/97 - 8:33:02 AM: END - Calculate Alphe Curie.Content for TRU waste

1/31/97-8:33:03 AM:

1/3197 - 8:33:04 AM: START - Calculate for Accountable Nuclear Material

1/3197 - 8:33:05 AY: LLCE waste does not contain accountable nuclear material.

1/3 L/97 - 8:33:06 AM: END - Caiculate for Accountable Nucleat Material

1/31/97 - 8:33:06 AM:

1/31/97 - 8:33:07 AM: START - Calculate heat generation rate of LLCE waste package

1/31/97 - 8:33:09 AM: Total heat generated by LLCE waste is: 1.648 le-3 watts.

$1 / 31 / 97$ - 8:33:10 AM: Internal Volume of selected Container LICE-5 = 9.5449 +2 fM-3

1/31/97 - 8:33:10 AM: Heat Generation rate for this LLCE weste is 1.7267e-6 watts/f 3

1/31/97 - 8:33:11 AM: Heat Generation rate doesn't exceed 0.1 watts/An'3

1/31/97 - 8:33:12 AM: END - Calculate heat generation rate of LLCE waste package

$1 / 31 / 97$ - 8:33:12 AM:

I/3L/97 - 8:33:13 AM: START - Calculate Transportation Category

I/31/97 - 8:33:15 AM: A2 Fraction Sum = 1.7856e-2

1/31/97 - 8:33:16 AM: EP-0063 Appendix L A2 Limit Fraction $=2.3206 \mathrm{e}-2$ 
1/31/97 - 8:33:16 AM: LLCE Weste Package is Type A Quantity.

1/31/97 - 8:33:17 AM: DE-Ci Calculation is not required.

I/31/97 - 8:33:18 AM: END- Calculate Transportation Category

1/31/97 - 8:33:18 AM:

1/31/97 - 8:33:19 AM: START - Calculate DE-Ci

1/31/97 - 8:33:20 AM: DE-Ci Calculation is not required according to transportation category.

1/31/97 - 8:33:21 AM: START - Caleulate Hazardous Waste Codes

1/31/97 - 8:33:22 AM: Heardous waste codes F001-F005 apply to all LLCE.

1/31/97 - 8:33:23 AM: No other Waste codes Apply.

1/31/97 - 8:33:24 AM: END - Calculate Hazandous Waste Codes

$1 / 31 / 97$ - 8:33:24 AM:

1/31/97 - 8:37:00 AM:

1/31/97 - 8:37:00 AM: START OF LLCECALC

1/31/97 - 8:37:01 AM:

1/31/97 - 8:37:01 AM: LLCE Data Fitle Selected: c:Ulcedataltestedf

1/31/97 - 8:37:02 AM: Gamma File Data Present in LLCE Data File

1/31/97 - 8:37:03 AM:

1/31/97 - 8:37:06 AM: START - Analysis of LLCE Waste Charactetization

1/31/97 - 8:37:07 AM:

1/31/97 - 8:37:07 AM: START - Calćulate Radiochenicat/Chemical Content of LLCE Waste

1/31/97 - 8:37:08 AM: Converting mass units to grams and curies

1/31/97 - 8:37:09 AM: Cleared out old calcs (if any)

1/31/97 - 8:37:10 AM: Estimating the Content of each Radiochemical/Chemical in LLCE waste

1/31/97 - 8:37:13 AM: END - Calculate Radlochemical/Chemical Content of LLCE Waste

1/31/97 - 8:37:13 AM:

1/31/97 - 8:37:14 AM: START - Calculate to see if SARP Limits are exceeded.

1/31/97 - 8:37:16 AM: No SARP Limits have been exceeded.

1/31/97 - 8:37:16 AM: SEP is not required for this waste package

1/31/97 - 8:37:17 AM: END - Calculate to see if SARP Limits are exceeded.

1/31/97 - 8:37:18 AM:

1/3197 - 8:37:18 AM: START - Calculate for Cat 1 and Cat 3 LLW

1/31/97 + 8:37:19 AM: Volume for LLCE waste container: $S$ is $2.7028 \mathrm{e}+1 \mathrm{~m}^{\wedge} 3$

1/31/97 - 8:37:21 AM: Cat 1 Sum of fractions is : $3.5736 \mathrm{e}-1$

1/31/97 - 8:37:22 AM: Cat 3 Sum of fractions is : 7.3316e-7

$1 / 1 / 97$ - 8:37:23 AM: NRC Class C Sum of fractions is : 4.2747e-7

1/3 L/97 - 8:37:23 AM: Cat 3 Norcombustable Limit Sum of fractions is : 1.2015e-7

1/31/97 - 8:37:24 AM: LLCE waste is Caregory 1, LLMW

1/31/97 - 8:37:25 AM: LLCE is suitable for near surface disposal (NRC C Fraction < 1)

1/31/97 - 8:37:26 AM: Additional safety analysis is not requived for near surface disposal. (NonComb Fraction <1)

1/31/97 - 8:37:27 AM: END - Calculate for Cat 1 and Cat $3 \mathrm{LLW}$

1/31/97 - 8:37:27 AM:

1/31/97 - 8:37:28 AM: START - Calculate for TRU

$1 / 31 / 97-8: 37: 33$ AM: LLCE Weight is $2.0+3 \mathrm{~kg}$.

1/31/97 - 8:37:35 AM: LLCE waste is Low Level Mixed Waste (LLMW) since TRU fraction <1 (6.1617c-5)

1/31/97 - 8:37:36 AM: LLCE wasle in not Greates than NRC Class C since NRC fraction <1 (6.1617e-5)

1/31/97 - 8:37:37 AM: END - Calculate for TRU

1/31/97 - 8:37:38 AM:

1/31/97 - 8:37:38 AM: START - Calculate PE-Ci for TRU waste

1/31/97 - 8:37:39 AM: Since LLCE waste is not TRU this calculation is not required.

1/31/97 - 8:37:40 AM: END - Calculate PE-Ci for TRU weste

1/31/97 - 8:37:41 AM:

1/31/97 - 8:37:41 AM: START - Calculate Pu-239 FGE for TRU waste

1/31/97 - 8:37:42 AM: Since LLCE waste is not TRU this calculation is not required.

1/31/97 - 8:37:43 AM: END - Caleulate PL-239 FGE for TRU w8ste

1/31/97 - 8:37:44 AM:

1/31/97 - 8:37:45 AM: START - Calculate Alpha Curie Content for TRU waste

1/31/97 - 8:37:46 AM: Since LICE waste is not TRU this calculatton is not required.

1/31/97 - 8:37:46 AM: END - Calculate Alpha Curie Content for TRU waste

1/31/97 - 8:37:47 AM:

1/31/97 - 8:37:48 AM: START - Calculate for Accountmble Nuclear Material

1/31/97 - 8:37:49 AM: LLCE waste does not contain accountable nuclear materia!.

1/31/97 - 8:37:50 AM: END - Celculate for Accountable Nuclear Material

1B1/97 - 8:37:51 AM:

1/31/97 - 8:37:51 AM: START - Celculate heas gencration rate of LLCE waste package

1/31/97 - 8:37:53 AM: Total heat generated by LLCE waste is: 1.6481e-3 watts.

1/31/97 - 8:37:54 AM: Intemal Volume of selected Container LLCE-5 $=9.54490+2 \mathrm{ft}^{\wedge} 3$

131/97 - 8:37:55 AM: Heat Gemeration rate for this LICE waste is 1.7267e-6 watts/ft'3

1/31/97 - 8:37:56 AM: Heat Generation rate doesn't exceed 0.1 watss/ti³

i/31/97 - 8:37:57 AM: END - Calculate heat generation rate of LLCE waste package

1/31/97 - 8:37:57 AM:

1/31/97 - 8:37:58 AM: START - Calculate Transportation Category 
1/31/97 - 8:38:00 AM: A2 Fruction Sum - 1.7856e-2

1/31/97 - 8:38:01 AM: EP-0063 Apperdix L A2 Limit Fraction $=2.32060-2$

1/3197 - 8:38:01 AM: LLCE Waste Package is Type A Quantity.

1/31/97 - 8:38:02 AM: DE-Ci Calculation is not required.

1/31/97 - 8:38:03 AM: END- Calculate Transportation Category

1/31/97 - 8:38:03 AM:

1/31/97 - 8:38:04 AM: START - Calculate DE-Ci

1/31/97 - 8:38:05 AM: DE-Cj Calculation is not required according to transportation category.

1/31/97 - 8:38:06 AM: START - Calculate Hazardous Wasto Codes

1/31/97 - 8:38:07 AM: Hacardous waste codes F001-F005 apply to all LLCE.

1/31/97 - 8:38:08 AM: No other Waste codes Apply.

1/31/97 - 8:38:09 AM: END - Calculate Hezardous Waste Codes

1/31/97 - 8:38:10 AM:

1/31/97 - 9:11:26 AM:

1/31/97 - 9:11:26 AM: START OF LLCECALC

131/97 - 9:11:26 AM:

1/31/97 - 9:1 1:27 AM: LLCE Data File Selectod: cildriveellicecalclsteve.edf

1/31/97 - 9:11:27 AM: Gamuns File Data Present in LLCE Data File

1/31/97 - 9:11:27 AM:

1/31/97 - 9:1 t:29 AM: START - Analysis of LLCE Waste Characterization

1/31/97-9:11:29 AM:

1/31/97 - 9:1 1:29 AM: START - Calculate Radiochemical/Chemical Content of LLCE Waste

1/31/97 - 9:11:29 AM: Converting mass units to grams and curies

1/3197 - 9:11:29 AM: Cleared out old cales (if any)

1/31/97 - 9:11:29 AM: Estimating the Content of each Radiochemicat/Chemical in LLCE waste

1/31/97 - 9:11:30 AM: END - Calculate Radiochemical/Chemical Content of LLCE Waste

1/31/97 - 9:11:30 AM:

1/31/97 - 9:11:30 AM: START - Calculate to see if SARP Limits are exceted.

131/97 - 9:11:31 AM: No SARP Limits have been exceeded.

1/31/97 - 9:11:31 AM: SEP is not required for this waste package

1/31/97 - 9:1 1:31 AM: END - Calculate to see if SARP Limits are exceeded.

1/31/97 - 9:11:31 AM:

1/31/97-9:11:32 AM: START - Caleulate for Cat J and Cat $3 \mathrm{LLW}$

1/31/97 - 9:11:32 AM: Volume for LLCE waste container: 5 is $2.7028 \mathrm{e}+1 \mathrm{~m}^{\wedge} \mathrm{s}$

131/97 - 9:11:32 AM: Cat 1 Sum of fractions is : $3.5736 \mathrm{e}-1$

1/31/97 - 9:11:32 AM: Cat 3 Sum of fractions is : 7.3316e-7

1/31/97 -9:11:33 AM: NRC Class C Sum of fractions is : $4.2747 e-7$

1/31/97 -9:11:33 AM: Cat 3 Noncombustable Limit Surr of fractions is : 1.2015e-7

1/31/97 - 9:1 1:33 AM: LLCE waste is Category 1, LLMW

1/31/97 - 9:11:33 AM; LLCE is suitable for near surface disposal (NRC C Fraction <1)

131/97 - 9:11:33 AM: Additional safety analysis is not required for near surface disposal. (NonComb Fraction $<1$ )

U31/97-9:11:34 AM: END - Calculate for Cat I and Cat 3 LLW

1/31/97 - 9:11:34 AM:

1/31/97 - 9:11:34 AM: START - Calculate for TRU

1/31/97 - 9:11:44 AM: LLCE Weight is $1 . e+3 \mathrm{~kg}$.

1/31/97 - 9:11:45 AM: LLCE waste. is Low Level Mixed Waste (LLMW) since TRU fraction <1 (1.2323e-4)

1/31/97 - 9:11:45 AM: LLCE waste in not Greater than NRC Class C since NRC fraction <1 (1.2323e-4)

1/31/97-9:11:45 AM: END - Calculate for TRU

1/31/97-9:11:46 AM:

1/31/97 - 9:11:46 AM: START - Calculate PE-Ci for TRU waste

1/31/97-9:11:46 AM: Since LLCE waste is not TRU this calculation is not required.

1/31/97 -9:11:46 AM: END - Calculate PE-Ci for TRU waste

1/31/97 - 9:11:46 AM:

1/31/97 - 9:11:47 AM: START - Calculate PU-239 FGE for TRU waste

1/3197 - 9:11:47 AM: Since LLCE waste is not TRU this calculation is not required.

1/3197 - 9:11:47 AM: END - Calculate Pu-239 FGE for TRU waste

1/31/97 - 9:11:47 AM:

1/31/97 - 9:11:47 AM: START - Calculatc Alpha Curie Content for TRU waste

1/31/97 - 9:11:48 AM: Since LLCE waste is not TRU this calculation is not required.

1/31/97 - 9:1 1:48 AM: END - Calculate Alpha Cutie Content for TRU waste

1/31/97 - 9:11:48 AM:

1/31/97 - 9:1 1:48 AM: START - Calculate for Accountable Nuclear Material

1/31/97 - 9:1 1:49 AM: LLCE waste does not contain accountable nuelesr material.

1/31/97 - 9:11:49 AM: END - Calculare for Accountable Nuclesr Material

1/31/97 - 9:11:49 AM:

1/31/97-9:11:49 AM: START - Calculate heat generation rate of LLCE waste package

1/31/97 - 9:11:50 AM: Total heat generated by LLCE waste is: $1.6481 \mathrm{e}-3$ watts.

1/31/97 - 9:1 1:50 AM: Intemal Volume of selected Container LLCE-S $=9.5449+2+3$

1/31/97 - 9:11:50 AM: Heat Generation rate for this LLCE waste is 1.7267e-6 watts/ $\mathrm{t}^{\wedge} 3$

1/31/97 - 9:11:50 AM: Heat Generation rate doesn't exceed 0.I watts/f^3

1/31/97 - 9:11:50 AM: END - Calculate heat generation rate of LLCE wasto package 
1/3197 - 9:11:51 AM:

1/3I/97 - 9:11:51 AM: START - Calculgte Transportation Category

1/31/97 - 9:1 1:51 AM: A2 Fraction Sun $=1.78560-2$

1/31/97 - 9:11:51 AM: EP-0063 Appendix L A2 Limit Fraction $=2.3206 e-2$

[3:197 - 9:11:52 AM: LLCE Waste Package is Type A Quantity.

1/31/97-9:11:52 AM: DE-Ci Calculation is not required.

131/97 - 9:11:52 AM: END-Calculate Transportation Category

1/31/97 - 9:11:52 AM:

1/31/97 - 9:11:52 AM: START - Calculate DE-Ci

1/31/97 - 9:11;53 AM; DE-Cl Calculation is not required according to transpontation carcigory. 1/31/97 - 9:11:53 AM: START - Calculate Hazerdous Waste Codes

1/31/97 - 9:11:53 AM: Hazardous waste codes F001-F005 apply to all LLCE.

1/31/97 -9:11:53 AM: No other Waste codes Apply.

1/31/97 - 9:11:53 AM: END - Calculate Hazardous Waste Codes

13197-9:11:54 AM: 
DISTRIBUTION SHEET

\begin{tabular}{|c|c|c|c|c|c|}
\hline \multirow{2}{*}{$\begin{array}{l}\text { To } \\
\text { Distribution }\end{array}$} & \multirow{2}{*}{\multicolumn{3}{|c|}{$\begin{array}{l}\text { From } \\
\text { Packaging Engineering }\end{array}$}} & \multicolumn{2}{|c|}{ Page 1 of 1} \\
\hline & & & & \multicolumn{2}{|c|}{ Date Sept. 28, 1998} \\
\hline \multicolumn{4}{|l|}{ Project Title/Work Order } & \multicolumn{2}{|c|}{ EDT No. $N / A$. } \\
\hline \multicolumn{4}{|c|}{$\begin{array}{l}\text { Long-Length Contaminated Equipment Disposal Process Path } \\
\text { Document (HNF-SD-WM-ER-730, Rev. 1) }\end{array}$} & \multicolumn{2}{|c|}{ ECN No. 646729} \\
\hline Name & MSIN & $\begin{array}{l}\text { Text } \\
\text { With All } \\
\text { Attach. }\end{array}$ & Text Only & $\begin{array}{l}\text { Attach./ } \\
\text { Appendix } \\
\text { Only }\end{array}$ & $\begin{array}{l}\text { EDT/ECN } \\
\text { Only }\end{array}$ \\
\hline $\begin{array}{l}\text { R. M. Boger } \\
\text { D. W. Crass } \\
\text { C. DeFigh-Price } \\
\text { J. G. Field } \\
\text { W. H. Grams } \\
\text { G. P. Janicek } \\
\text { D. E. Legare } \\
\text { W. A. McCormick } \\
\text { R. J. Smith }\end{array}$ & $\begin{array}{l}S 7-12 \\
R 3-47 \\
S 7-21 \\
H 1-15 \\
R 1-49 \\
S 7-12 \\
R 3-47 \\
H 1-15 \\
H 1-15\end{array}$ & $\begin{array}{l}x \\
X \\
X \\
X \\
X \\
x \\
x \\
x \\
X \\
x\end{array}$ & . & . & . \\
\hline HNF-SD-WM-ER-730 File & $\mathrm{H} 1-15$ & $x$ & & & \\
\hline $\begin{array}{l}\text { Central Files } \\
\text { DOE/RL Reading Room } \\
\text { Hanford Technical Library }\end{array}$ & $\begin{array}{l}B 1-07 \\
H 2-53 \\
P 8-55\end{array}$ & $\begin{array}{l}x \\
x \\
x\end{array}$ & & & \\
\hline
\end{tabular}

